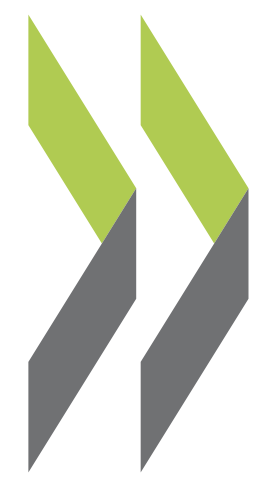

OECD Economics Department Working Papers No. 1414

Boosting productivity

for inclusive growth in Japan

\section{Randall Jones,}

Yosuke Jin 
Organisation de Coopération et de Développement Économiques

Organisation for Economic Co-operation and Development

02-Oct-2017

ECONOMICS DEPARTMENT

English - Or. English

BOOSTING PRODUCTIVITY FOR INCLUSIVE GROWTH IN JAPAN

ECONOMICS DEPARTMENT WORKING PAPERS No. 1414

By Randall S. Jones and Yosuke Jin

OECD Working Papers should not be reported as representing the official views of the OECD or of its member countries. The opinions expressed and arguments employed are those of the author(s).

Authorised for publication by Alvaro Pereira, Director, Country Studies Branch, Economics Department.

All Economics Department Working Papers are available at www.oecd.org/eco/workingpapers.

Complete document available on OLIS in its original format

This document, as well as any data and map included herein, are without prejudice to the status of or sovereignty over any territory, to the delimitation of international frontiers and boundaries and to the name of any territory, city or area. 
OECD Working Papers should not be reported as representing the official views of the OECD or of its member countries. The opinions expressed and arguments employed are those of the author(s).

Working Papers describe preliminary results or research in progress by the author(s) and are published to stimulate discussion on a broad range of issues on which the OECD works.

Comments on Working Papers are welcomed, and may be sent to the Economics Department, OECD, 2 rue André-Pascal, 75775 Paris Cedex 16, France, or by e-mail to econ.contact@ oecd.org.

All Economics Department Working Papers are available at www.oecd.org/eco/workingpapers.

This document and any map included herein are without prejudice to the status of or sovereignty over any territory, to the delimitation of international frontiers and boundaries and to the name of any territory, city or area.

The statistical data for Israel are supplied by and under the responsibility of the relevant Israeli authorities. The use of such data by the OECD is without prejudice to the status of the Golan Heights, East Jerusalem and Israeli settlements in the West Bank under the terms of international law.

You can copy, download or print OECD content for your own use, and you can include excerpts from OECD publications, databases and multimedia products in your own documents, presentations, blogs, websites and teaching materials, provided that suitable acknowledgment of OECD as source and copyright owner is given. All requests for commercial use and translation rights should be submitted to rights@oecd.org 


\section{ABSTRACT/RÉSUMÉ \\ Boosting productivity for inclusive growth in Japan}

Never in the past 30 years has productivity growth been lower than since the 2008 global financial crisis, and never has income inequality been higher than it is today in Japan, and in the OECD area. The two challenges have some common origins, including a widening productivity and wage gap between leading firms and those that are lagging. This creates scope for positive synergy between policies to promote productivity and inclusive growth. Exit policy should be improved to facilitate the closure of non-viable firms, whose survival hampers the growth of viable firms in Japan. This would also increase firm entry, along with policies to promote entrepreneurship. The growing gap between small and medium-sized enterprises and large firms also needs to be addressed. Breaking down labour market dualism, which limits human capital accumulation by non-regular workers and contributes to earnings and income inequality, is also a priority. Finally, ensuring appropriate skills, including those needed for digitalisation, would help support higher productivity and inclusive growth.

This Working Paper relates to the 2017 OECD Economic Survey of Japan (www.oecd.org/eco/surveys/economic-survey-japan.htm)

JEL classification: K3, J4, O3, O4

Keywords: Abenomics, productivity, income inequality, firm exit, bankruptcy law, entrepreneurship, product market regulation, corporate governance, innovation, SMEs, labour market dualism, human capital

***********************************

\section{Stimuler la productivité pour une croissance inclusive au Japon}

La croissance de la productivité n'a jamais été aussi faible que depuis la crise financière mondiale de 2008 et les inégalités de revenu n'ont jamais été aussi marquées qu'aujourd'hui au Japon, mais aussi dans l'OCDE. Ces deux problématiques s'enracinent dans un terreau commun, et notamment dans un écart de productivité et de salaires qui va croissant entre les entreprises en pointe et celles qui sont à la traîne. Des synergies positives sont donc possibles entre les politiques publiques de promotion de la productivité et de la croissance inclusive. Il conviendrait de faciliter les sorties d'entreprises pour accélérer la fermeture de celles qui ne sont pas viables et dont la survie gêne l'expansion de celles qui le sont. Accompagnée de mesures de promotion de l'entrepreneuriat, l'arrivée de nouvelles entreprises s'en trouverait facilitée. Il faudrait également aborder la question du fossé croissant entre PME et grandes entreprises. De même, la rupture avec le dualisme du marché du travail, qui limite l'accumulation de capital humain chez les travailleurs non réguliers et concourt aux inégalités de rémunération, est une priorité. Enfin, veiller à l'acquisition de compétences adéquates, y compris de celles indispensables à l'ère du numérique, aiderait à atteindre l'objectif d'un accroissement de la productivité et d'une croissance inclusive.

Ce Document de travail a trait à l'Étude économique de l'OCDE du Japon, 2017

(http://www.oecd.org/fr/eco/etudes/etude-economique-japon.htm).

Classification JEL : K3, J4, O3, O4

Mots clés : Abenomics, productivité, inégalités de revenu, sortie d'activité, loi sur la faillite, entrepreneuriat, réglementation des marchés de produits, gouvernance d'entreprise, innovation, PME, dualisme du marché du travail, capital humain 


\section{TABLE OF CONTENTS}

The common origins of the productivity and income inequality challenges .........................................

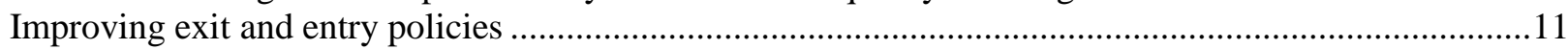

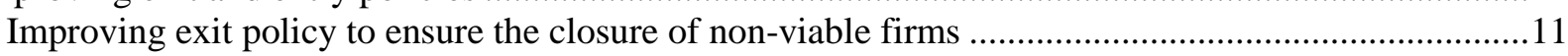

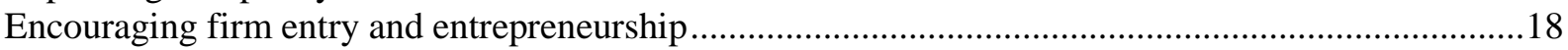

Other policies to promote synergy between higher productivity and inclusive growth............................22

Product market reform to promote entrepreneurship and innovation.................................................22

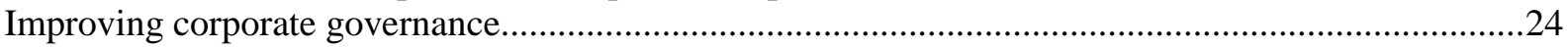

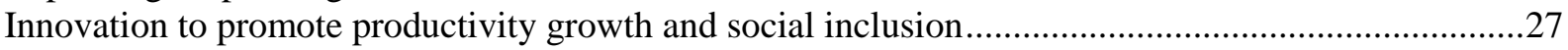

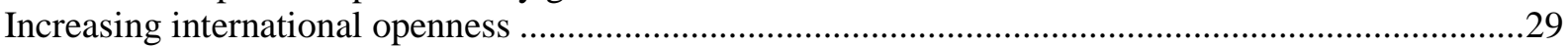

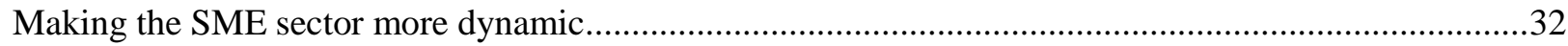

Directions for reform to improve government programmes for SMEs .................................................35

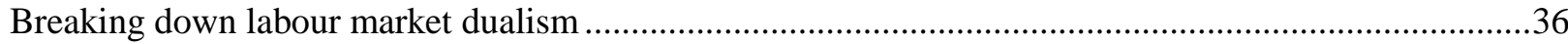

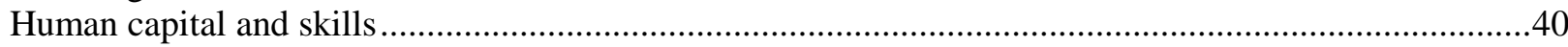

Ensuring that digitalisation promotes inclusive growth ..................................................................

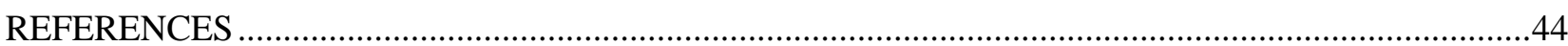

\section{Tables}

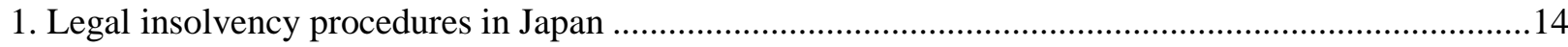

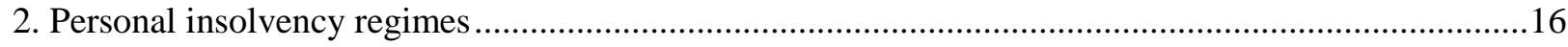

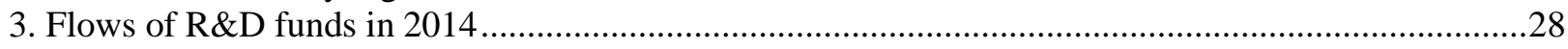

4. Non-regular worker households suffer from a high poverty rate .......................................................38

5. Investment in Information and Communication Technology is low in small firms .............................42

\section{Figures}

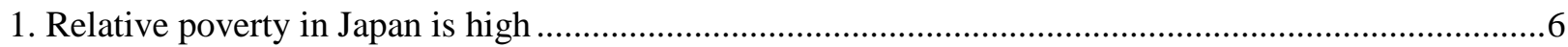

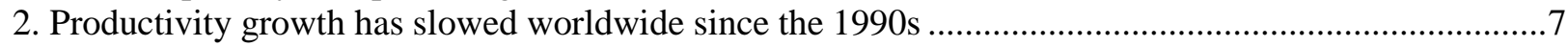

3. Labour productivity in Japan remains about a quarter below the top half of OECD countries ................8

4. The labour productivity gap between global frontier firms and other firms is widening ......................9

5. Productivity in Japanese firms has diverged significantly ..............................................................10

6. Labour income inequality is positively correlated with productivity disparities between firms ............10

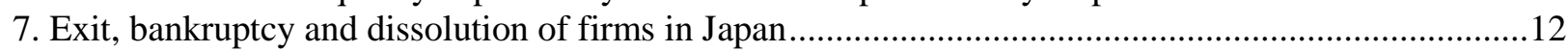

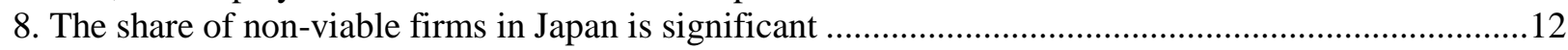

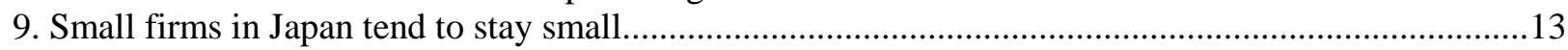

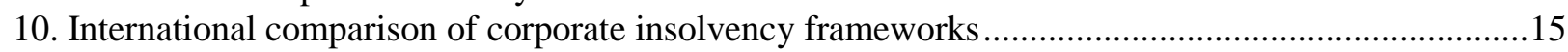

11. Japan's annual firm entry rate is lower than in other advanced economies ......................................18

12. The share of entrepreneurs in Japan is low, especially among women.............................................19

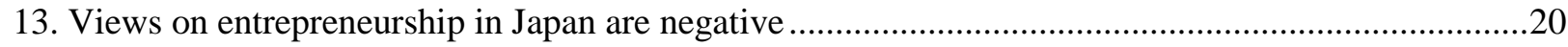

14. Access to entrepreneurial training and finance is relatively low in Japan, especially for women .......21

15. The venture capital sector is relatively undeveloped in Japan ........................................................21

16. There is scope to align Japan's product market regulation with OECD best practice..........................23

17. Share of institutional investors complying with the Stewardship Code's principles...........................25 
18. The share of companies with independent directors has increased rapidly ......................................26

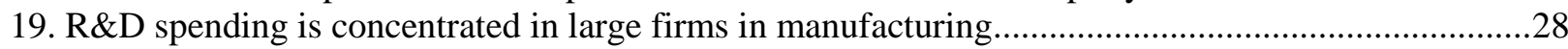

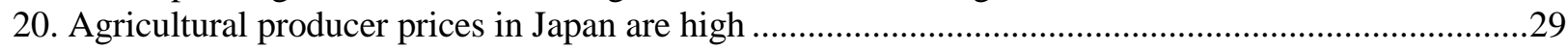

21. Japan's farm workforce is elderly: the age distribution of rice farmers in 2015 ..............................31

22. The level of foreign direct investment in Japan remains low ..........................................................32

23. Productivity in small firms in Japan is low relative to large firms ....................................................33

24. The productivity gap between manufacturing and non-manufacturing has widened sharply...............33

25. Public credit guarantees for loans to small and medium-sized enterprises have fallen significantly ..34

26. Credit guarantees for small and medium-sized enterprises in Japan are exceptionally high ................35

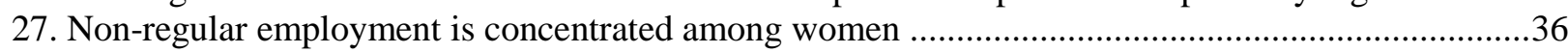

28. The wage gap between regular and non-regular workers is large ..................................................... 37

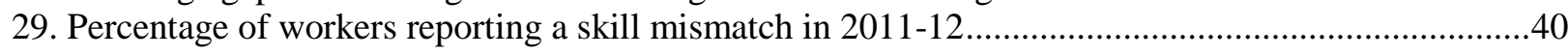

30. Japan is lagging in the share of firms with broadband connectivity ...............................................41

\section{Boxes}

Box 1. Main policy recommendations for boosting productivity for inclusive growth 


\title{
BOOSTING PRODUCTIVITY FOR INCLUSIVE GROWTH IN JAPAN
}

\author{
By Randall S. Jones and Yosuke Jin ${ }^{l}$
}

Japan, along with many OECD countries, has experienced an increase in income inequality and relative poverty during the past 30 years. Japan's relative poverty rate increased from $12.0 \%$ in 1985 to $16.1 \%$ in 2012, making it the seventh highest in the OECD (Figure 1), reflecting the weak impact of its tax and benefit system, which primarily redistributes income between rather than within generations. Japan's share of households in relative poverty despite having two or more workers is the second highest in the OECD. Moreover, conditions have deteriorated in absolute terms for those in relative poverty: the "relative poverty line" $-50 \%$ of the national median income - has fallen by 15\% in real terms since 1997 (Oshio, 2013).

Figure 1. Relative poverty in Japan has risen to a high level

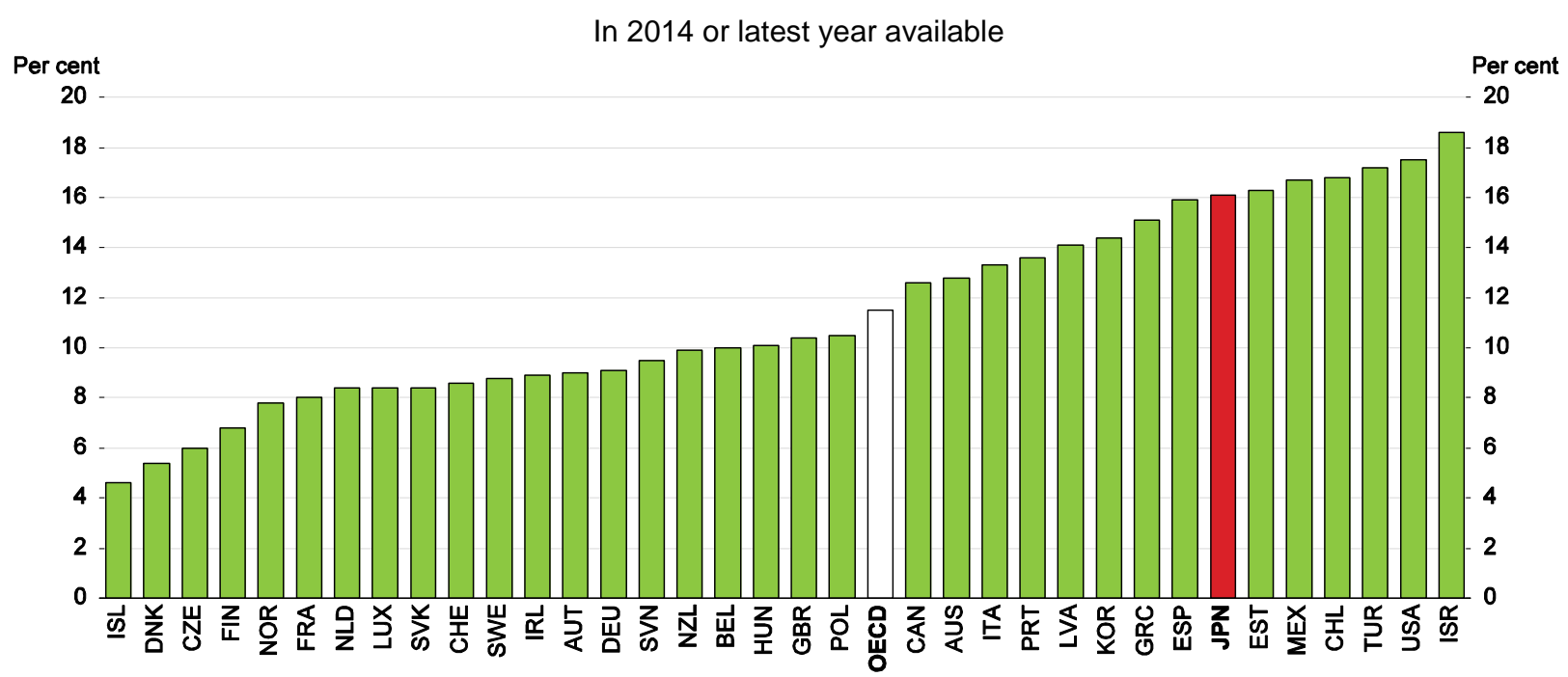

Note:The share of the population with an income less than half of the "median equivalent disposable income" (adjusted for household size). Values for Japan are based on the Comprehensive Survey of Living Conditions 2012. Another survey for Japan, the National Survey of Family Income and Expenditure, shows relative income poverty edging down from $10.1 \%$ in 2009 to $9.9 \%$ in 2014.

Source: OECD (2017d), OECD Income Distribution (database).

In addition, productivity growth in Japan, as in most OECD countries, has lost momentum (Figure 2). The deceleration in Japan is explained by shrinking contributions from both capital deepening (Panel B) and multifactor productivity (MFP) (Panel C). The impact of capital deepening - an increase in the amount of capital per worker - declined due to a sluggish rebound in business investment in Japan since the 2008 crisis, which has been held back in part by low growth prospects as population shrinks. By mid-2016, business investment finally regained its pre-crisis level. In contrast, it had risen by nearly $5 \%$ in the OECD area, which is still weaker than in past recoveries. In addition, the contribution of MFP, which reflects the efficiency with which inputs are used, has diminished, due to:

1. Randall S. Jones is head of the Japan/Korea Desk in the Economics Department of the OECD and Yosuke Jin is an economist on the Ireland/Portugal Desk. The authors would like to thank OECD Economics Department colleagues Muge Adalet McGowan, Dan Andrews, Andrew Barker, Robert Ford, Kohei Fukawa, Vincent Koen, Patrick Lenain, Valentine Millot and Alvaro Pereira, as well as Dirk Pilat (OECD Directorate for Science, Technology and Industry), Marco Mira d'Ercole (OECD Statistics Directorate), Michael Förster and Elena Tosetto (OECD Directorate for Employment and Social Affairs), Thomas Dannequin (OECD Directorate for Financial and Enterprise Affairs), Thomas Weko (OECD Directorate for Education and Skill) and officials from the Japanese government, for valuable comments and/or discussions. Special thanks go to OECD Economics Department colleagues Lutécia Daniel for technical assistance and Mercedes Burgos and Sisse Nielsen for technical preparation. 
- Declining business dynamism, as reflected in low start-up and exit rates (Criscuolo et al., 2014).

- Rising misallocation of resources, due in part to product and labour market regulations, which makes it difficult for productive firms to attract resources (Adalet McGowan et al., 2017).

- A widening divergence in productivity across firms, driven by stagnating productivity among laggard firms (Andrews et al., 2016).Figure 2. Productivity growth has slowed worldwide since the 1990s

Figure 2. Productivity growth has slowed worldwide since the $1980 \mathrm{~s}$

Total economy, percentage change at an annual rate

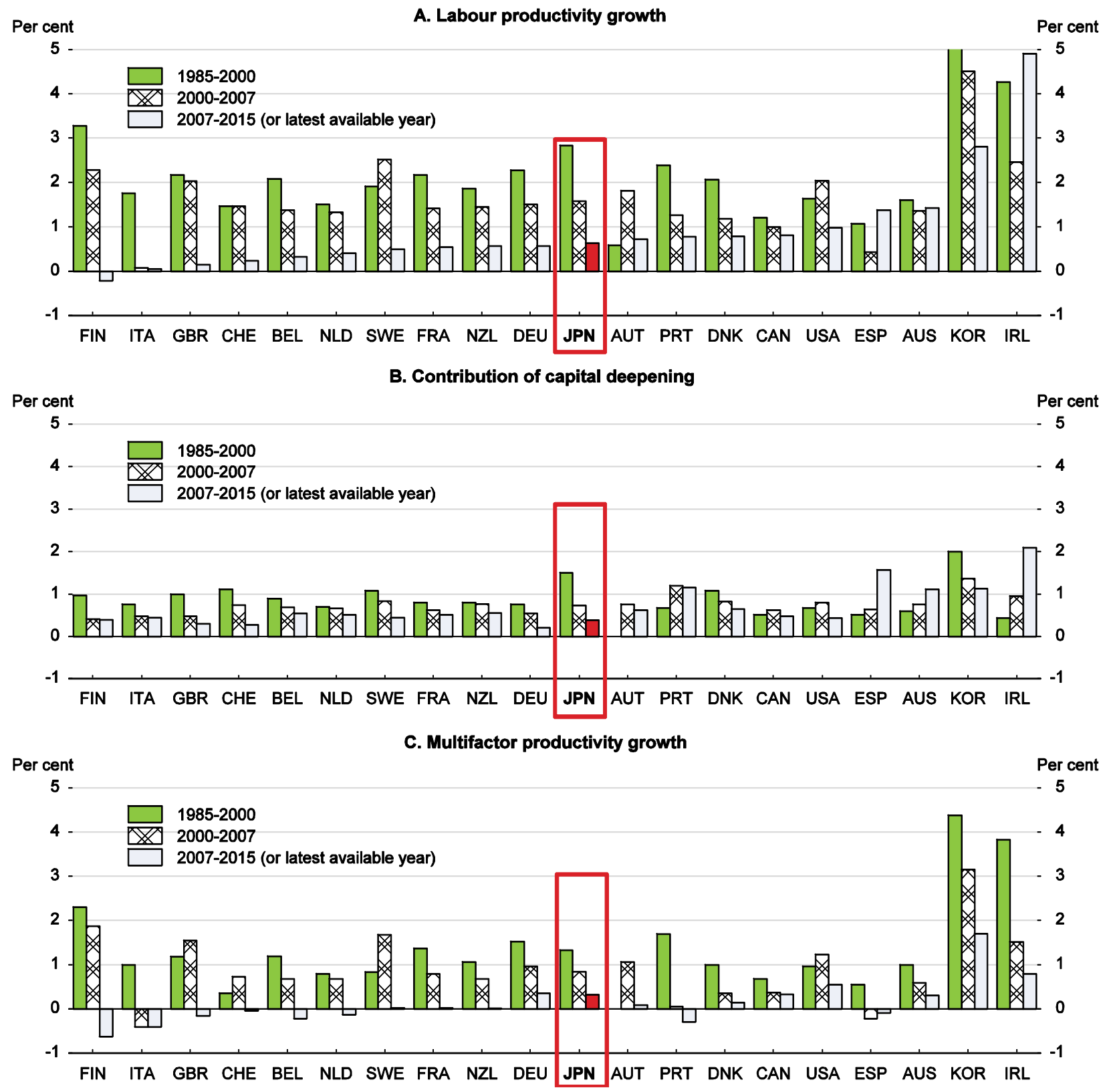

Source: OECD (2017g), OECD Productivity Statistics (database).

Labour productivity in Japan is a quarter below the top half of OECD countries (Figure 3), weighing down per capita income. In 2013, the government set a goal of boosting real output growth to an annual rate of $2 \%$ through 2022. Real growth has accelerated to an annual rate of $1.3 \%$ since the end of 2012 , 
significantly faster than Japan's potential growth rate of around $1 / 2$ per cent, though still well below the target. With the accelerating decline in the working-age population, achieving $2 \%$ output growth requires boosting labour productivity growth to more than $2 \%$, exceeding the rate during the $1990 \mathrm{~s}$. The government launched a plan in 2016 for promoting the dynamic engagement of all citizens, based on achieving a "virtuous cycle of growth and distribution". This requires broadening the productive base of the economy to generate strong and sustainable productivity gains that lead to inclusive growth and promoting the fair distribution of the dividends of increased prosperity across society.

This paper examines policies that can build on synergies between higher productivity and inclusive growth. It first discusses the links and common origins between the slowdown in productivity and the rise in inequality, including the widening gap between leading and lagging firms, which generates larger wage differences. The second section examines exit and entry policies to facilitate the exit of non-viable firms and the entry of innovative firms. The third section looks at other polices, such as product market regulation, which may help narrow productivity and wage gaps. The fourth section turns to measures to narrow the widening gap between SMEs and large firms. The fifth section addresses labour market dualism, which creates large wage gaps between regular and non-regular workers and limits human capital formation. The final section considers the issue of skills, particularly in the context of rapid digitalisation. Policy recommendations are presented in Box 1.

Figure 3. Labour productivity in Japan remains about a quarter below the top half of OECD countries ${ }^{1}$

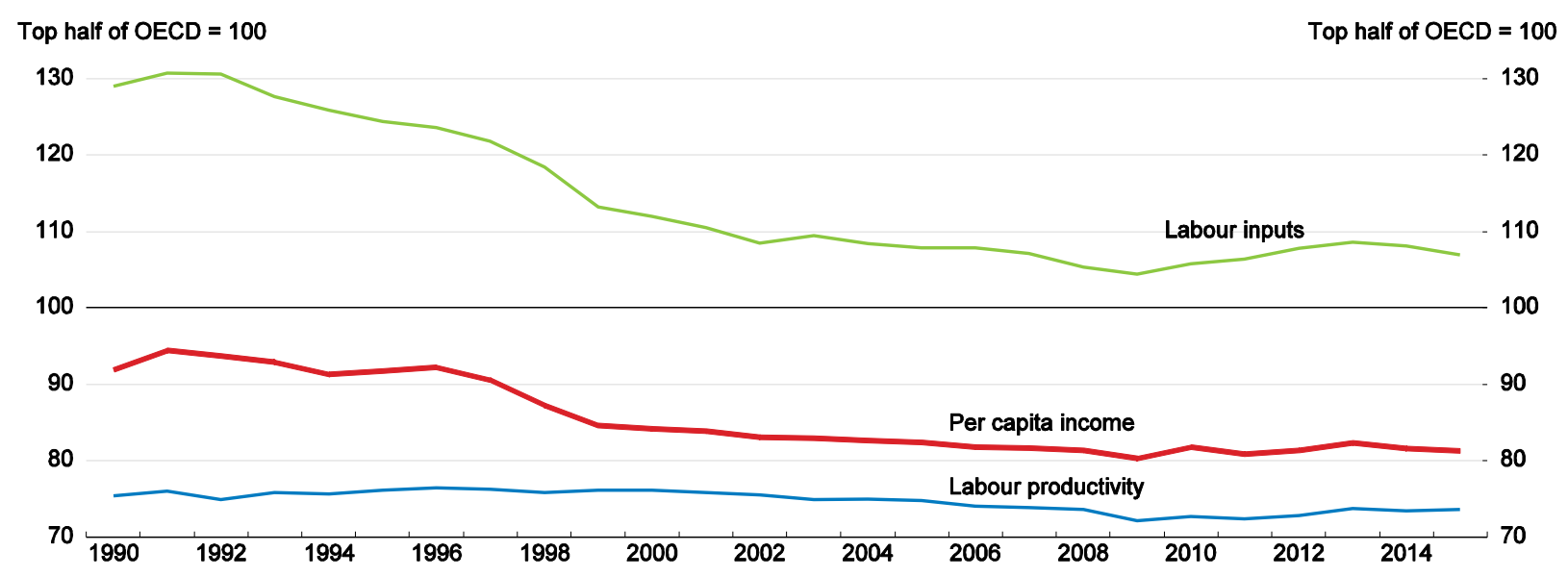

1. Per capita GDP is calculated using 2010 prices and PPP exchange rates. Labour productivity equals GDP per hour of labour input. Labour inputs equal the total number of hours worked per capita.

Source: OECD (2017b), OECD Economic Outlook Statistics and Projections (database).

\section{The common origins of the productivity and income inequality challenges}

Recent evidence from a number of countries suggests that much of the widening of the wage distribution across workers over the past two or three decades can be attributed to increases in the variance of wages between firms rather than within firms (Andrews et al., 2016). This is linked to increased dispersion in productivity in the world economy: firms at the global frontier have become relatively more productive, with their labour productivity rising at an average annual rate of $2.8 \%$ in manufacturing over 2001-13, compared to only $0.6 \%$ for non-frontier firms (Figure 4). The divergence is even more pronounced in market services. The widening gap may be attributable to several complementary factors: $i$ ) a decline in the diffusion of technology and knowledge from frontier firms to others; $i$ ) poorly-performing firms that remain longer in the market, rather than exiting, thereby trapping resources in unproductive activities; iii) a greater concentration of high-skilled workers in certain firms; and $i v$ ) greater concentration of market power and rent-seeking by frontier firms that may have left non-frontier firms behind. 
Figure 4. The labour productivity gap between global frontier firms and other firms is widening Labour productivity (value added per worker) in the world economy ${ }^{1}$

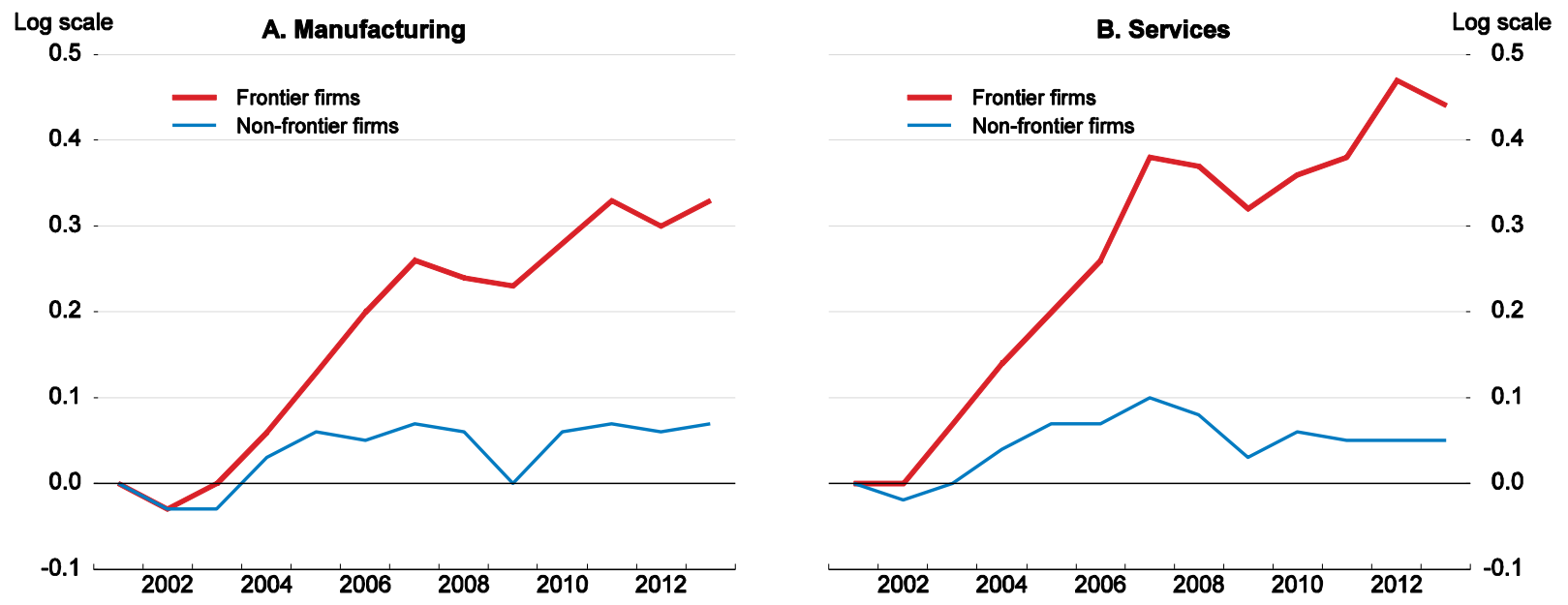

1. The global frontier is measured by the average of log labour productivity for the top $5 \%$ of companies in the world with the highest productivity levels within each 2-digit industry. Non-frontier firms are the average log productivity of all the other firms. Unweighted averages across 2-digit industries are shown for manufacturing and services, normalised to 0 in the starting year. Services refer to non-financial business services. The lines indicate cumulated growth rates. A value of 0.3 indicates a $30 \%$ increase, while -0.2 indicates a $20 \%$ decline. Source: Andrews et al. (2016).

Japan has also seen a divergence between firms in productivity, based on a study that covers nearly 26000 firms and 10.7 million workers each year over 1996-2011. The labour productivity gap between firms at the bottom decile, the fourth to sixth deciles and the top decile in the service sector, which accounts for nearly three-quarters of Japan's GDP, was quite stable until 1999 (Figure 5, Panel A). However, productivity levels have diverged significantly since then, even though firms with less than 50 workers are not covered in the survey. The divergence is even greater in terms of MFP (Panel B). In contrast to the global comparison (Figure 4), productivity has declined in most firms in Japan since 1995, including the leading firms.

Wider productivity gaps between firms tend to lead to greater wage inequality. Indeed, the dispersion between productivity in firms at the $90^{\text {th }}$ and $50^{\text {th }}$ percentiles in the OECD area is positively correlated with the dispersion in average wage income (Figure 6). For example, productivity and labour income gaps are relatively small in some northern European countries in contrast to some Eastern European countries. The dispersion of productivity in Japan is slightly above the OECD average and its dispersion of average labour income is far above it. This finding is confirmed by another study that compares wage levels in Japanese firms by quintiles of productivity (OECD, 2017i). Wage dispersion in the service sector has widened significantly since the late 1990s.

The impact of slowing productivity on wages is aggravated by the decoupling of growth in aggregate labour productivity and real median compensation in many countries. The labour share in Japan has fallen by about 6 percentage points over 1995-2014, the fifth-largest decline in the OECD, with most of it in services. The shrinking labour share is due in part to the rise in non-regular employment (see below). Consequently, raising productivity is no longer sufficient to raise real wages for the typical worker. Moreover, the ratio of the median wage to the average also declined in Japan (Schwellnus et al., 2017). 
Figure 5. Productivity in Japanese firms has diverged significantly
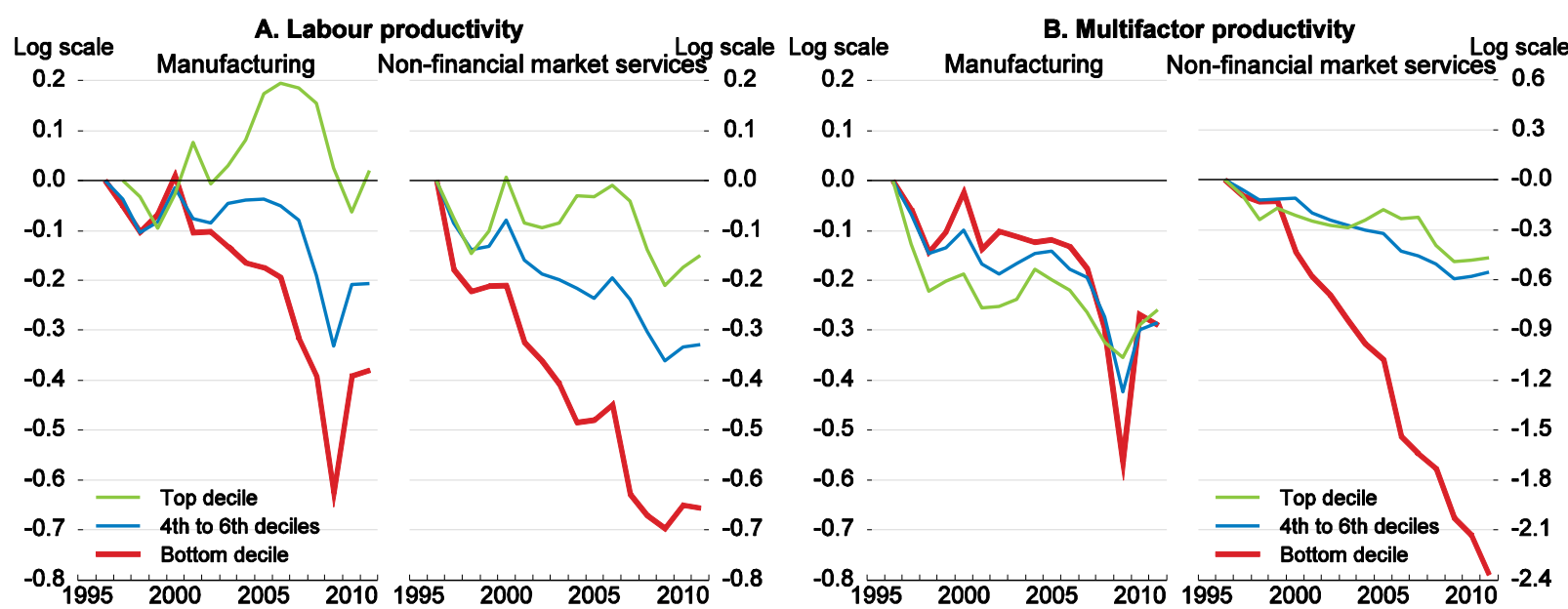

Note: The graph reports the unweighted average of real labour productivity (defined as real value added per employee) expressed in 2005 US dollars for firms in the bottom decile, between the $4^{\text {th }}$ and $6^{\text {th }}$ deciles, and in the top decile of the labour productivity distribution in any given year. The values are normalised at their initial values in 1996. The results differ from aggregate labour productivity as the 26000 firms are in two sectors and the sample excludes firms with less than 50 employees. A value of -0.2 indicates a $20 \%$ decline.

Source: OECD (2017i).

Another factor linking low productivity and income inequality is the difficulty faced by low-income groups in gaining access to high-quality education. The failure of certain groups to increase their human capital limits their income and slows aggregate productivity growth (OECD, 2016j). Fortunately, the Japanese school system achieves a high degree of equity in educational opportunities: the relationship between students' socio-economic status and performance is weaker than the OECD average and has remained stable since 2006 (OECD, 2016h).

Figure 6. Labour income inequality is positively correlated with productivity disparities between firms

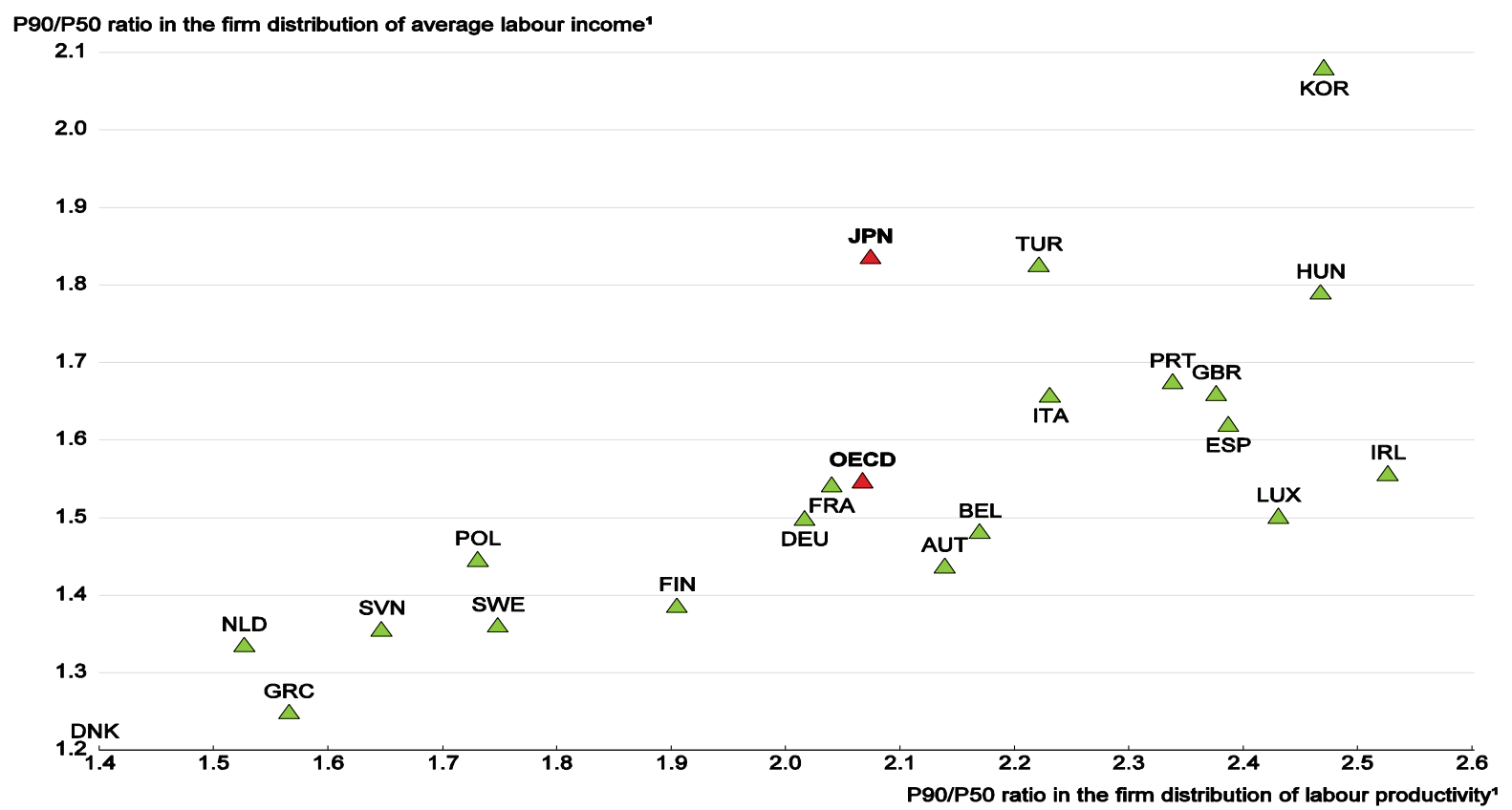

1. This figure compares the labour productivity and labour income at a firm at the $90^{\text {th }}$ percentile to one at the $50^{\text {th }}$ percentile. Source: OECD (2016i). 


\section{Improving exit and entry policies}

The 2013 Japan Revitalization Strategy set a target of raising firm exit and entry rates from 4-5\% to $10 \%$. The survival of non-viable firms reduces the efficiency of resource allocation by trapping capital and labour in low-productivity activities, thus widening the inter-firm dispersion of productivity and wages. It also discourages firm entry by inflating wage levels relative to productivity and depressing market prices. Consequently, potential entrants have to clear a higher productivity threshold to compensate for lower profitability and the congestion resulting from a large stock of non-viable firms discourages potential entrepreneurs. Moreover, the survival of non-viable firms slows the growth of more productive firms by making it more difficult to attract more resources and grow (Adalet McGowan et al., 2017). The market selection process is productivity-enhancing, as the productivity level of exiting firms is lower than that of surviving firms and new start-ups.

Declining MFP growth in Japan's manufacturing sector since the late 1980s has been mainly driven by falling productivity within existing firms, reflecting the limited prospects of old and small companies (Fukao and Kwon, 2011). Firm exit has made an increasingly negative contribution, as firms with aboveaverage productivity left the market, in part by moving overseas, while many non-viable firms remained. Firm entry contributed to productivity growth, though not enough to offset the falling contribution of productivity within firms. Finally, the contribution of resource reallocation was limited (Fukao, 2013).

\section{Improving exit policy to ensure the closure of non-viable firms}

The annual firm exit rate in Japan edged below $4 \%$ in 2012, which is low compared to other advanced countries (Figure 7). The low exit rate is due to several factors. First, following the financial crisis in Japan in the 1990s, forbearance lending - continued lending by financial institutions in cases where there is little hope that firms will ever repay the loans - emerged as a serious problem (Caballero et al., 2008). Second, the 2008 SME Financing Facilitation Act, which required financial institutions to review the terms of their loans to SMEs in response to requests by the borrowers (see below), encouraged such forbearance lending. Although the Act expired at the end of 2013, the authorities continue to encourage financial institutions to modify loan terms in response to requests from SMEs. The number of dissolutions, defined as a suspension of business that is not categorised as a bankruptcy, has risen during the past decade, driven by the retirement of small business owners with no one to succeed them (Panel B). The dissolution rate is three times higher than that of bankruptcies, the number of which has declined since the global financial crisis.

The low exit rate tends to boost the share of non-viable firms, defined as those with an interest coverage ratio below one for over three consecutive years. The share was relatively high in Japan in 2013 (Figure 8). Only $2 \%$ of firms identified as non-viable left the market during the following year, illustrating the weakness of the exit mechanism in Japan (Nakamura, 2017). The survival of non-viable firms reduces investment and employment in healthy firms. Their existence is estimated to have reduced investment and employment by a cumulative $2^{1 / 2}$ per cent and 3/4 per cent, respectively, in Japan over 2008-13, thereby preventing the expansion of healthy firms (Adalet McGowan et al., 2017). In more recent years, the aggregate interest coverage ratio has improved, which may have reduced the number of non-viable firms.

The existence of non-viable firms also contributes to the fact that, on average, Japanese firms show little growth (Figure 9). For example, the average size of mature firms (more than 10 years old) in the United States is relatively high at more than 70 employees in manufacturing and 40 in services, even though the size of new start-ups (less than two years old) is not especially large. In contrast, Japanese firms fail to grow, with average employment of only ten in manufacturing and six in services for mature firms (Criscuolo et al., 2014). In sum, structural change, whereby cohorts of new firms continuously displace obsolete firms, can raise productivity. 
Figure 7. Exit, bankruptcy and dissolution of firms in Japan

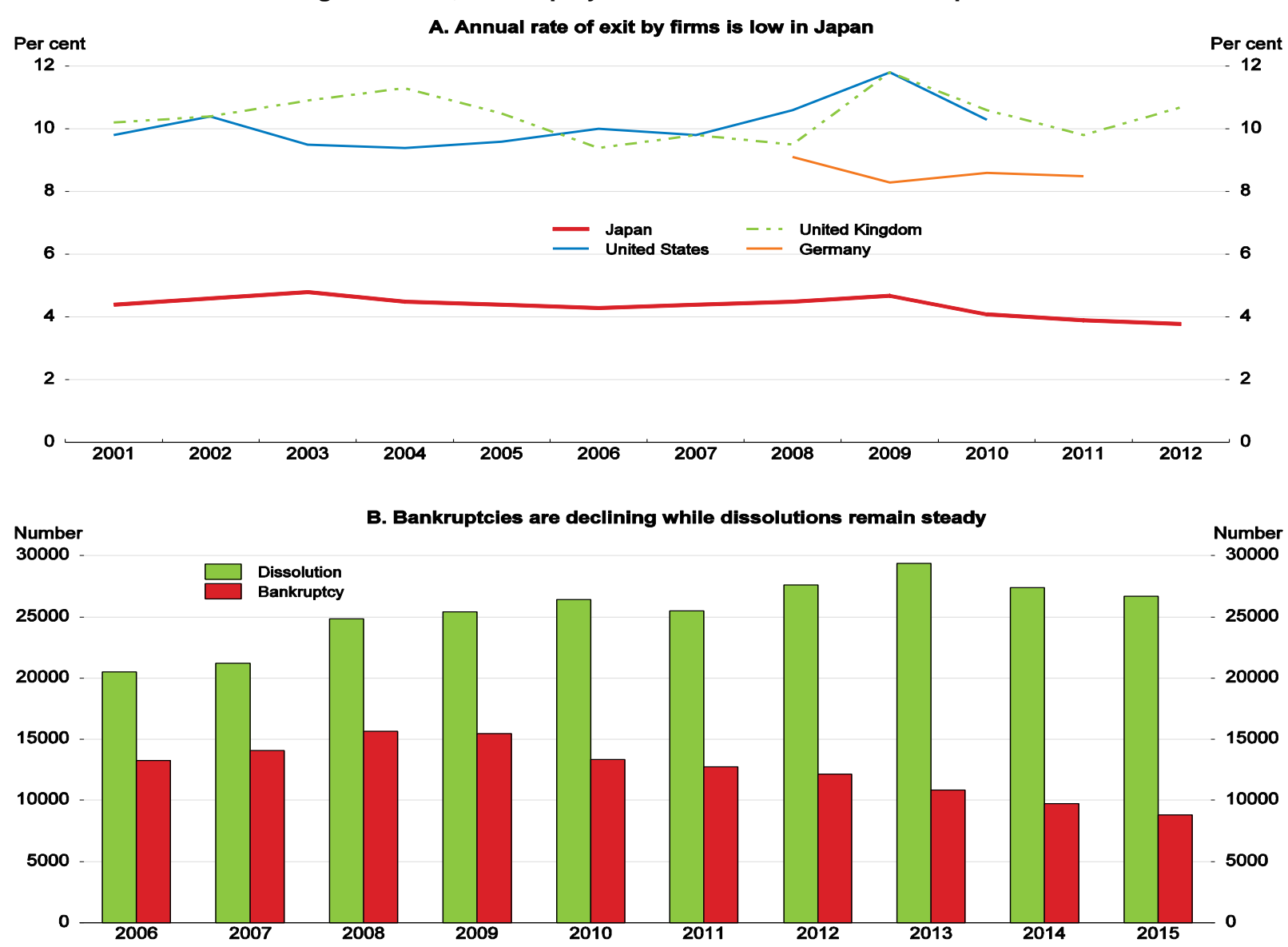

Source: Ministry of Economy, Trade and Industry (2014); Small and Medium Enterprise Agency (2016).

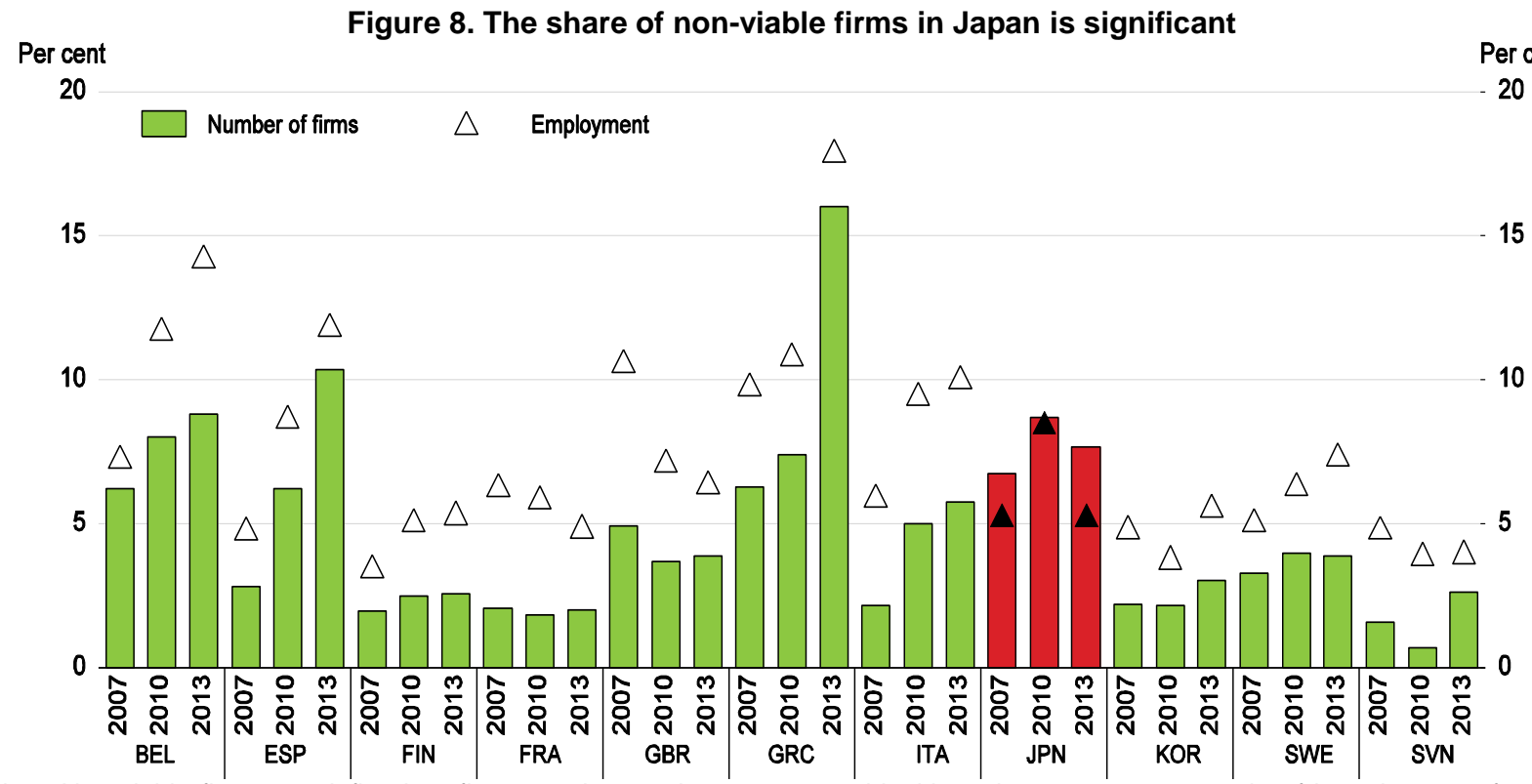

Note: Non-viable firms are defined as firms aged more than 10 years old with an interest coverage ratio of less than one for three consecutive years. Employment refers to the share of labour in non-viable firms.

Source: OECD Secretariat calculations using ORBIS database. 
Figure 9. Small firms in Japan tend to stay small

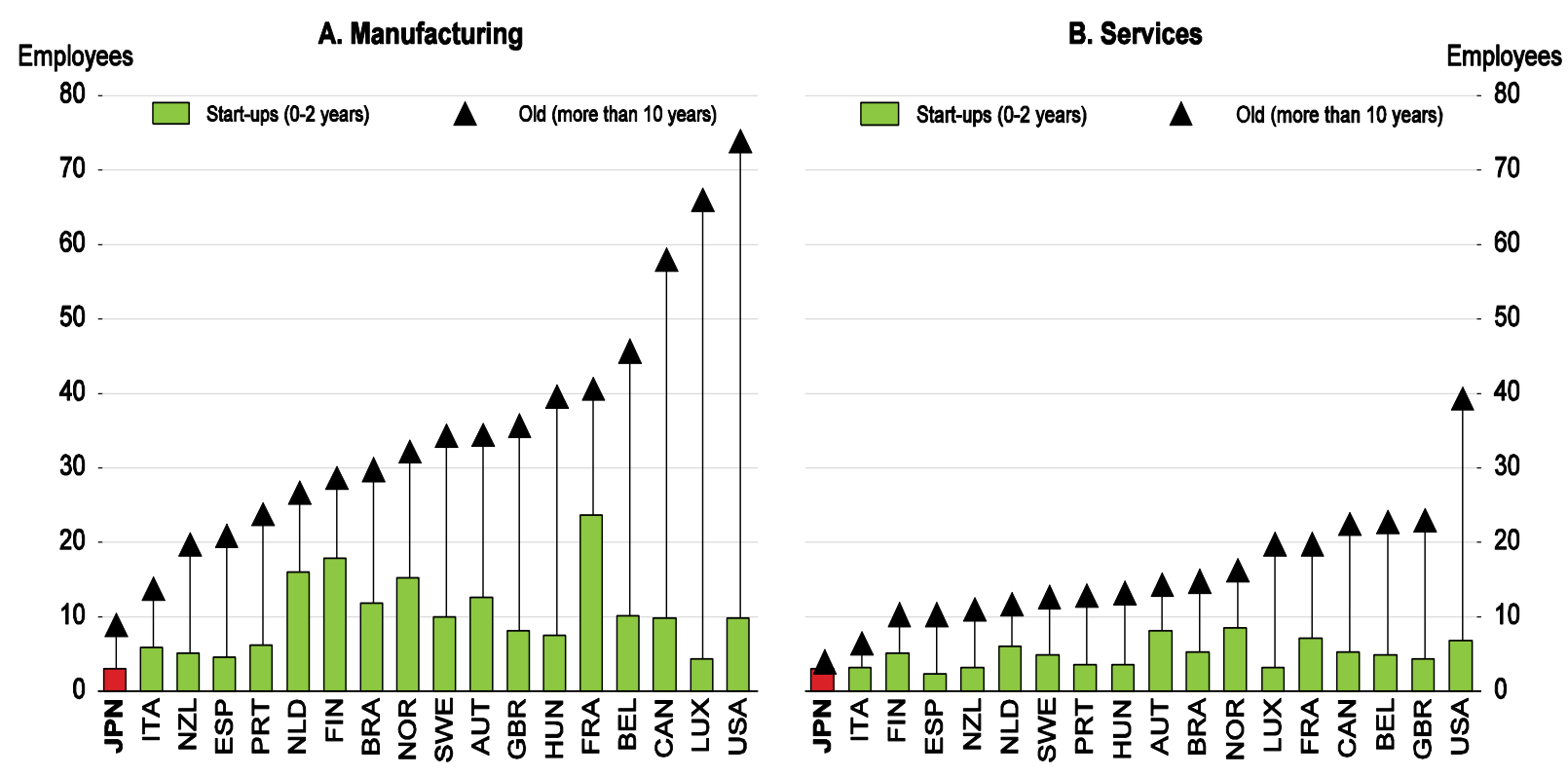

Source: Criscuolo et al. (2014).

\section{Reforming the insolvency regime}

While firm exit is affected by a number of policies, insolvency regimes are crucial to expedite the orderly exit of non-viable firms, despite several types of market imperfections: $i$ ) information asymmetries that lead debtors and creditors to value firms differently (Smith and Stroemberg, 2005); ii) incomplete contracts as it is difficult to write a complete contract ensuring an optimal outcome ex ante (Hart, 2000); and iii) co-ordination problems as the interest of individual creditors can conflict (Marinc and Vlahu, 2012). An efficient insolvency regime that overcomes these challenges strengthens market forces and facilitates the exit of non-viable firms, thereby improving the scope and speed at which resources sunk in failing firms are reallocated to more productive use (Adalet McGowan and Andrews, 2017). An efficient insolvency process also facilitates the restructuring of viable firms, thus promoting within-firm productivity growth. In sum, an effective insolvency regime reduces the dispersion of productivity and wages and promotes inclusive growth over the medium term.

The insolvency regime in Japan consists of a number of legal options and informal out-of-court procedures (Table 1). The main legal options are: $i$ ) liquidation through the Bankruptcy Law (hasan) and Special Liquidation (tokubetsu seisan), a fast-track approach; and ii) restructuring through the Civil Rehabilitation Law (minji saisei) and the Corporate Reorganization Law (kaisha kosei), which is rarely used. Of 8517 bankruptcies in 2015, liquidation accounted for 97\% (Teikoku Data Bank, 2016). Large firms account for most of the restructuring, as they seek to avoid the large negative effect of bankruptcy.

A number of mechanisms facilitate out-of-court procedures (Panel B). The Turnaround ADR (Alternative Dispute Resolution), which was created for the rehabilitation of companies suffering from financial difficulties, combines the advantages of the formal procedure (fairness) and out-of-court settlements (flexibility and speed). Out-of-court settlements may involve the Resolution and Collection Corporation (RCC), SME Revitalization Support Councils and the Regional Economy Vitalization Corporation of Japan (REVIC). These institutions differ in their objectives and mandates, but all primarily aim at restructuring, rather than liquidating, firms. 
Table 1. Legal insolvency procedures in Japan

A. Legal procedures

\begin{tabular}{llr}
\hline Objective & Procedure & Number in 2015 \\
\hline \multirow{2}{*}{ Liquidation } & & 7985 \\
& The Bankruptcy Law & 285 \\
Restructuring & Special liquidation proceedings & 246 \\
& The Civil Rehabilitation Law & 1 \\
Total & The Corporate Reorganization Law & 8517 \\
\hline
\end{tabular}

B. Out-of-court procedures

Resolution and Collection Corporation (RCC) (since 1999)

Resolving the non-performing loans of financial institutions through corporate revitalisation

The RCC was involved in preparing/establishing revitalisation plans in 695 cases as of March 2015 (cumulative total)

Regional Economy Vitalization Corporation of Japan (REVIC) (since 2013)

A broad range of activities to vitalise regional economies, including the revitalisation of firms

The REVIC has been involved in 47 cases as of March 2016 (cumulative total), mainly involving SMEs

SME Revitalization Support Councils (since 2003)

Specifically mandated to support revitalisation of SMEs by the Industrial Competitiveness Enhancement Act

The Councils have been involved in establishing revitalisation plans in 10518 cases (cumulative total) as of 2015

Turnaround ADR (since 2007)

Out-of-court settlement under the dispute resolution provider authorised by the Ministry of Economy, Trade and Industry

The ADR intervened in 45 cases as of March 2016 (cumulative total); around 35\% involved listed companies

Source: Teikoku Data Bank (2016).

Japan's corporate insolvency regime is highly efficient (Figure 10), in particular with regard to firm restructuring. The recovery rate - how much secured creditors recover from an insolvent firm at the end of insolvency proceedings - is among the highest in world at $92 \%$ versus the OECD average of $71 \%$ (World Bank, 2017). The high recovery rate reflects: i) the short average duration of insolvency proceedings, at 0.6 years versus the 1.8-year OECD average; and ii) the low average cost of insolvency proceedings at $4.2 \%$ of the debtor's assets versus the OECD average of $9.5 \%$. These favourable outcomes are a result of a number of positive practices in Japan:

- Insolvency proceedings start early, thus avoiding delays that reduce the possibility of successfully restructuring viable firms and lower the liquidation value of failing firms.

- After the restructuring proceedings, the debtor is allowed to obtain new credit, which is given priority only over ordinary unsecured creditors and not over secured creditors.

- The debtor is allowed to continue operations during restructuring proceedings, thus increasing the chance of a successful outcome, particularly as incumbent managers are allowed to stay in charge.

- Restructuring plans need only a requisite majority of creditors for approval, instead of requiring a unanimous vote, thus facilitating the timely restructuring of firms.

Japan's personal insolvency regime does not facilitate the exit of non-viable firms

Personal insolvency regimes are more important for entrepreneurs and small firms than corporate insolvency procedures (Armour and Cumming, 2008). The prevalence of personal guarantees and the stringency of the personal insolvency regime are the most important impediments to firm exit in Japan. 
Almost $60 \%$ of SMEs rely on personal guarantees by the owner and $10.5 \%$ of them have personal guarantees by someone outside the firm (Uesugi, 2010). The value of personal guarantees exceeds the owner's assets in 78\% of the cases (Mitsubishi UFJ Research and Consulting, 2010). Entrepreneurs receive only a small degree of liability protection (Berkowitz and White, 2004; Cumming, 2012). The owner of a failing firm who has given personal guarantees becomes liable if the assets of a failing firm cannot cover all of its liabilities. An owner who cannot pay the liabilities is forced into bankruptcy.

Figure 10. International comparison of corporate insolvency frameworks

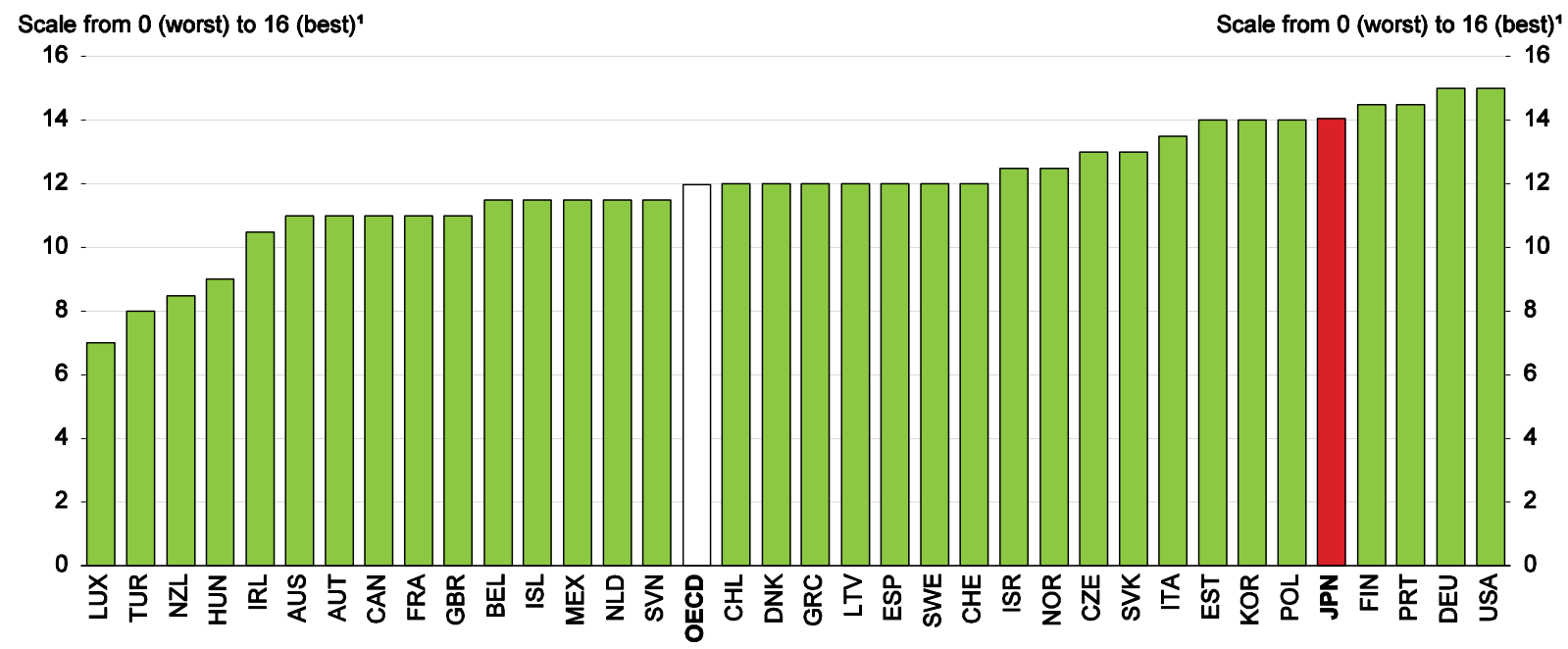

1. Based on recovery rate (cents on the dollar), time and cost (as a percentage of the estate). Source: World Bank (2017).

The incentives for exit are affected by the degree to which the owners' assets that are not directly linked to the bankrupt firm are exempted from bankruptcy proceedings. In Japan, exemptions of prebankruptcy assets from the bankrupt estate (i.e. the "legally protected assets") are limited to minimum personal items (Table 2). Pre-bankruptcy assets valued at more than 200000 yen (USD 1 760), including personal dwellings, are sold and the owner is left only with a maximum of 990000 yen (USD 8711 ), equivalent to a fifth of average annual earnings. In contrast, exemptions in the United States are much larger at up to USD 22975 for housing, USD 11525 for household goods and USD 3450 for motor vehicles. In the event of bankruptcy, 56\% of Japanese banks would claim all assets, excluding the legally protected assets, from the debtor (Yamada Business Consulting, 2011). Among owners, 59\% of owners answered they would be most anxious about life insecurity in the case of bankruptcy (Nomura Research Institute, 2014). Owners of non-viable firms thus have a strong incentive to prolong the life of their enterprise to avoid the negative ramifications of bankruptcy.

The restrictions imposed on the rights of bankrupt persons — so-called "disabilities" — also affect firm exit. Such restrictions are stringent in Japan (Table 2). In addition to losing the power to deal with the bankrupt estate, bankrupt persons face civic disabilities, such as exclusion from certain professions or professional groups. They may also be prohibited from traveling without the consent of the court and have their mail opened by the trustee. Strict restrictions on access to credit are also imposed on bankrupt persons. Their names are listed by the Credit Information Center and the Japan Credit Information Reference Center for up to ten years, thus denying them access to normal lending.

Japan grants more favourable treatment to bankrupt owners in exempting future earnings from the obligation to repay pre-bankruptcy debts - the so-called "availability of discharge". In Japan, it is available immediately after the court's decision, which is lenient by international standards. Although the 
availability of discharge is subject to certain conditions, it was granted in $97 \%$ of cases in 2012 . This eases the debtor's burden and thus facilitates smoother firm exit, while promoting firm entry.

Table 2. Personal insolvency regimes

Key features of personal insolvency regimes for businesses ${ }^{1}$

\begin{tabular}{lcccc}
\hline & $\begin{array}{c}\text { Discharge } \\
\text { availability }\end{array}$ & $\begin{array}{c}\text { Time to } \\
\text { discharge }\end{array}$ & Exemptions $^{4}$ & Disabilities $^{5}$ \\
\hline Austria & 0 & 7 & 2 & 0 \\
\hline Belgium & 0 & 0 & 1 & 3 \\
Canada & 0 & 0.75 & 0 & 2 \\
Denmark & 0 & 3 & 1 & 3 \\
Finland & 0 & 0 & 1 & 3 \\
\hline France & 0.5 & 0 & 2 & 2 \\
Germany & 0 & 6 & 0 & 1 \\
Greece & 1 & & 1 & 3 \\
Ireland & 0 & 12 & 1 & 2 \\
Italy & 1 & & 1 & 3 \\
Netherlands & 0 & 3 & 2 & 0 \\
Spain & 1 & & 1 & 3 \\
Sweden & 1 & 1 & 1 & 2 \\
United Kingdom & 0 & 0 & 1 & 2 \\
United States & 0 & $\mathbf{0}$ & 0 & 1 \\
\hline Japan & $\mathbf{0}$ & $\mathbf{1}$ & $\mathbf{3}$ \\
\hline
\end{tabular}

1. 2005 for all countries except Japan. For Japan, OECD estimates made in 2017.

2. Discharge availability $=0$ if discharge is available and 1 otherwise.

3. $\quad$ Time to discharge $=$ the number of years until typical discharge.

4. Exemptions relate to pre-bankruptcy assets that are exempted from the bankrupt estate. It takes the value: 1 if exemptions of assets from the bankruptcy estate cover only personal items, tools of trade, etc.; 0 if exemptions are more generous; and 2 if exemptions are negative (i.e., property of spouses can be pulled into the estate).

5. Disabilities relate to restrictions on the debtor's civil and economic rights related to bankruptcy: 0 if no disabilities other than the loss of power to deal with assets in the bankrupt estate; 1 for civic disabilities (i.e. loss of the right to vote, hold elected office, or membership in professional groups); 2 for economic disabilities (i.e., restrictions on obtaining credit or being involved in managing a company); and 3 for interference with mail and/or travel (i.e. prohibition on travel without consent and/or mail opened by trustee).

Source: Armour and Cumming (2008) for all countries excluding Japan. For Japan, preliminary estimates by the Secretariat.

\section{Policies to facilitate smooth exit of non-viable firms}

To ease the problems associated with bankruptcy, there have been discussions in Japan about expanding exemptions, including for personal dwellings, from the bankrupt estate. The benefits of higher exemptions should be weighed against the risk of credit rationing. Higher exemptions might induce startups by entrepreneurs with low-quality projects, which could lead to a tightening of credit supply. In the United States, states with lenient exemptions were associated with greater incidence of credit rationing by lenders to small businesses (Berkowitz and White, 2004), as there was a higher probability of default (Persad, 2004).

The orderly exit of non-viable firms could be facilitated by greater co-operation among the parties concerned. In 2014, the Guidelines for Personal Guarantees Provided by Business Owners were introduced to provide a common set of voluntary standards for self-regulation by SME groups and financial institution associations regarding guarantees by SME owners. The Guidelines expedite out-of-court settlements for 
debt resolution within a framework of institutionalised procedures, such as intervention by REVIC or SME Revitalization Support Councils (Table 1). According to the Guidelines:

- The financial state of the firm should be made transparent, allowing the parties concerned to correctly evaluate the true value of the firm, which often reveals hidden assets of the debtor.

- Launching debt resolution at early stages prevents the deterioration of the firm's financial status and the obsolescence of its assets, and raises the amount of assets collected by the creditor.

- As the amount of collectable assets is increased, it can be shared with the debtor, allowing him or her to retain more assets, including private dwellings, than in the case of personal bankruptcy.

- As the debtor avoids personal bankruptcy, no information is transmitted to the credit registers, allowing him or her to retain access to lending.

The Guidelines state that banks should not require personal guarantees by SME owners in contracting new loans when SMEs fulfil certain conditions. This will improve lending practices and remove obstacles that limit early exit, restructuring, and second chances by SME owners. Since the implementation of the Guidelines in 2014, government financial institutions have raised the share of loans without personal guarantees from $15 \%$ to $33 \%$ by September 2016, while private banks increased the proportion of such loans from $12 \%$ in 2015 to $14 \%$ in 2016. The share of loans without personal guarantees should be increased further.

As for existing personal guarantees, the Guidelines bring debtors and creditors together in an out-ofcourt setting. However, the Guidelines were used to dissolve personal guarantees in only 207 cases by private financial institutions and 61 cases by government financial institutions in FY 2015, and thus should be used more widely. As stated in the 2016 Japan Revitalization Strategy, both government and private financial institutions should be encouraged to make greater use of the Guidelines. The government should also diffuse information on best practices so that banks can understand the merits of using the Guidelines (see above), and set up related legislation which facilitates out-of-court settlement.

The Guidelines address a number of market imperfections, but the implementation should be improved. First, the creditor needs to play a larger role in initiating the procedure at an early stage, as the owner/debtor is reluctant in most cases to resolve the firm. This would be facilitated by establishing an early warning system that can help identify distressed companies at an early stage. Second, the coordination of the interests of different creditors should be facilitated. In this respect, the Japan Federation of Bar Associations' proposal that lawyers, tax accountants, certified public accountants, and small business consultants intermediate within the framework of the Special Conciliation Proceedings could help.

While there are many economic benefits from facilitating the exit of non-viable firms, it would initially boost the number of displaced workers. In 2014, 8.0 million people found a job (17.3\% of the total number of workers) and 7.1 million left a job (MHLW, 2015). Less than half of displaced workers in 2014 were re-employed within one year, while a quarter left the labour force, at least temporarily. Reemployment probabilities are higher for men than for women, increase with education and decrease with age and job tenure (OECD, 2015a). The increasing labour shortage in Japan does increase re-employment opportunities for those leaving jobs. Still, policies are needed to facilitate the re-employment of workers, including those who were employed at firms that exited. OECD evidence shows that active labour market policies are more effective in helping displaced workers following firm exit, compared with other categories of job seekers (Andrews and Saia, 2016). In addition, policies to encourage firm creation will help create new opportunities for displaced workers. 


\section{Encouraging firm entry and entrepreneurship}

Japan's annual firm entry rate, at between $4 \%$ and $5 \%$, is well below other advanced economies (Figure 11). Consequently, firms more than ten years old account for three-quarters of Japan's small enterprises (less than 50 workers) compared to less than half in most OECD countries (Panel B). Firm creation is essential to boost productivity given the key role of start-ups in innovation (OECD, 2015e). New firms boost aggregate productivity by displacing less-productive firms, placing incumbents under competitive pressure and enabling the commercialisation of knowledge that would otherwise remain unused. The correlation between start-up rates and productivity growth is positive, although the impact on recorded labour productivity growth may not be immediate (OECD, 2016b). The entry of dynamic startups that displace low-productivity firms also promotes inclusive growth by reducing inter-firm wage dispersion. In addition to increasing the exit rate, encouraging entrepreneurship would help achieve the Revitalization Strategy goal of boosting the firm entry rate to $10 \%$.

Figure 11. Japan's annual firm entry rate is lower than in other advanced economies
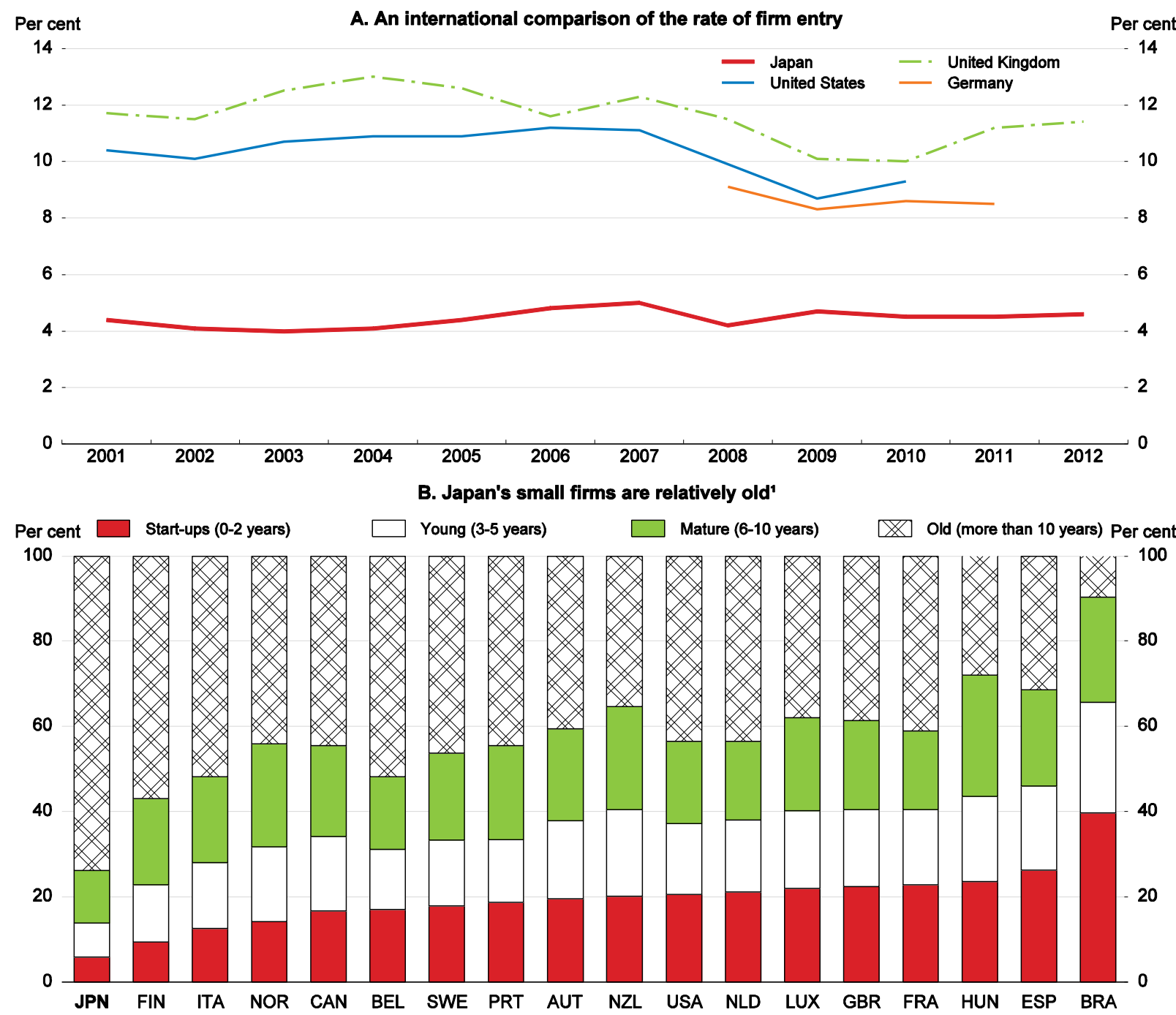

1. Firms with less than 50 workers. From 2001 to the latest year available (2009 in the case of Japan).

Source: Ministry of Economy, Trade and Industry (2014); Criscuolo et al. (2014). 


\section{Interest in entrepreneurship is relatively weak in Japan}

The number of entrepreneurs in Japan (as a share of those employed) is among the lowest in the OECD area at $3.1 \%$ of men and $0.9 \%$ of women (Figure 12). Although regulatory barriers to entrepreneurship have fallen below the OECD average, the complexity of regulatory procedures remains a major obstacle to entrepreneurial activity, largely related to the licence and permit system (OECD, 2013c). Increasing entrepreneurship also requires improving its image; less than a third of the working-age population views entrepreneurship as a good career choice, the lowest among OECD countries (Figure 13). The negative perception reflects a lack of perceived opportunities (7\%, the lowest in the OECD), perceived capabilities (12\%, the lowest in the OECD) and a fear of failure (55\%, the second highest in the OECD) (Panel B). Consequently, employees with attractive business ideas and technologies tend to remain in large enterprises. In a 2013 survey on the reasons for Japan's low business entry rate, 30\% of respondents cited "social norms that encourage employment at large enterprises and other forms of stable employment" (Mitsubishi UFJ Research \& Consulting, 2013). Only 2.5\% of the working-age population intends to start a business within three years, the lowest share in the OECD (Panel B).

Figure 12. The share of entrepreneurs in Japan is low, especially among women

Self-employed with employees (as a share of employed persons) in 2015

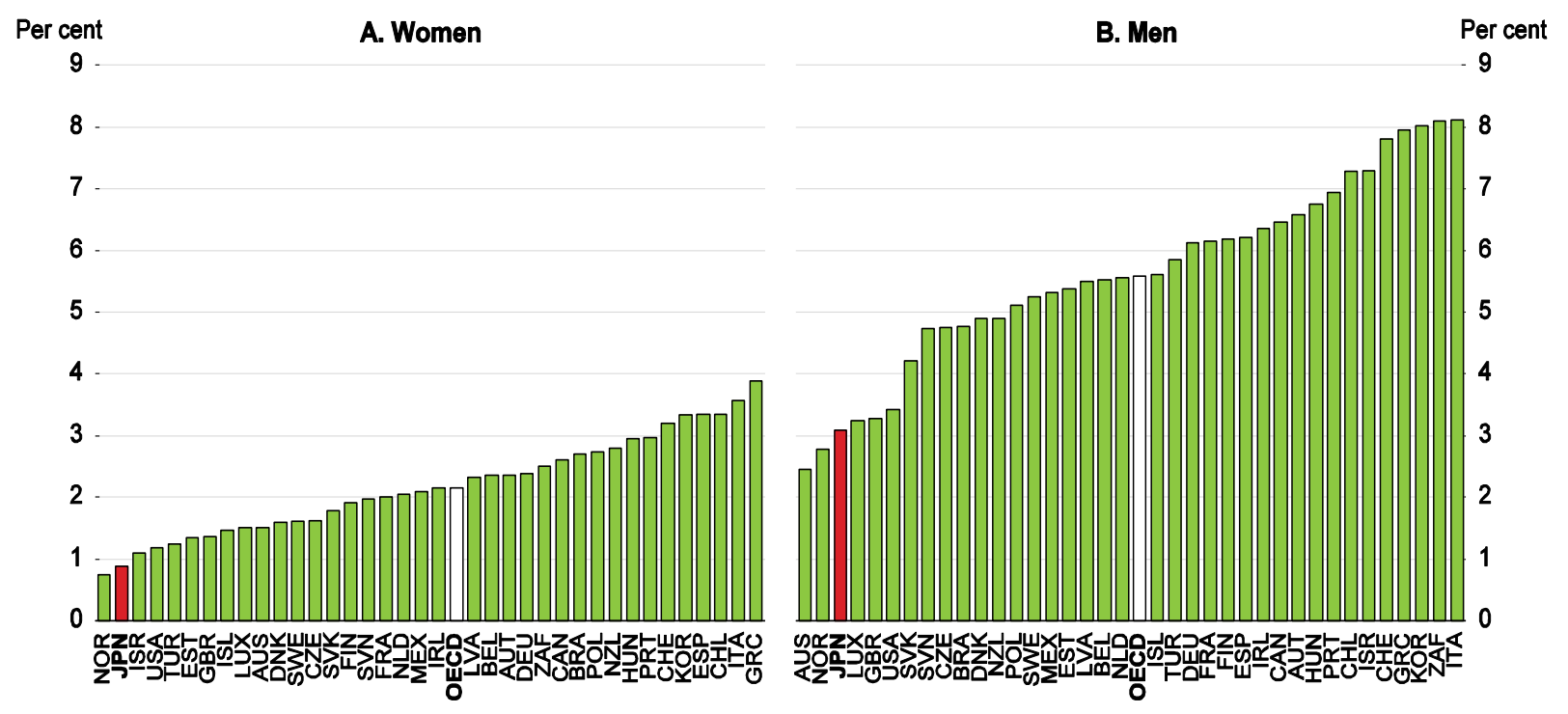

Source: OECD (2016b).

The low perceived capabilities in entrepreneurship reflect a lack of education and training. Only $20 \%$ of the Japanese, the lowest share in the OECD, agree that "school education had provided enabling skills and know-how necessary to run a business", compared to an OECD average of 52\% (OECD, 2013a). Training is also a priority, as only $31 \%$ of men and $18 \%$ of women said that they had access to entrepreneurial training, compared to OECD averages of $51 \%$ and $44 \%$, respectively (Figure 14).

\section{Policies to promote entrepreneurship}

It is essential to simplify licence and permit systems and to relax product market regulation, particularly in promising areas, such as healthcare and energy. In addition, it is important to improve the public image of entrepreneurship and increase know-how through educational programmes. Japan has established the SME Training Institute, which offers seminars for owners and managers of SMEs. One aspect is financial education, which can help SMEs use market-based financing instruments other than bank lending (OECD, 2015f). The government has launched educational programmes such as the 
Enhancing Development of Global Entrepreneur Program. However, these programmes are mainly aimed at university and graduate students. Country experiences in this area suggest that (OECD, 2016d):

- Entrepreneurial skills need to be fostered in primary and secondary schools. Ireland, for example, has programmes for children from age ten.

- Entrepreneurship education should be broad in nature and go beyond career education. A recent EU study on entrepreneurship education focuses on creativity, entrepreneurial know-how, responsibility, risk-taking, problem solving, and teamwork (European Commission, 2013).

- Achieving high-quality entrepreneurial education requires inter-ministerial cooperation, as well as the support of public institutions and the private sector.

Figure 13. Views on entrepreneurship in Japan are negative
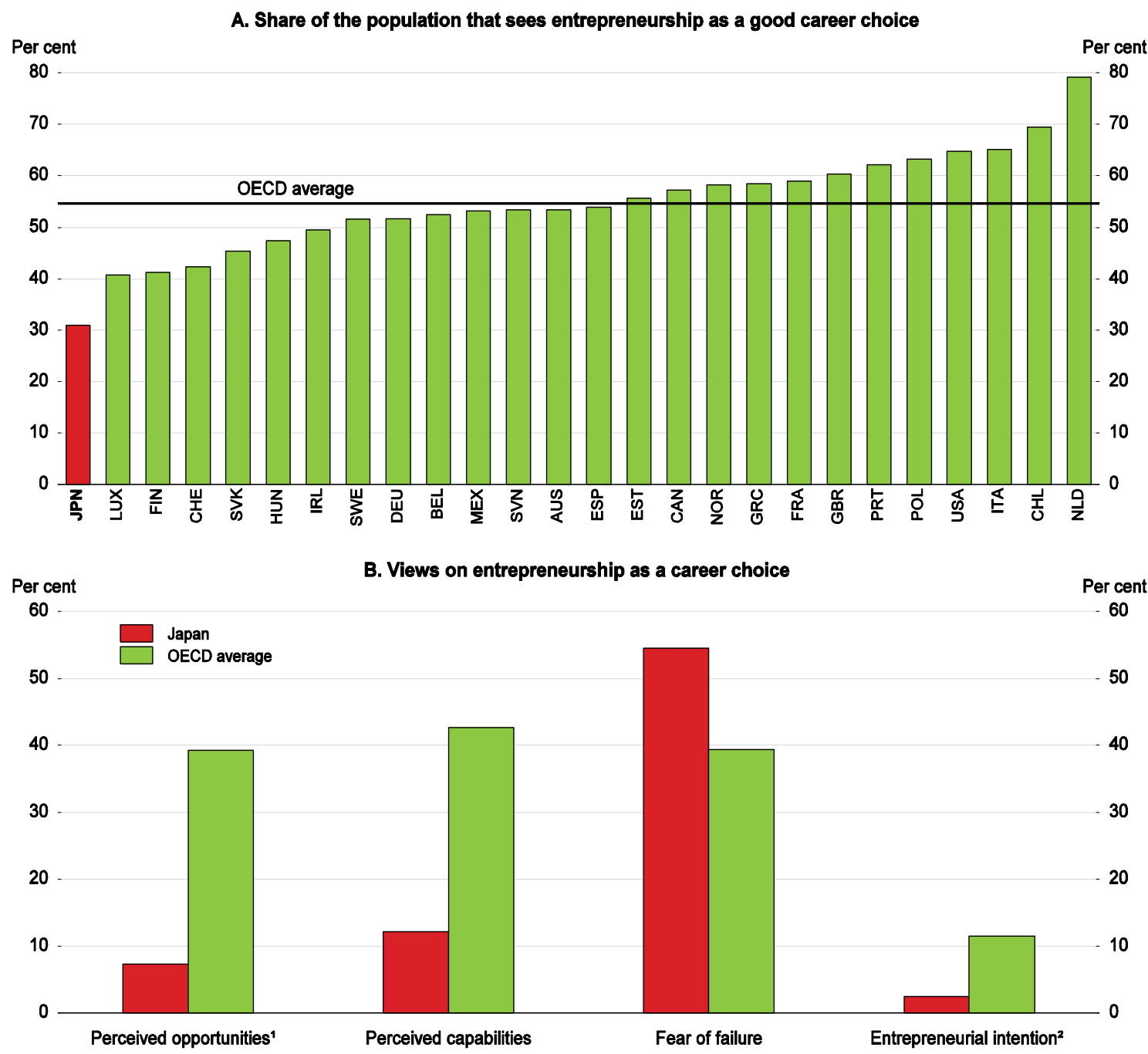

1. Share of adults who perceive good opportunities to start a business.

2. Share of adults who are not involved in entrepreneurial activity and expect to start a business within three years.

Source: Global Entrepreneurship Monitor (2015).

It is also necessary to address the issue of financing for potential entrepreneurs. The share of Japanese men who report that they have access to financing matches the OECD average, while it is below average for women (Figure 14, Panel B). The range of financing instruments available to entrepreneurs, particularly risk capital, should be broadened. Access to venture capital is a key driver of the diffusion of best practices (Andrews et al., 2016). The availability of venture capital investment plummeted from its 2007 peak in the 
aftermath of the financial crisis and has experienced an uneven recovery since then (OECD, 2016c). In 2015 , venture capital amounted to only $0.02 \%$ of GDP, compared with more than $0.3 \%$ in Israel and the United States (Figure 15).

Figure 14. Access to entrepreneurial training and finance is relatively low in Japan, especially for women Percentage of persons in 2013 who say that they had access to:
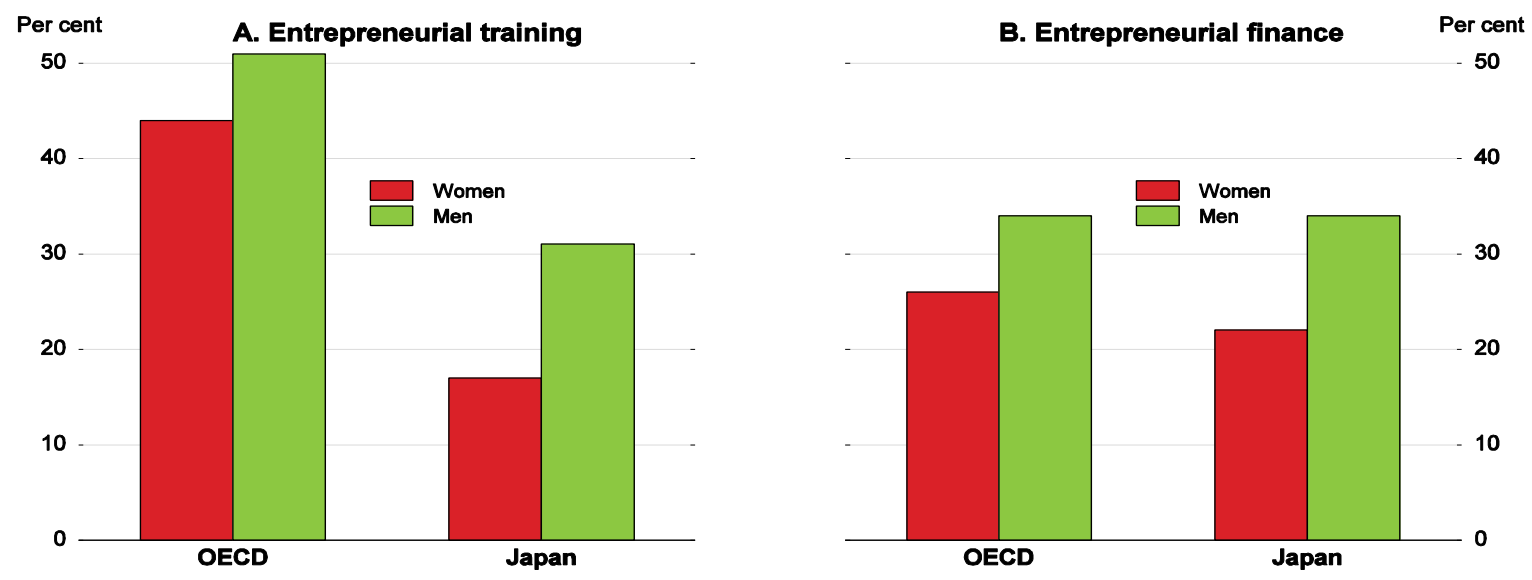

Source: OECD (2016b).

In addition, venture capital is focused on more mature firms rather than start-ups, reflecting problems in the merger and acquisition (M\&A) market and initial public offerings (IPOs), two methods that allow investors to recover their investments (Jones and Kim, 2015). M\&A activity is relatively limited (EBC, 2014) and IPOs typically take seven to ten years due to regulatory hurdles. After peaking at 153 in 2004, the number of IPOs in Japan fell to only 23 in 2009, but rebounded to 84 in 2016. The trend was similar in the JASDAQ market for small equities, with 58 IPOs in 2006 versus only 15 in 2009 . Venture capital funds typically operate for only five years and then must return invested capital to investors. Given their limited time horizon, most venture capital funds avoid investing early in a firm's life and instead wait until three or four years before an IPO, thus limiting financing for start-ups (Solomon, 2016). Developing the M\&A market and shortening the time for IPOs would boost opportunities for entrepreneurs. Given the strong interdependence between various types of SME financing, healthy and vibrant IPO markets are important for the functioning of the entire funding spectrum of SMEs (Nassr and Wehinger, 2016).

Figure 15. The venture capital sector is relatively undeveloped in Japan In 2015

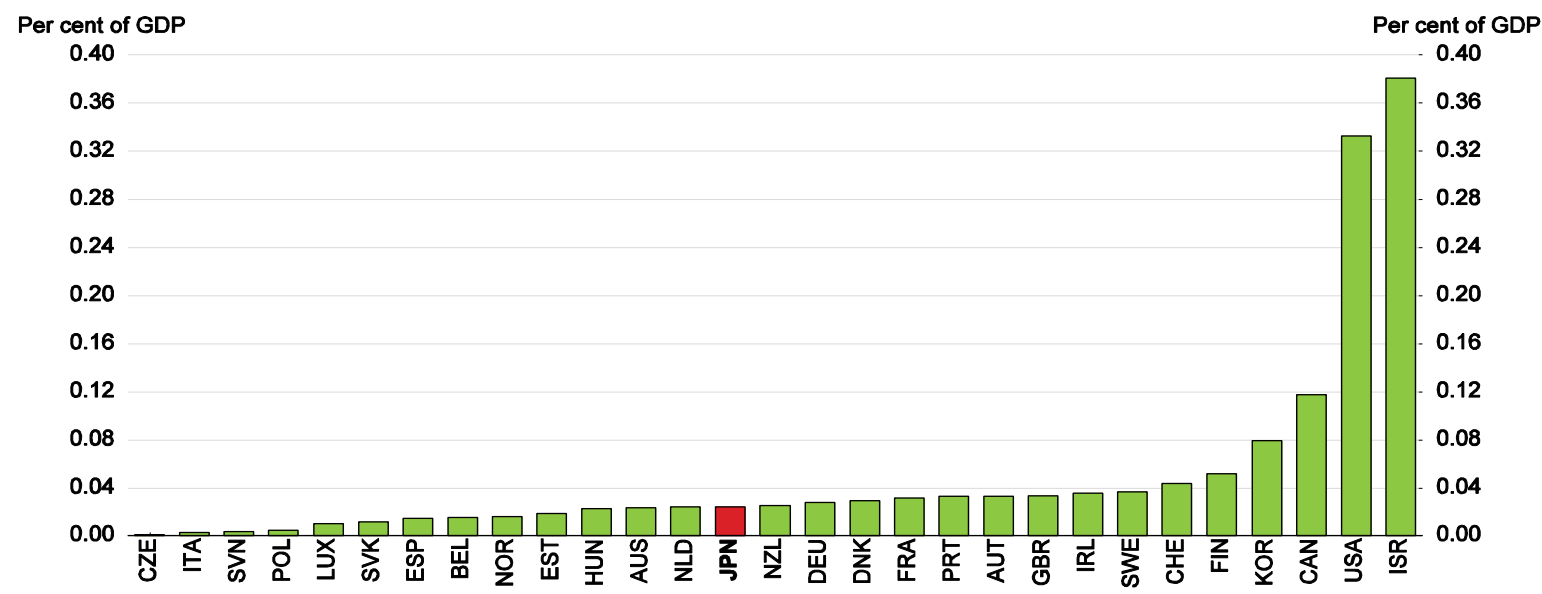

Source: OECD (2016b).

Expanding the scale of venture capital requires improving the environment for angel investors. Business angels should play a more prominent role in Japan, as they do in many countries. In addition to 
supplying financing, they also provide mentoring and networks. This is particularly important in Japan, given that so few people believe that they have the skills needed to start a new business. The tax system for business angels is being made more user-friendly by streamlining application procedures. In addition, venture capital funds should be expanded. One important potential source is pension funds, which do not currently invest in venture capital. While pension funds have to be cautious in investing in risky assets, some investment in venture capital "fund of funds" would help boost their returns.

The corporate sector plays a major role in venture capital in Japan, accounting for around threequarters of the total compared to a quarter in the United States. For corporations, venture capital investment is similar to R\&D spending. Given their large cash holdings (see below), the corporate sector's role could be much larger, but is limited by their tendency to do innovation in-house. In recent years, there has been a worldwide trend toward "open innovation in global networks", in which firms collaborate with external partners, such as suppliers, customers and other companies, both at home and abroad (2015 OECD Economic Survey of Japan). Open innovation thus provides a much broader base of ideas and technologies. However, Japanese firms have not embraced open innovation to the same extent as their foreign peers, reflecting concerns about losing technology to competitors (Motohashi, 2013). Promoting open innovation in Japan could help increase business investment in venture businesses and the creation of new start-ups.

In addition, the stigma attached to failure should be reduced so that potential entrepreneurs are not scared away by the lack of second chances. The share of Japanese who agree that entrepreneurs who fail should have a second chance was the second lowest in the OECD in 2012 (OECD, 2013a). Reducing the role of personal guarantees and the stringency of the personal bankruptcy system, as discussed above, would help create an environment that allows second chances. Moreover, there should be channels through which the experience and knowledge of failed entrepreneurs can be used to benefit others.

Encouraging entrepreneurship among women would also boost the firm entry rate, while promoting inclusive growth by more fully using the talents of women. The rate of entrepreneurship among women in Japan is the second lowest in the OECD (Figure 12), reflecting cultural attitudes and perceived barriers. Only $14 \%$ of Japanese women believe self-employment is feasible, compared to $40 \%$ in the United States and $34 \%$ in Korea (OECD, 2016d). While the measures undertaken to increase female employment and gender diversity in firms may also boost female entrepreneurship, a comprehensive action plan is needed. It should promote access to financing, awareness campaigns and networks for female entrepreneurs. Expanded training support is also needed as the share of women who say they have access to training is the third lowest in the OECD (Figure 14).

\section{Other policies to promote synergy between higher productivity and inclusive growth}

This section discusses other policies to narrow the productivity and wage gap between leading and lagging firms, including liberalising product market regulations, upgrading the corporate governance framework, enhancing R\&D collaboration between sectors and increasing international openness.

\section{Product market reform to promote entrepreneurship and innovation}

The stringency of product market regulation (PMR) has a significant relationship with aggregate productivity across the OECD (Bouis et al., 2011). The gap between frontier firms and laggards is greatest in industries in which regulation restricts competition. Available estimates suggest that up to half of MFP divergence could have been avoided and the diffusion of best technologies could be accelerated if countries engaged in more extensive market liberalisation, in particular in services (Andrews et al., 2016).

Reforms that lighten burdens on firms and increase the transparency of regulatory regimes support entrepreneurship and market entry. Less restrictive regulations can also narrow the gap between leading 
and lagging firms by allowing innovative new firms to attract the resources necessary to implement and commercialise new ideas. In a firm that experienced a $10 \%$ increase in patents over 2002-10, it is estimated that its workforce rose by $2.4 \%$ in the country with the least stringent PMR but by only $0.7 \%$ in the country where it is most stringent (Andrews et al., 2014). In turn, greater allocative efficiency results in faster productivity gains. Moreover, a decrease in PMR is found to have a positive impact on patenting activity. A hypothetical reduction in Finland's PMR in 2008 to the OECD average is estimated to result in a 3\% rise in patents per capita. In contrast, higher PMR stifles innovation and growth; convergence to the technological frontier is slower for countries with higher PMR, thus maintaining the dispersion of productivity and wages (Westmore, 2013).

Japan's PMR index in 2013 was slightly below the OECD average, but well above that of the leading countries (Figure 16). Priorities for regulatory reform in Japan include: $i$ ) reducing regulatory protection of incumbents, which is well above the OECD average; ii) reducing administrative burdens on start-ups, where Japan is below the OECD average but above the best-performing countries; and iii) reducing the complexity of regulatory procedures, where Japan matches the OECD average.

Figure 16. There is scope to align Japan's product market regulation with OECD best practice In $2013^{1}$

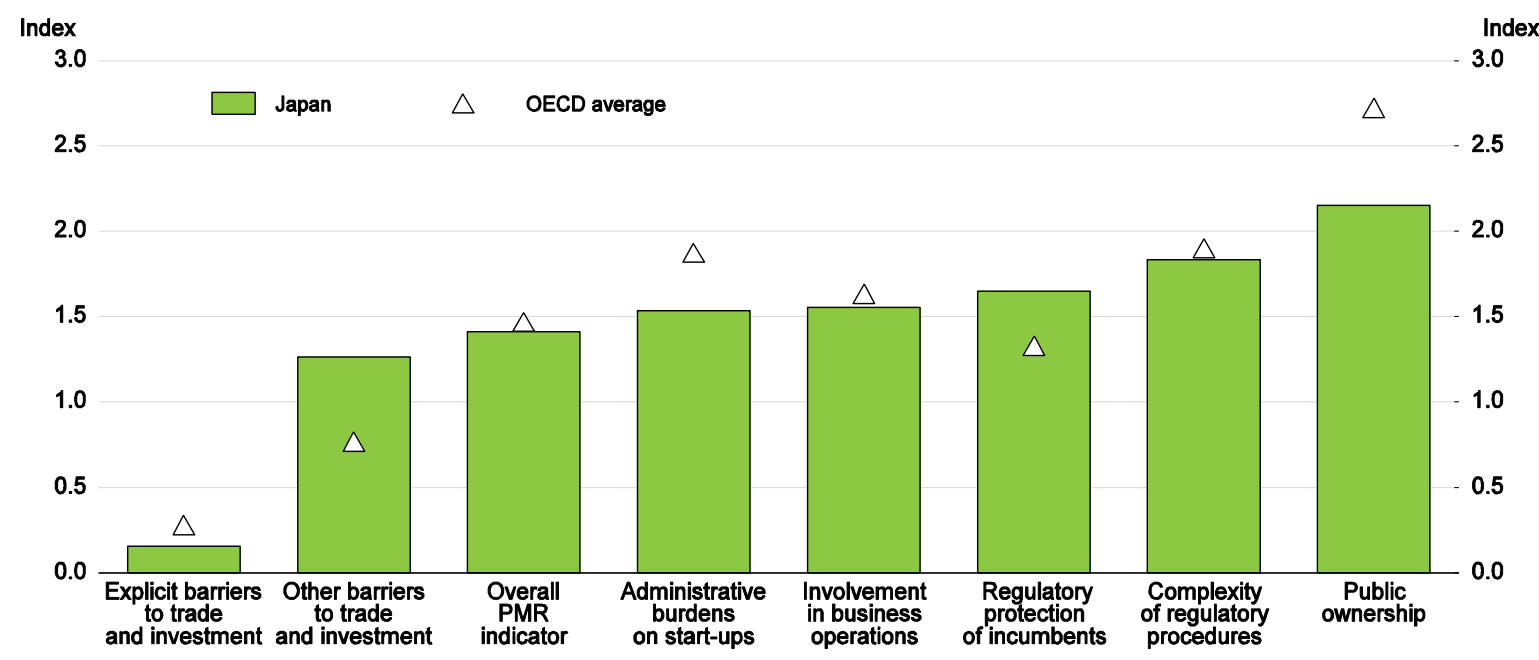

1. The OECD Indicators of Product Market Regulation are a comprehensive and internationally-comparable set of indicators that measure the degree to which policies promote or inhibit competition. Research shows that the indicators have a robust link to performance. The indicator, based on more than 700 questions, ranges from zero (most relaxed) to six (most stringent).

Source: OECD (2017f), OECD Product Market Regulation Statistics (database); Koske et al. (2015).

The government's Growth Strategy 2016 lists three priorities - National Strategic Special Zones (2015 OECD Economic Survey of Japan), corporate governance (see below) and labour market reform (see below). Regulatory reform is the task of two councils:

- The Council for the Promotion of Regulatory Reform, with a mandate from 2016 to 2019, consists of 14 members from the business sector, academia and research institutes. It presents annual reports on regulatory reform.

- The Council on Economic and Fiscal Policy (CEFP), established within the Cabinet Office in 2001, advises the Prime Minister on economic policy, including regulatory reform. It consists of four private-sector experts, five ministers and the governor of the Bank of Japan.

Regulatory reform should focus on service industries, where productivity has lagged. In some services, regulations limit or prohibit the entry of corporations on the grounds of protecting consumers, 
thereby ensuring a large role for non-profit organisations (including social welfare corporations). The rationale is that corporations exploit consumers to maximise their profits, whereas non-profit organisations do not. Based on this logic, corporations are not permitted to manage hospitals and the purchase of farmland is limited to agricultural production corporations that satisfy certain requirements. Even when corporations are allowed to provide social services, they are not granted the same tax advantages or government subsidies available to non-profit organisations providing similar services. Such exclusion of corporations provides de facto protection for small non-profit organisations (Yashiro, 2016). Such regulations on the entry of corporations prevent scale economies and the widening of consumer choice. Many of the fastest-growing sectors in the Japanese economy - such as health and long-term care and childcare - are thus largely off-limits to corporations, limiting productivity gains.

\section{Improving corporate governance}

Japanese firms have long been characterised by low return on equity (ROE) compared to their European and US counterparts (2015 OECD Economic Survey of Japan). Better corporate governance would improve their access to equity, the allocation of capital and the monitoring of firm performance (Isaksson and Çelik, 2013). In turn, this would allow Japan to make better use of its high level of business R\&D and human capital to raise productivity. Improved corporate governance could also encourage the corporate sector, which has exceptionally high cash holdings, to find ways to productively use their cash for capital investment. Following Japan's banking crisis, an increasing number of companies achieved zero-leverage in effective terms, with cash holdings exceeding outstanding debt. Such firms accounted for around $40 \%$ of the total in 2010 (Nakamura, 2017). Firms put a priority on reducing debt and amassing cash rather than maximising their enterprise value, and became more cautious about indebtedness.

Corporate governance also affects income inequality by influencing the pace of employment adjustment and the exit of non-viable firms. Japan's traditional corporate governance system, which tends to favour stakeholders over shareholders, featured life-time employment and limited labour mobility (Odaki and Kodama, 2014). Moreover, the dominance of large shareholders and high cross-shareholding slowed down the speed of employment adjustment. In addition, firms with corporate boards dominated by insiders are more likely to protect employees, while those with outside directors tend to pursue employment adjustment (Abe and Shimizutani, 2007). An improved corporate governance framework would facilitate the downsizing or closing of low-productivity activities and the shift of resources to high productivity activities, helping reduce the variance in wages in the medium term.

The government has placed unprecedented focus on corporate governance during the past few years, despite opposition from some business groups. One of the ten key reforms in the Revitalization Strategy is to "enhance corporate governance, aiming at sustainable growth in corporate value". To achieve this objective, Japan introduced a Stewardship Code for institutional investors in 2014 and a Corporate Governance Code for publicly-listed companies in 2015.

\section{The Stewardship Code}

The Stewardship Code requires participating institutional investors to engage in "constructive dialogue" with the firms in which they invest in order to "support the sustainable growth of companies". Institutional investors play an increasingly important role in corporate governance in many countries (OECD, 2011). However, institutional investors in Japan, whether they be asset managers or the asset owners themselves, have long been criticised for being too cosy with corporations and taking a passive approach, such as blindly voting in line with management or failing to vote (Hogan, 2015). Some companies arbitrarily forbid the participation and voting of institutional investors at shareholder meetings (Smith and Chern-Yeh, 2016). 
The Stewardship Code includes seven principles that apply to institutional investors on a "comply-orexplain" basis (Figure 17). The first principle requires institutional investors to publicly announce their policies to fulfil their stewardship responsibilities. Some commitments are quite specific, such as demanding a minimum 5\% return on equity, a rate not achieved by around a third of listed companies. Institutional investors are also expected to have an "in-depth knowledge" of the firms in which they invest (principle 7), so that they may constructively engage with firms, as stated in the Code. Perhaps most importantly, the sixth principle requires institutional investors to regularly report to beneficiaries concerning their actions to fulfil their stewardship. In addition to boosting the return to their clients, institutional investors that fulfil these functions perform a socially beneficial role by providing new information that will improve resource allocation (Çelik and Isaksson, 2013).

By December 2016, more than 200 institutional investors had joined the Code, with foreign investors accounting for nearly half. Market pressures are likely to continue increasing the number, as institutional investors who fail to adhere to the Code will lose clients. Investment managers account for more than twothirds of participating institutions, with insurance companies and trust banks accounting for most of the remainder. The rate of compliance with the seven principles ranges from $94 \%$ to $97 \%$ (Figure 17). According to a survey by the Government Pension Investment Fund, 61\% of the companies in the JPX Nikkei Index 400 appreciated the change in institutional investors' behaviour following the Code's introduction. In particular, they found discussions about long-term business strategy to be useful. However, companies expressed concern that institutional investors focus too much on the short term and lack an understanding of their business (GPIF, 2016).

\section{Figure 17. Share of institutional investors complying with the Stewardship Code's principles}

As a percentage of institutional investors that have accepted the Code

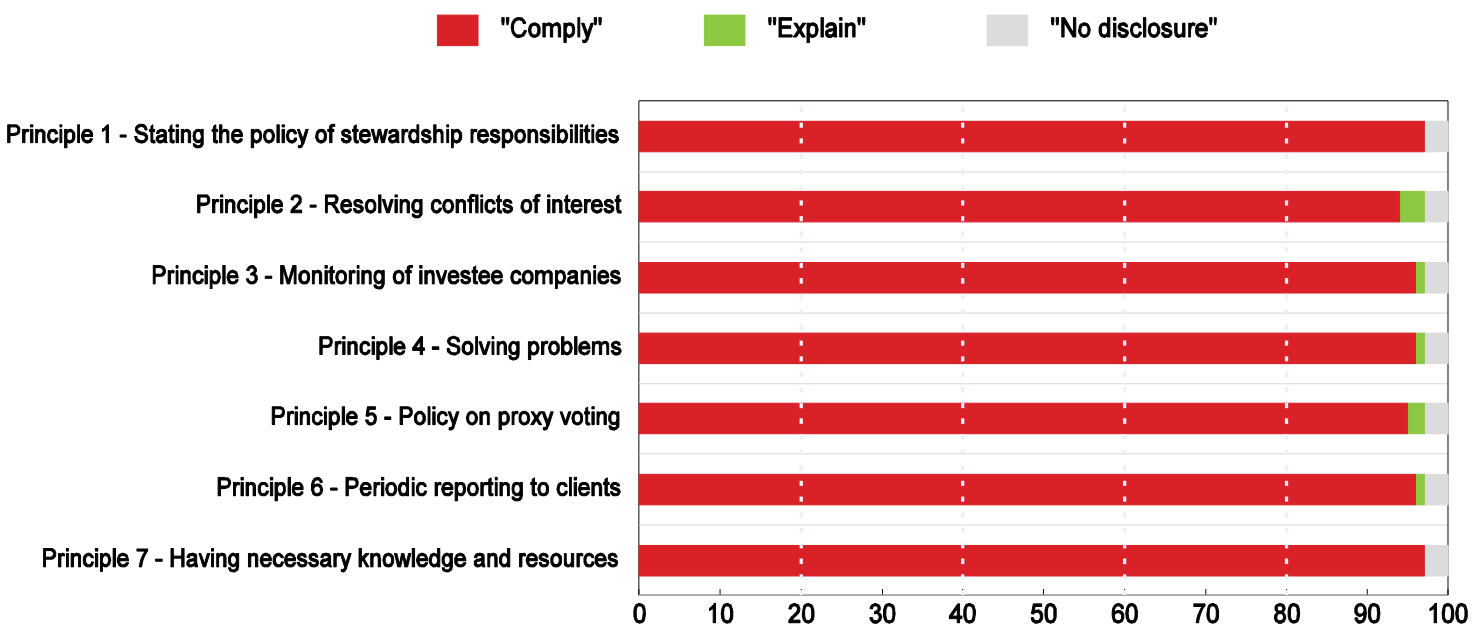

Source: Financial Services Agency (2017).

Further encouraging the end asset owners to join, if appropriate, would make the Stewardship Code more successful. Corporate pension funds are sizable customers of the fund managers that have joined the Code, and could influence the policies of the fund managers. The Government Pension Investment Fund, which is by far the largest asset owner, has joined the Code and outsourced its asset management activities to fund managers who have also adopted it. While other public pension funds and the Pension Fund Association have joined the Code, only one non-financial corporate pension fund has joined it thus far. Some argue that corporate pension funds are afraid of conflict with the firms they invest in and with which their parent company has business ties. Measures by the Financial Services Agency to address these issues would make the Code more effective. 


\section{The Corporate Governance Code}

In 2015, Japan became one of the last OECD countries to introduce a corporate governance code. Japan's Code is based on the OECD Corporate Governance Principles and is applied on a comply-orexplain basis. By December 2016, 84.7\% of the 2530 firms in the first and second sections of the Tokyo Stock Exchange (TSE) complied with at least $90 \%$ of the 73 principles in the Code and $19.9 \%$ complied with all of them (TSE, 2016). The Code has also prompted important changes in the governance framework. For example, the number of companies with advisory committees on nomination and remuneration, which are optional, more than doubled between July 2015 and May 2016.

The revision of the Companies Act in 2015 mandated one outside director and the Code mandated two independent directors, both on a comply-or-explain basis (the definition of independent director is stricter than that of an outside director). Between 2014 and mid-2016, the share of firms in the first section of the TSE with two or more independent directors rose from 22\% to 80\% (Figure 18). The appointment of outside director(s) in Japan has been found to have a significantly positive impact on a firm's share price and profit margin (Saito, 2009), and to boost their ROE (Investor Impact, 2014). Corporate boards have traditionally been dominated by insiders, notably long-term employees, who play a major role in decisionmaking, thus contributing to a lack of transparency in corporate governance (Kanda, 2013). Moreover, directors tend to focus more on operational execution than on supervision (Ueda, 2015).

Effective evaluation of the board is important, as stated in Principle 4-11-3 of the Code: "Each year the board should analyse and evaluate its effectiveness as a whole... including the self-evaluations of each director. A summary of the results should be disclosed". However, only 55\% of companies had complied with this principle by February 2016 (TSE, 2016). The Code also states that "Boards should establish and disclose independence standards aimed at securing effective independence of independent directors". The effectiveness of independent directors depends on their expertise. A study of over 500 major companies in Japan found that those that appoint independent directors with relevant industry experience have higher total shareholder return, especially when that experience is with competitor firms. However, adding directors from unrelated industries or from academic or legal backgrounds had little effect on shareholder return (Bain \& Company, 2016).

Figure 18. The share of companies with independent directors has increased rapidly

Share of companies on the first section of the Tokyo Stock Exchange as of 14 July 2016

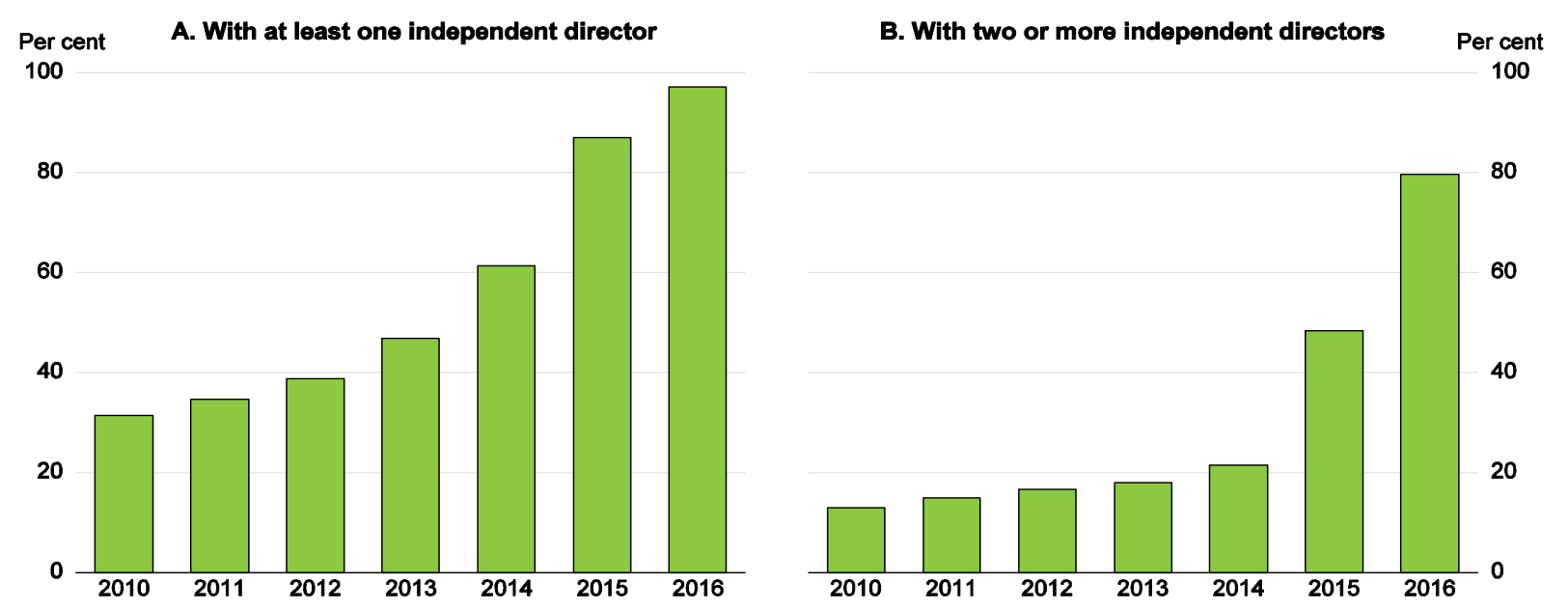

Source: Tokyo Stock Exchange.

A greater role for independent directors would also increase the diversity of corporate boards. In 2013, two-thirds of the firms in the Nikkei 225 had boards of directors composed entirely of Japanese men 
over age 50. Women, foreigners and individuals under age 50 accounted for only $2 \%$ of directors. However, 46 of the 51 women who served on corporate boards in the 225 companies were independent directors (Ueda, 2015). Raising the number of independent directors is likely therefore to bring more diversity in terms of gender, nationality and age to corporate boards, with a positive impact on firm performance. To accelerate the increase, Japan may want to consider introducing quotas, as a number of countries have.

The 2014 Japan Revival Vision also called for lower cross-shareholding, which has "reduced the sense of crisis among management of Japanese companies for many years" and slowed restructuring. Although cross-shareholding, defined as shares in listed companies held by listed companies, has declined significantly since 1990 as main banks sold shares, it still accounts for $11 \%$ of market capitalisation. While cross-shareholding between companies with business ties provides mutual benefits and helps fight takeover bids, it blocks the interests of minority shareholders (Ueda, 2015). The Code requires company boards to re-examine their rationale for cross-shareholdings and disclose their policy and objectives in this regard. Following the implementation of the Code, major banking groups decided to cut cross-shareholdings by around $30 \%$ in the coming three to five years.

Corporate governance reform is not an end in itself - the ultimate purpose is to contribute to greater efficiency and productivity growth and ultimately well-being and inclusiveness in Japan. To achieve this, the business community, the TSE and the government need to support the effective implementation and widespread use of the new framework. To promote changes in behaviour in line with the new framework, the Council of Experts was established in 2015 to monitor the efforts of companies and institutional investors and highlight good practices. One sign of progress is compliance with the principle that annual shareholder meetings should be scheduled for the convenience of investors. Traditionally, such meetings have been concentrated on certain days in June, making it difficult for investors holding shares in multiple firms to attend. The proportion of companies holding their meetings on 29 June - the most popular day fell from $41 \%$ in 2015 to $32 \%$ in 2016. Finally, the rise in the share of foreign ownership of Japanese equities to over $30 \%$ is another driver to improve corporate governance. If Japan is to reap the full benefits of the global capital market, its corporate governance framework arrangements must be credible and adhere to internationally-accepted principles (Isaksson, 2015).

\section{Innovation to promote productivity growth and social inclusion}

Innovation boosts productivity. Japan has a strong innovation base, as measured by patent applications and R\&D spending, which rose from 2.7\% of GDP in 1995 to $3.6 \%$ in 2014, third only to Israel and Korea among OECD countries. In the fifth Science and Technology Basic Plan (2016-20), the government set a target of raising it to 4\% of GDP by 2020 and developing industries at the knowledge frontier. The large labour productivity gap with the top half of OECD countries (Figure 3) and sluggish productivity growth in recent years suggest scope for increasing the return on Japan's investment in innovation. As stressed in the 2015 OECD Economic Survey of Japan, key priorities are improving the quality of research, strengthening international collaboration, including through "open innovation in global networks", and boosting links between R\&D in business, academia and the government.

Business-sector R\&D, which has the greatest impact on TFP growth (Westmore, 2013), is one of the highest in the OECD at $2.8 \%$ of GDP in 2014, making Japan one of the top contributors to the development of disruptive technologies and a world technology leader (OECD, 2016d). The innovation system is dominated by large firms (Figure 19), with little co-operation with universities and government research institutes (GRIs). Indeed, $99.0 \%$ of business-financed R\&D takes place within firms, leaving little room for universities and GRIs at $1.0 \%$ together (Table 3). Consequently, mobility of researchers between the business sector, universities and GRIs is limited. 
Figure 19. $R \& D$ spending is concentrated in large firms in manufacturing In 2013

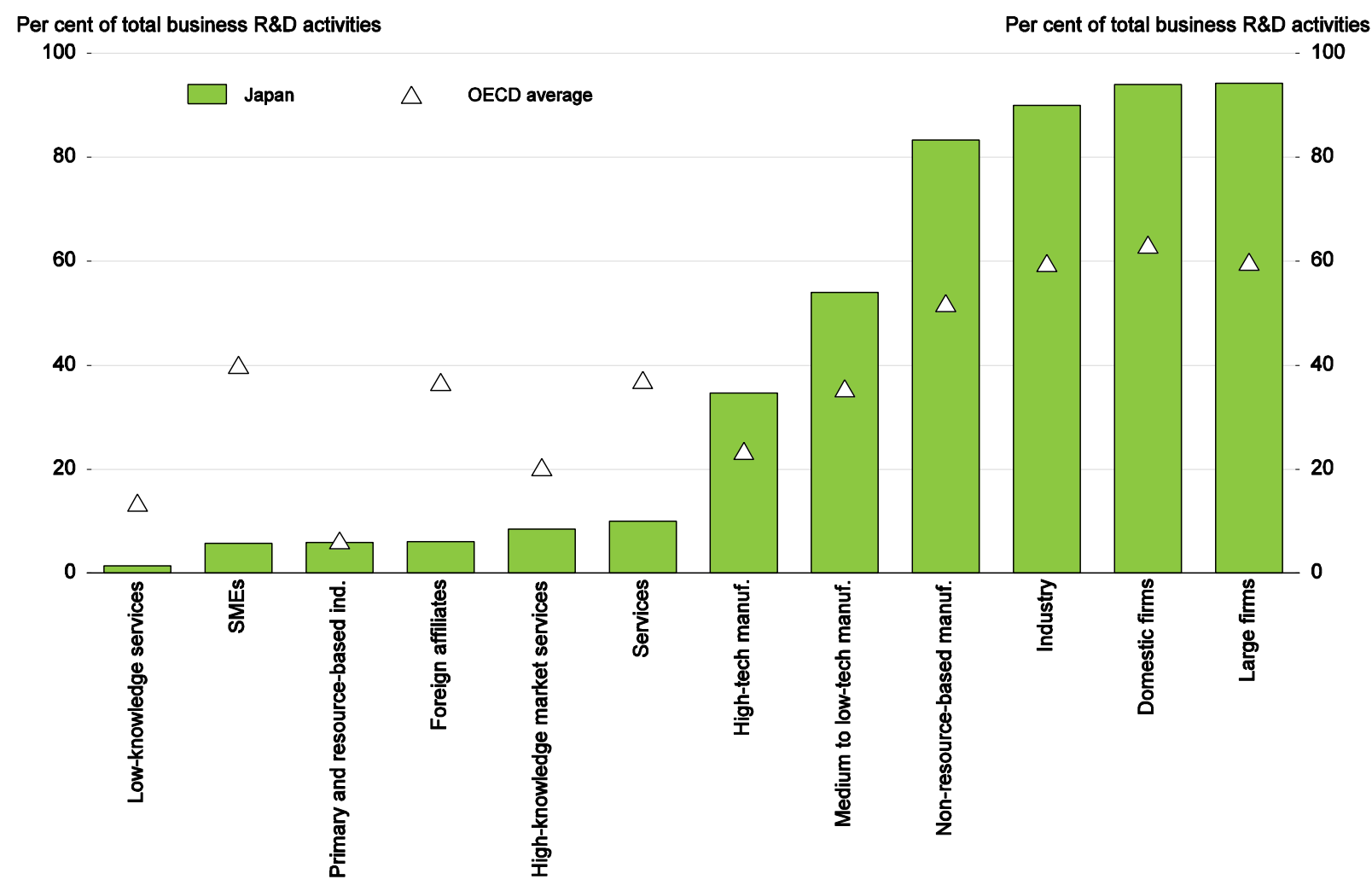

Source: OECD (2016g).

The diffusion of technology is a key to narrowing productivity gaps between firms (OECD, 2015c). Results from firm-level data suggest that R\&D collaboration between universities and firms reduces such gaps (Andrews et al., 2015). Such collaboration is especially important in SMEs and in the service sector,

Table 3. Flows of R\&D funds in 2014

A. R\&D funding

\begin{tabular}{|c|c|c|c|c|c|c|c|}
\hline \multirow[b]{2}{*}{ Source of funding } & \multicolumn{7}{|c|}{ Allocation of $R \& D$ spending by sector performing it } \\
\hline & \multicolumn{2}{|c|}{$\begin{array}{l}\text { Share of total } R \& D \\
\text { spending }\end{array}$} & \multicolumn{2}{|c|}{ Government } & Universities & $\begin{array}{l}\text { Business } \\
\text { enterprises }\end{array}$ & Total \\
\hline Government $^{1}$ & \multicolumn{2}{|l|}{16.7} & \multicolumn{2}{|c|}{54.6} & 40.4 & 5.0 & 100.0 \\
\hline Universities & \multicolumn{2}{|l|}{5.5} & \multicolumn{2}{|c|}{0.6} & 98.8 & 0.6 & 100.0 \\
\hline Business enterprises & \multicolumn{2}{|l|}{77.3} & \multicolumn{2}{|c|}{0.6} & 0.4 & 99.0 & 100.0 \\
\hline Foreign sources & \multicolumn{2}{|l|}{0.5} & \multicolumn{2}{|c|}{5.0} & 2.2 & 92.8 & 100.0 \\
\hline \multicolumn{8}{|c|}{ B. Sector performing R\&D } \\
\hline \multirow[b]{2}{*}{ Sector performing R\&D } & \multicolumn{7}{|c|}{ Funding source for R\&D performed } \\
\hline & $\begin{array}{c}\text { Share of total } \\
\text { R\&D } \\
\text { performed }\end{array}$ & Gov & rnment & Universities & $\begin{array}{l}\text { Business } \\
\text { enterprises }\end{array}$ & $\begin{array}{l}\text { Foreign } \\
\text { sources }\end{array}$ & Total \\
\hline Government $^{1}$ & 9.7 & & 4.6 & 0.3 & 4.9 & 0.2 & 100.0 \\
\hline Universities & 12.6 & & 53.7 & 43.6 & 2.6 & 0.1 & 100.0 \\
\hline Business enterprises & 77.7 & & 1.1 & 0.0 & 98.4 & 0.5 & 100.0 \\
\hline
\end{tabular}

1. Includes private non-profit institutes.

Source: OECD (2017h), OECD Science, Technology and R\&D Statistics (database). 
where $R \& D$ is exceptionally low (Figure 19). R\&D collaboration with universities facilitates technological diffusion by providing smaller firms with access to sources of knowledge, such as advanced machinery or skilled scientists. Thus, policies to boost R\&D collaboration between universities and firms help raise both productivity and inclusive growth (2015 OECD Economic Survey of Japan). In 2016, the government launched the Program for an Open Innovation Platform with Enterprises, Research Institutes and Academia (OPERA) to promote such cooperation at a pre-competitive stage of development, with financing from the business sector and the government.

\section{Increasing international openness}

Barriers to international trade and inflows of foreign direct investment (FDI) can slow productivity gains, hurting inclusiveness. While Japan's explicit barriers to trade and investment are below the OECD average, other barriers are well above (Figure 16). This section considers barriers to imports of agricultural products and Japan's goal of doubling its stock of inward FDI.

Figure 20. Agricultural producer prices in Japan are high

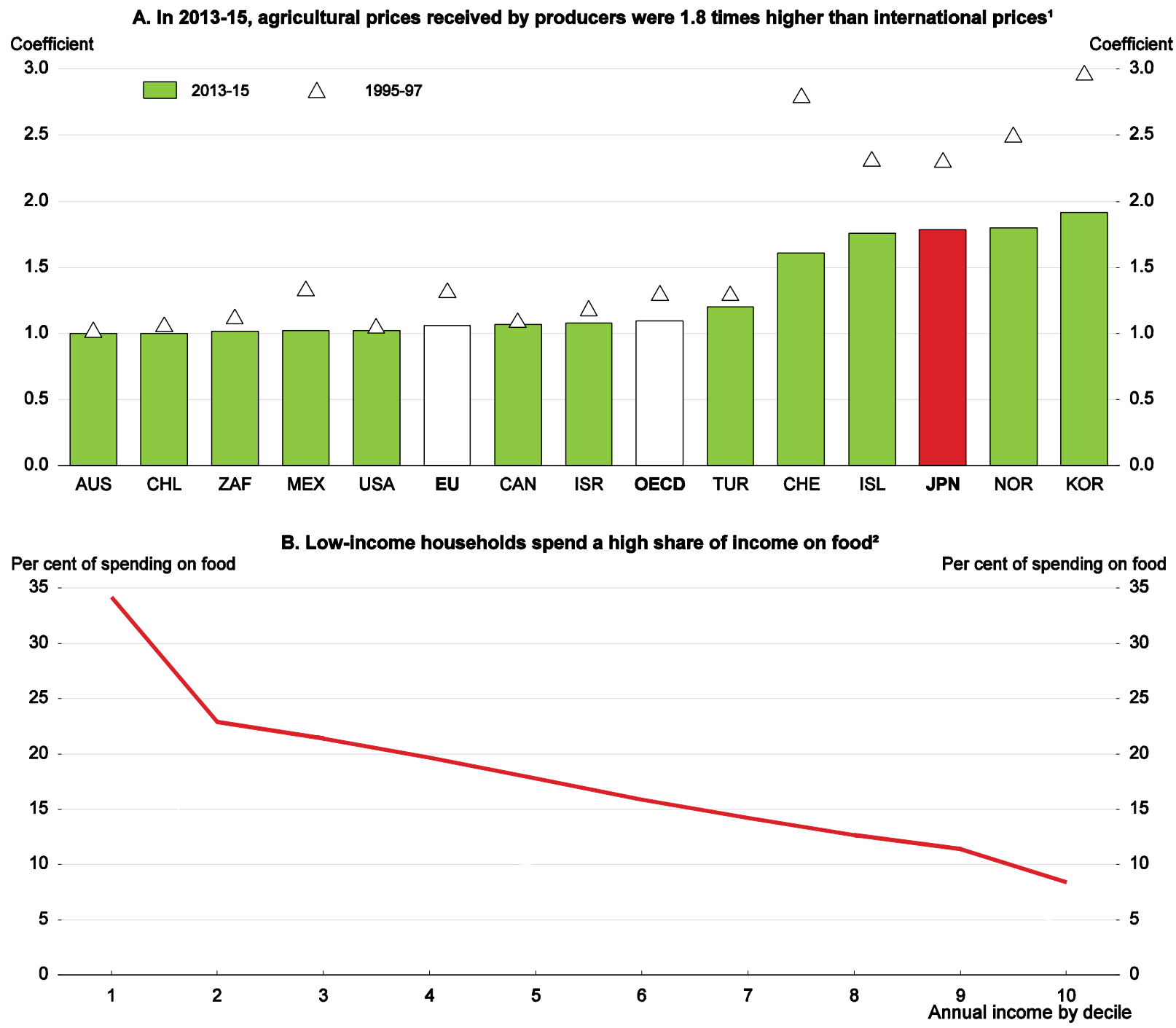

1. The figure shows the Producer Nominal Protection Coefficient (NPC), which is defined as the ratio between the average price received by producers and the border price (both measured at the farm gate).

2. For all households.

Source: OECD (2016a); Ministry of Internal Affairs (2014), Comprehensive Survey on Consumption. 


\section{Agricultural policy and impact on domestic prices}

Barriers to international trade raise prices for consumers and distort production decisions, resulting in a misallocation of resources and lower productivity. In Japan, support for agriculture remains relatively high, averaging $48 \%$ of gross farm receipts in 2013-15, almost three times the OECD average. Market price support (MPS), which is one of the potentially most distorting forms of support, remains the main element of producer support in Japan and is sustained by trade barriers. The high level of protection translates into high prices received by producers, as shown by the Producer Nominal Protection Coefficient (NPC). The NPC of 1.8 indicates that the prices received by producers in Japan were $80 \%$ above international market levels at the farm gate (Figure 20). Japan's NPC is the third highest in the OECD and well above the average of $10 \%$.

Given that the share of income spent on food rises as income falls, high food prices in Japan have a particularly harmful effect on low-income households, aggravating income inequality. The lowest income decile spent $34 \%$ of their income on food (excluding restaurant meals) in 2014 versus only 8\% for the highest decile (Panel B). If agricultural prices in Japan fell to the world level, and this were matched by a decline in food prices in Japan, households would spend much less on food, with low-income households gaining the most.

Japanese agriculture has low productivity due to fragmented farmland, restrictions on entry, an inflexible production and distribution structure and a quota system on rice to maintain the price. Reforms to move towards a market-oriented agriculture sector would boost productivity and promote inclusive growth by reducing the burden of high food prices on low-income families. In 2013, the government decided to phase out the administrative allocation of rice production by 2018, giving farmers more freedom to respond to market signals. However, commodity-specific payments for diversion crops, such as rice for manufacturing and feed, will keep the price of rice high. Further efforts are needed to gradually reduce such payments and narrow the large gap between the international and domestic rice price.

The continued payments for diversion crops are aimed at fully utilising farmland, thereby promoting self-sufficiency. The 2015 Basic Plan on Food Agriculture and Rural Areas, which lays out policy goals for the next 10 years, raised the self-sufficiency targets for the year 2025 from $39 \%$ to $45 \%$ on a calorie supply basis and from $64 \%$ to $73 \%$ on a production value basis. However, Japan should shift the focus from food self-sufficiency to food security based on a multi-faceted approach: i) a more competitive domestic agricultural sector; ii) diversified sources of imports; iii) sufficient emergency food reserves; and $i v$ ) the conservation of an adequate agricultural resource base (2015 OECD Economic Survey of Japan).

Japan's average tariff on agricultural products is $13 \%$, though it exceeds $100 \%$ on some products. Under the TPP agreement that Japan signed in 2015 with 11 other Pacific Rim nations, most agricultural tariffs would have been eliminated, either immediately or over a fixed time period. Japan also made commitments to reduce border measures on some of the most sensitive commodities, including rice, pork, dairy, beef, wheat, and sugar. Japan should continue to pursue regional and bilateral free trade agreements. The thriving specialist livestock and horticulture industries show that Japanese farmers have the potential to be internationally competitive and respond to market opportunities (Jones and Kimura, 2013).

Boosting productivity depends in part on increasing the size of farms through consolidation (OECD, 2016a). Productivity in land-intensive agriculture is low, reflecting the small median size of field crop farms at only five hectares in Japan in 2010, compared to Germany (239 hectares), the United States (486 hectares) and Canada (1 076 hectares) (Bokusheva and Kimura, 2016). The government estimates that land productivity on rice farms of 10 to 15 hectares is double that on farms of one to two hectares. The prevalence of small farms reflects the production quota system, subsidies that make small-scale farming profitable and the complex web of laws governing land ownership, transfer and taxation (Jones and 
Kimura, 2013). Japan has made efforts to promote land consolidation by increasing the land held by "business farmers", who are certified by the authorities, through the creation of a farmland bank and the provision of various types of support for which only business farmers are eligible. However, it is important to address other factors that hamper the growth of more efficient farms. Tax concessions on idled land should be reduced, so as to encourage its productive use.

The rapid ageing of Japan's farmers provides an opportunity to accelerate land consolidation and introduce bold reforms to revitalise the agricultural sector. In 2015, 56.7\% of rice farmers were over 70, while another $32.9 \%$ were between 60 and 69 (Figure 21). Only one-tenth were under age 50.

\section{Figure 21. Japan's farm workforce is elderly}

The age distribution of rice farmers in 2015

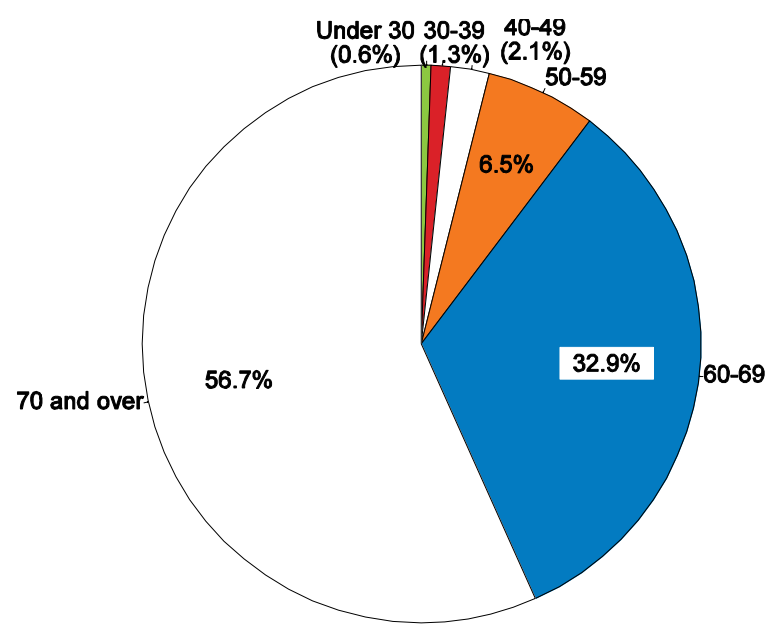

Source: Ministry of Agriculture, Forestry and Fisheries (2015).

\section{Policies to promote inflows of foreign direct investment}

FDI inflows bring important benefits, such as enhancing competition and local technical capabilities. In addition, capital deepening promotes inclusiveness by boosting wages. The Revitalization Strategy set a target of doubling the stock of inward FDI from 18 trillion yen in 2012 to 35 trillion yen in 2020, echoing the 2003 plan to double FDI over five years. The stock rose from 18.0 trillion yen in 2012 to 24.4 trillion in 2015 (Figure 22).

The goal of doubling the stock of inward FDI is challenging. The overriding concerns expressed by foreign firms focus on the need for harmonisation with global systems to address low profitability and high costs in Japan and to improve living conditions for expatriates (Expert Group of the Cabinet Office, 2014; EBC, 2014). A number of specific issues were cited: $i$ ) expanding the market for corporate M\&As, a key channel for FDI; ii) reducing the corporate income tax rate toward the level in other Asian countries (2017 OECD Economic Survey of Japan); iii) bringing Japan's corporate governance framework into line with global standards (see above); iv) reforming unclear administrative practices and unique and rigid standards for certifying consumer goods; $v$ ) liberalising the long and complicated procedures for starting a business; vi) enhancing the flexibility of employment and termination rules; and vii) facilitating the entry of foreign workers (EBC, 2014). 
Figure 22. The level of foreign direct investment in Japan remains low

A. Stock of inward FDI in Japan (in trillion yen)'

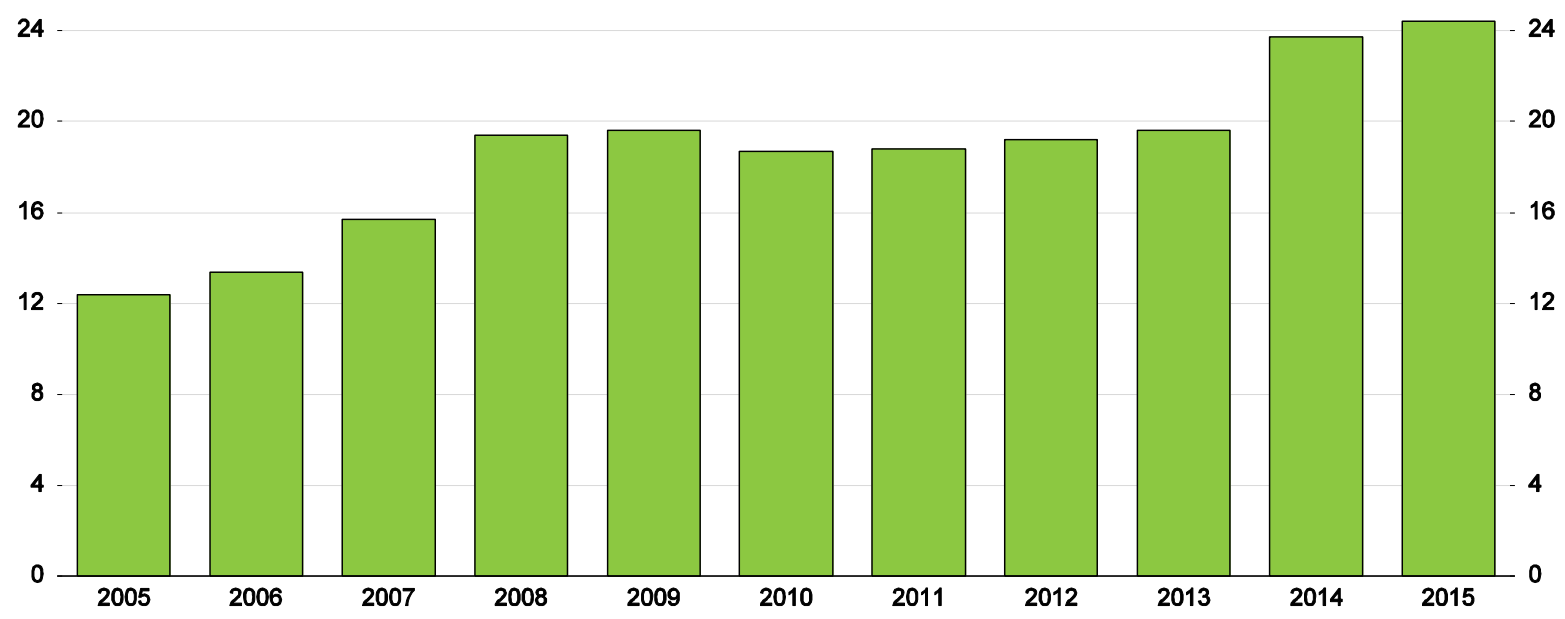

B. International comparison of the stock of inward FDI' (share of GDP in 2015)²

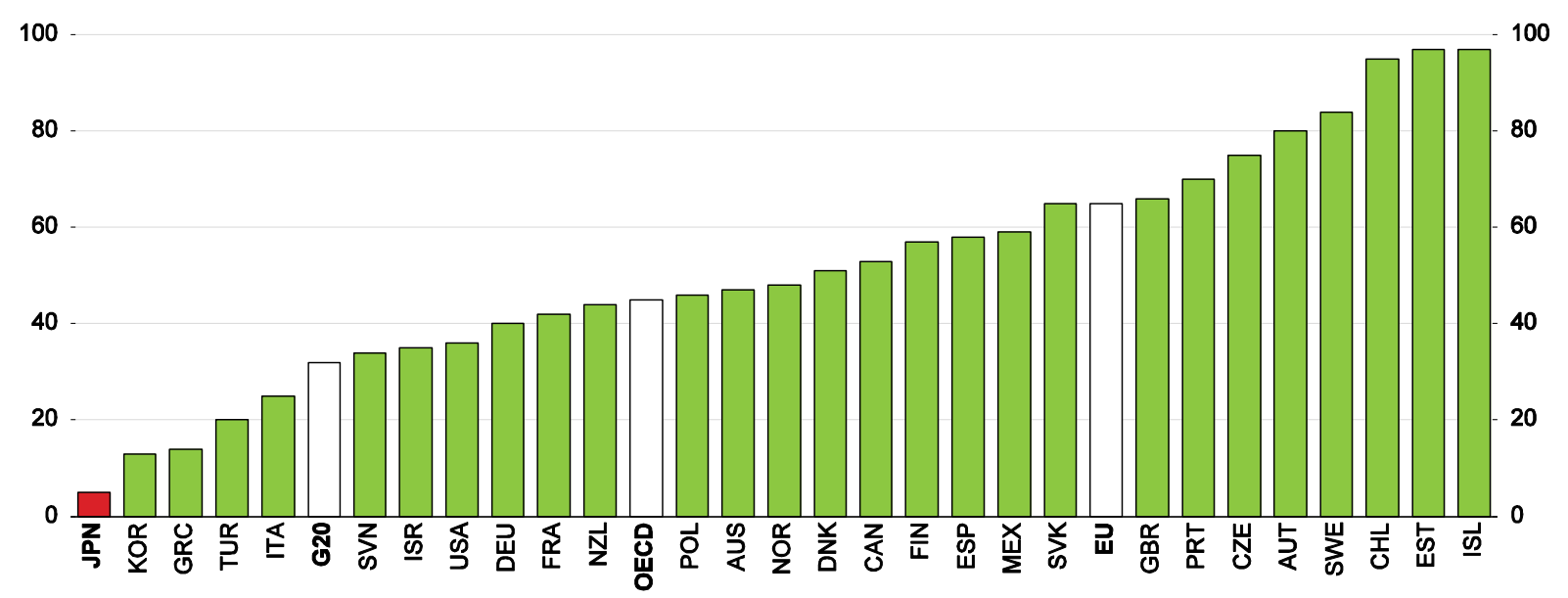

1. Based on BMD4 on a gross basis.

2. Excludes Switzerland (185\% of GDP), Belgium (209\%), Hungary (218\%), the Netherlands (568\%), Ireland (607\%) and Luxembourg (8 313\%).

Source: OECD (2017e), OECD International Direct Investment Statistics (database).

\section{Making the SME sector more dynamic}

SME policy is a key priority for reforms that would promote productivity and inclusive growth. The number of SMEs in Japan fell from 4.8 million in 1999 to 3.8 million in 2015, reflecting in part the difficulty that ageing owners face in finding successors. Nevertheless, SMEs still account for $70 \%$ of employment and more than 50\% of value added. SMEs have long suffered from low productivity and weak profitability. Labour productivity in firms with 20-49 employees is $45 \%$ of that of firms with more than 250 employees, below the OECD average of 55\% (Figure 23). Low productivity in the SME sector is linked to the weakness of services (2015 OECD Economic Survey of Japan), given that three-quarters of SMEs are in that sector. The productivity gap with manufacturing has widened, as productivity stagnated in services (Figure 24). In addition, more than two-thirds of firms with less than 100 million yen (USD 0.87 million) in capital - and thus classified as an SME - reported a deficit in FY 2014. 
Figure 23. Productivity in small firms in Japan is low relative to large firms

Value added per person employed in 2013 relative to that in firms with more than 250 workers $=100$

A. Firms with less than 10 employees

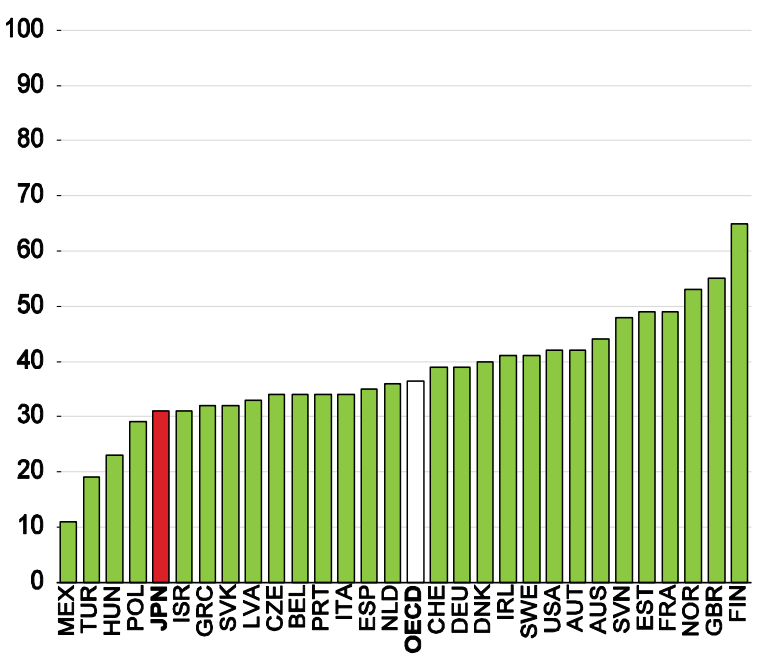

B. Firms with 20-49 employees

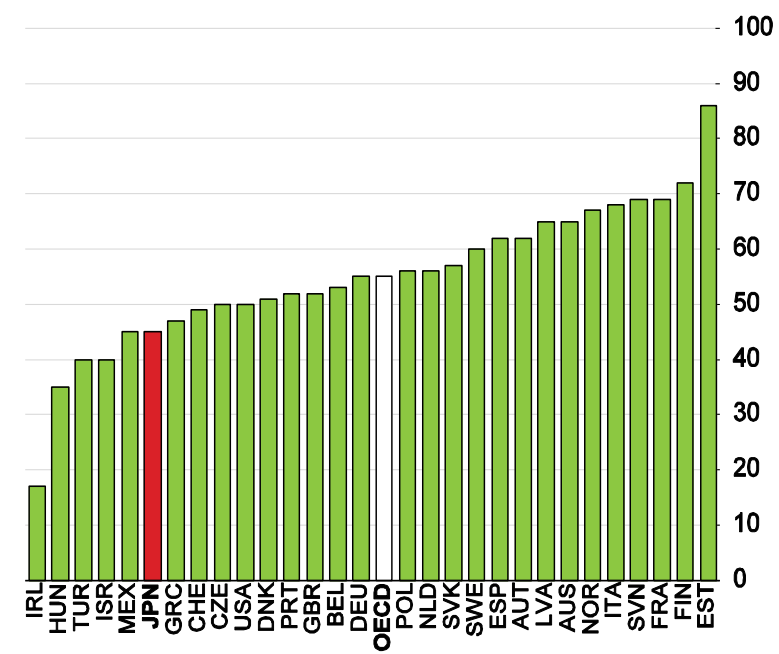

Source: OECD (2016b).

Government lending accounts for about $10 \%$ of SME financing, with another $10 \%$ provided through public loan guarantees (2015 OECD Economic Survey of Japan). SMEs also benefit from a reduced corporate tax rate, and most avoid paying the tax, as owners pay themselves wages large enough for the firm to record a loss. A number of studies show that generous government support delayed restructuring in Japan by keeping non-viable enterprises afloat (Caballero et al., 2008). Public support for SMEs, which account for $99.7 \%$ of registered firms, thus contributed to the low exit rate (Figure 7).

The Basic Law on Small and Medium Enterprises was revised in 1999 to define SMEs as a source of growth, giving policies a focus on two contrasting objectives: $i$ ) revitalisation of regional areas by maintaining employment and starting new firms; and $i$ ) realising Japan's growth potential by promoting new businesses and overseas business expansion (SMEA, 2014a). Boosting the dynamism of the SME sector is an objective of the Japan Revitalization Strategy.

Figure 24. The productivity gap between manufacturing and non-manufacturing has widened sharply

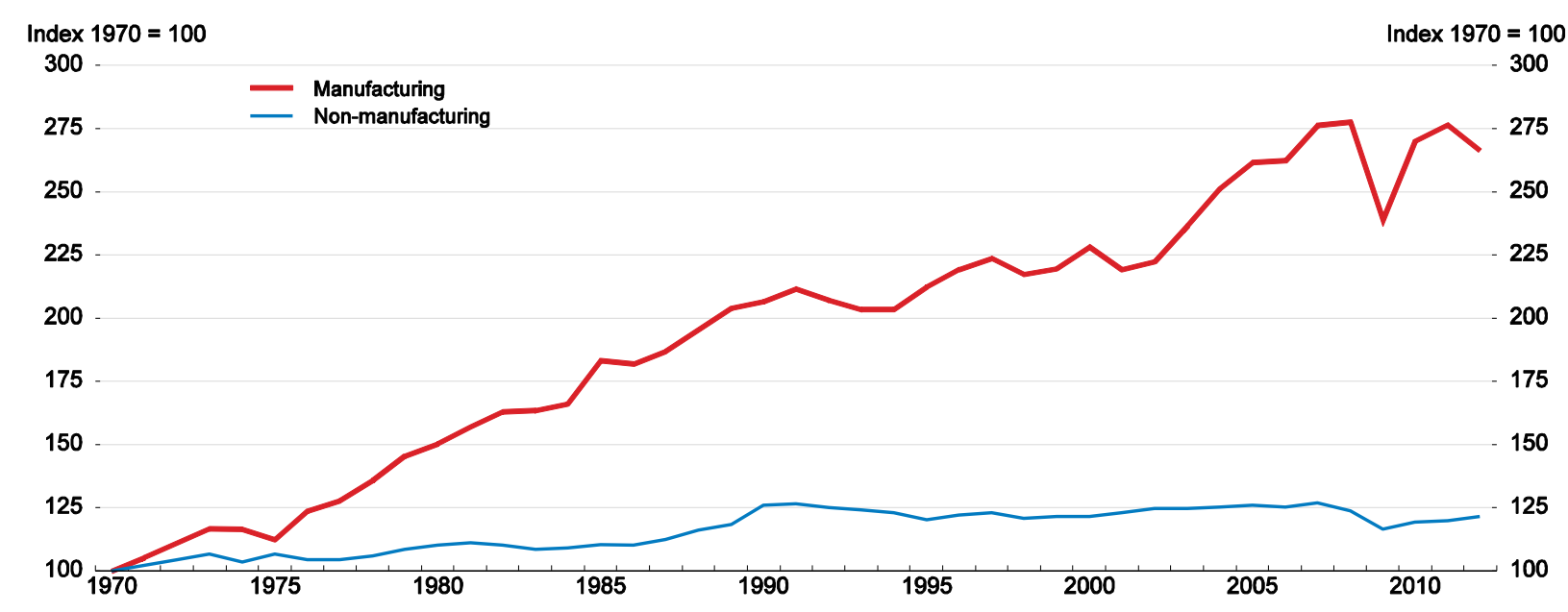

Source: Japan Industrial Productivity Database 2015. 
Outstanding credit guarantees from the government for SME loans fell from a peak of 35.9 trillion yen (7.3\% of GDP) in FY 2009 in the wake of the global financial crisis to 25.8 trillion yen in FY 2015 (Figure 25). In addition, the share of guarantees covering 100\% of loans declined from $69 \%$ to $40 \%$ over that period. Guarantees of $100 \%$ weaken market forces as banks have little incentive to monitor such loans. The government is planning to reform the guarantee system: $i$ ) banks applying for credit guarantees will have to supply loans to SMEs without credit guarantees; and ii) the largest $100 \%$ guarantee scheme (Safety Net Program No. 5) will lower its rate to $80 \%$, making financial institutions liable for $20 \%$. These two reforms will strengthen market forces.

\section{Figure 25. Public credit guarantees for loans to small and medium-sized enterprises have fallen significantly}

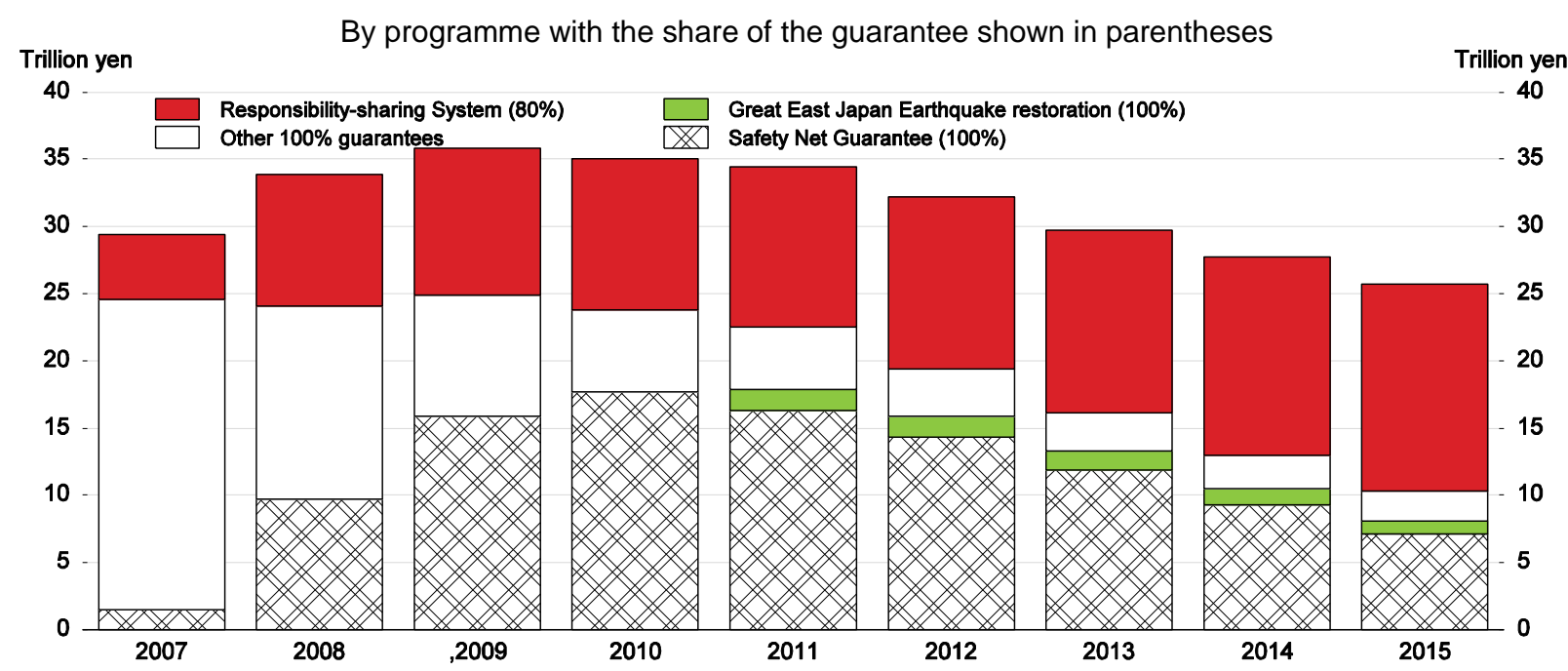

Source: Small and Medium Enterprise Agency.

Despite the decline, government guarantees for loans to SMEs in Japan remain exceptionally high at $5.2 \%$ of GDP in 2015 (Figure 26). However, given the heavy reliance on bank lending for SMEs, the share of SME loans that are guaranteed is around 11\%, compared to $12 \%$ in the United States and 15\% in Korea. As noted above, high levels of public support can delay restructuring by keeping non-viable enterprises afloat. This distorts resource allocation by limiting the scope for entry of new firms and the expansion of innovative firms. Further reducing public support for SMEs is necessary to help achieve the target set in the Japan Revitalization Strategy of raising the firm exit rate to 10\%. Public support for SMEs has other negative side effects. First, it hinders the development of market-based financing (2015 OECD Economic Survey of Japan). SMEs prefer government loans, as they carry low interest rates, while government credit guarantees reduce the burden of collateral and personal guarantees. Financial institutions are content to enjoy stable profits at low risk thanks to credit guarantees, thus reducing incentives to develop credit evaluation and risk management skills for SME lending and to closely monitor borrowers. Public support for SMEs can also increase adverse selection and moral hazard from the side of the banks. Expanding market-based lending requires appropriate infrastructure. The role of collecting and analysing information about SMEs could be played by the Credit Risk Database.

Second, there is little evidence that government financial support improves SME performance (2015 OECD Economic Survey of Japan). A study found that public support increased loan availability for SMEs but did not result in any significant increase in profitability over 2007-12 compared to firms that did not receive benefits (Ono and Uesugi, 2014). Moreover, firms receiving public support recorded larger declines in employment. Another study showed that firms with public credit guarantees were more likely to be in deficit and took longer to repay loans than SMEs without such guarantees (Lam and Shin, 2012). Similar results have been found in other countries (Jones and Kim, 2014). 
Figure 26. Credit guarantees for small and medium-sized enterprises in Japan are exceptionally high

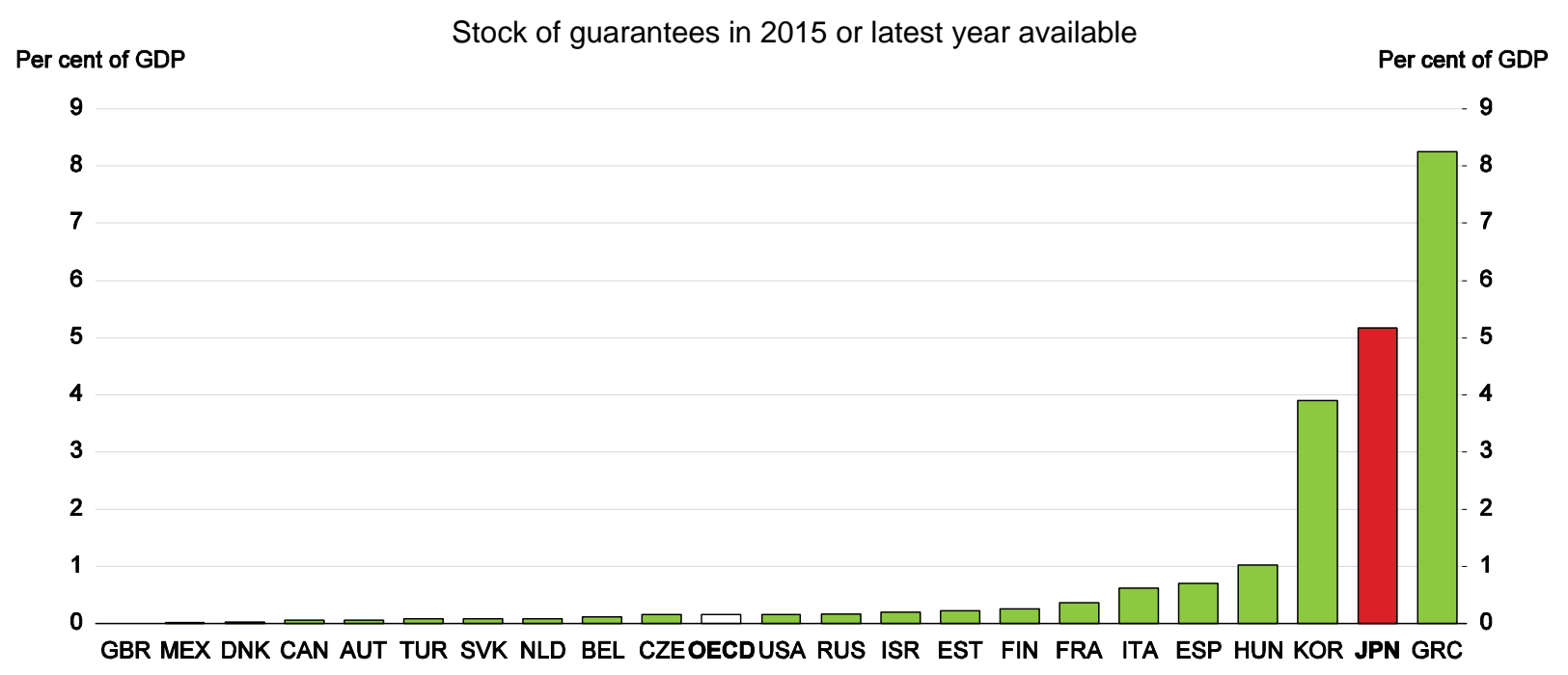

Source: OECD (2017a).

Third, high public support discourages small firms from growing and losing the benefits associated with SME status. In Japan, employment in mature companies (more than ten years old) is similar to that in new start-ups (Figure 9). The reluctance of SMEs to grow is illustrated by trends in their level of capital. Prior to 1999, when the definition of SMEs set the limit of capital at 100 million yen, firms below that threshold were significantly less likely to increase capital than firms above it, suggesting a desire to maintain their SME status. Once the limit on capital in the definition of SMEs was raised in 1999, the share of firms that increased their capital was significantly higher for those below 100 million yen than those above it. The increase was larger the closer the firm had been to the original 100 million yen limit (Tsuruta, 2016). Firms had held back from needed investment until the ceiling on capital to be classified as a SME was raised.

\section{Directions for reform to improve government programmes for SMEs}

Achieving the Revitalization Strategy goal of raising business entry and exit rates to $10 \%$ requires scaling back SME support and making it more market-friendly. Arguably, government intervention should be limited to covering the SME financing gap - the difference between the amount of SME financing that would occur in the absence of market failures and the actual amount of financing - although this is difficult to estimate in practice. The number of SME loans that are guaranteed should be reduced gradually towards the levels in other OECD countries and 100\% credit guarantees should be phased out. Moving the proportion of loans that is guaranteed to $80 \%$ or below would force banks to actively monitor credit risks. A number of countries set the ratio as low as $60 \%$ (IMF, 2012). Moreover, the cost of credit guarantees should be high enough to encourage strong SMEs to seek loans from private sources rather than relying on public support. Even SMEs with high creditworthiness make significant use of public financial institutions and credit guarantees (Minoya, 2012).

In the OECD area, governments are strengthening the focus of SME policy on supporting start-ups, with guarantees and direct lending schemes increasingly targeting young, innovative firms more explicitly (OECD, 2016c). Such an approach should be followed in Japan to allow greater focus on young SMEs, which face the most difficulty in obtaining loans. When initial credit guarantees for start-ups, which cover $100 \%$ of the loan, reach the end of their contract, any renewal of the guarantee should cover a smaller proportion of the loan. 
The 2008 SME Financing Facilitation Act required financial institutions to review the terms of their loans to SMEs in response to requests by the borrowers, in particular by granting grace periods for payments of interest and principal (Yamori, 2014). The amended loans were not classified as nonperforming as long as the SMEs made credible restructuring plans (Endo, 2013). Banks were required to report their response to the authorities and the public (Yamori et al., 2013). Of the more than 4.3 million loans for which SMEs requested modification, 97\% was approved by banks. The cumulative amount of modified loans reached 120 trillion yen (22\% of GDP) (Ono and Uesugi, 2014). Although the law ended in 2013, the Financial Services Agency has continued to encourage financial institutions to modify the terms of loans to SMEs (2015 OECD Economic Survey of Japan). Supervisors should not pressure financial institutions to modify loans in response to requests from SMEs. Instead, the focus should shift from providing a safety net to promoting the restructuring of non-viable firms through efficient markets. This could be encouraged by requiring financial institutions to conduct regular credit reviews of SMEs, publicly announce the results, and prepare restructuring plans for non-viable firms, an approach adopted in Korea.

\section{Breaking down labour market dualism}

Non-regular employment, a category that includes fixed-term, part-time and dispatched workers (i.e. workers sent from private employment agencies), rose sharply from 9.7 million $(20.3 \%$ of total employment) in 1994 to 18.1 million $(35.2 \%)$ in 2012. The upward trend has continued and by the third quarter of 2016, the number had topped 20 million, accounting for $37.5 \%$ of employment. Non-regular employment is concentrated among women, who accounted for $68 \%$ of non-regular workers in 2015 (Figure 27). Of women working as employees, 56\% are non-regular workers. Among men, non-regular employment is concentrated among those under age 35 and those over age 55.

Figure 27. Non-regular employment is concentrated among women

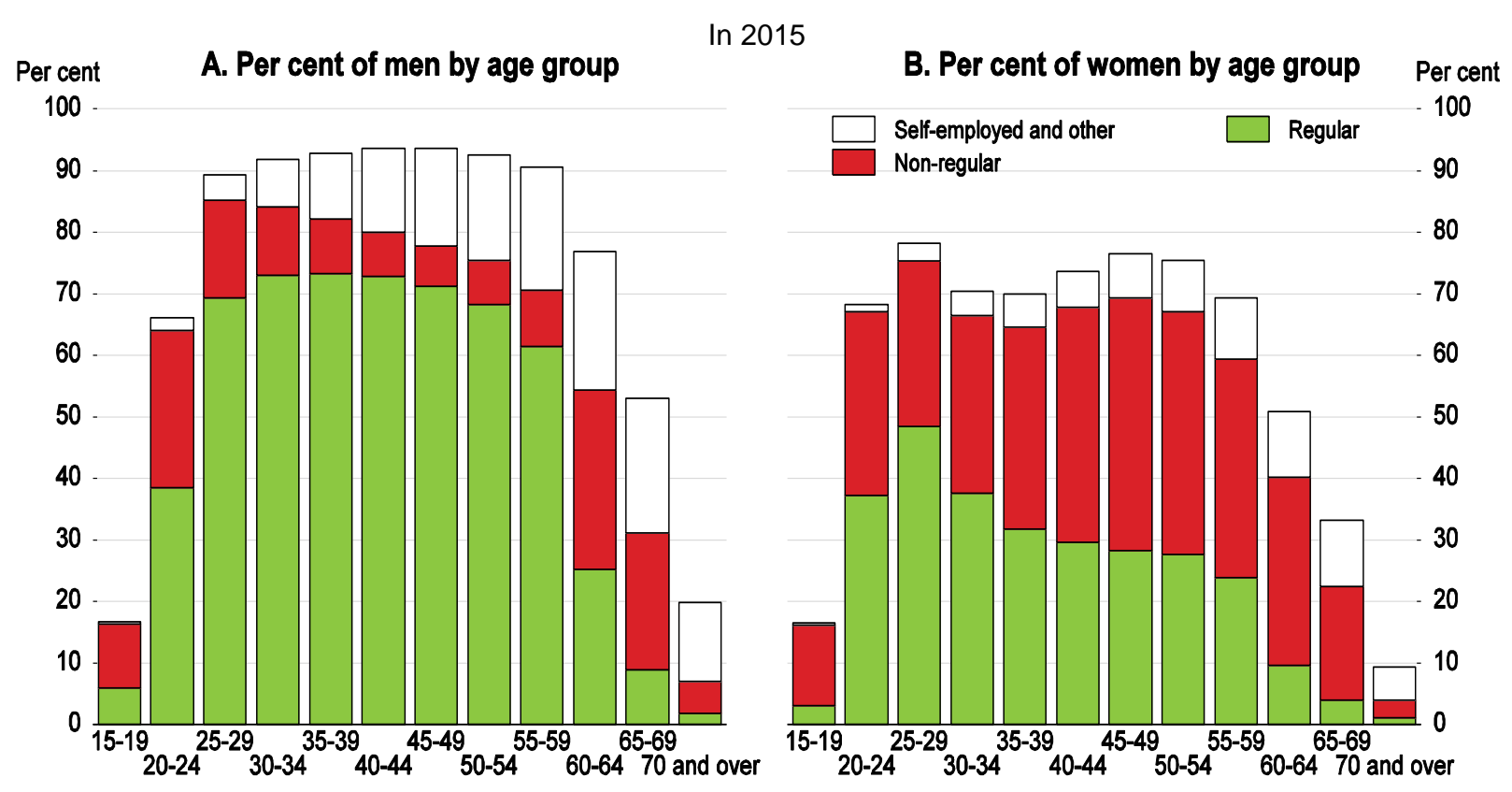

Source: Ministry of Internal Affairs and Communications.

Dualism undermines productivity, as non-regular workers receive less training from firms, which have little incentive to invest in workers who are not permanent. Studies of other countries find that dualism results in less human capital and lowers productivity growth (Aoyagi and Ganelli, 2013). A recent OECD study shows that relaxing employment protection raises aggregate productivity through more 
efficient resource allocation, thereby reducing the gap between leading and lagging firms (Andrews et al., 2016).

Dualism also worsens inequality and poverty due to wide wage gaps. On an hourly basis, non-regular workers earn around $60 \%$ as much as regular workers (excluding bonuses). The wage gap increases with age. In the 50-54 age group, regular workers earn twice as much as non-regular workers (Figure 28). This comparison understates the gap as it excludes bonus payments, which most non-regular workers do not receive. Among households in the 45-49 age group, the income of those headed by a regular worker was four times higher on average than for those headed by a non-regular worker (Panel B).

Figure 28. The wage gap between regular and non-regular workers is large

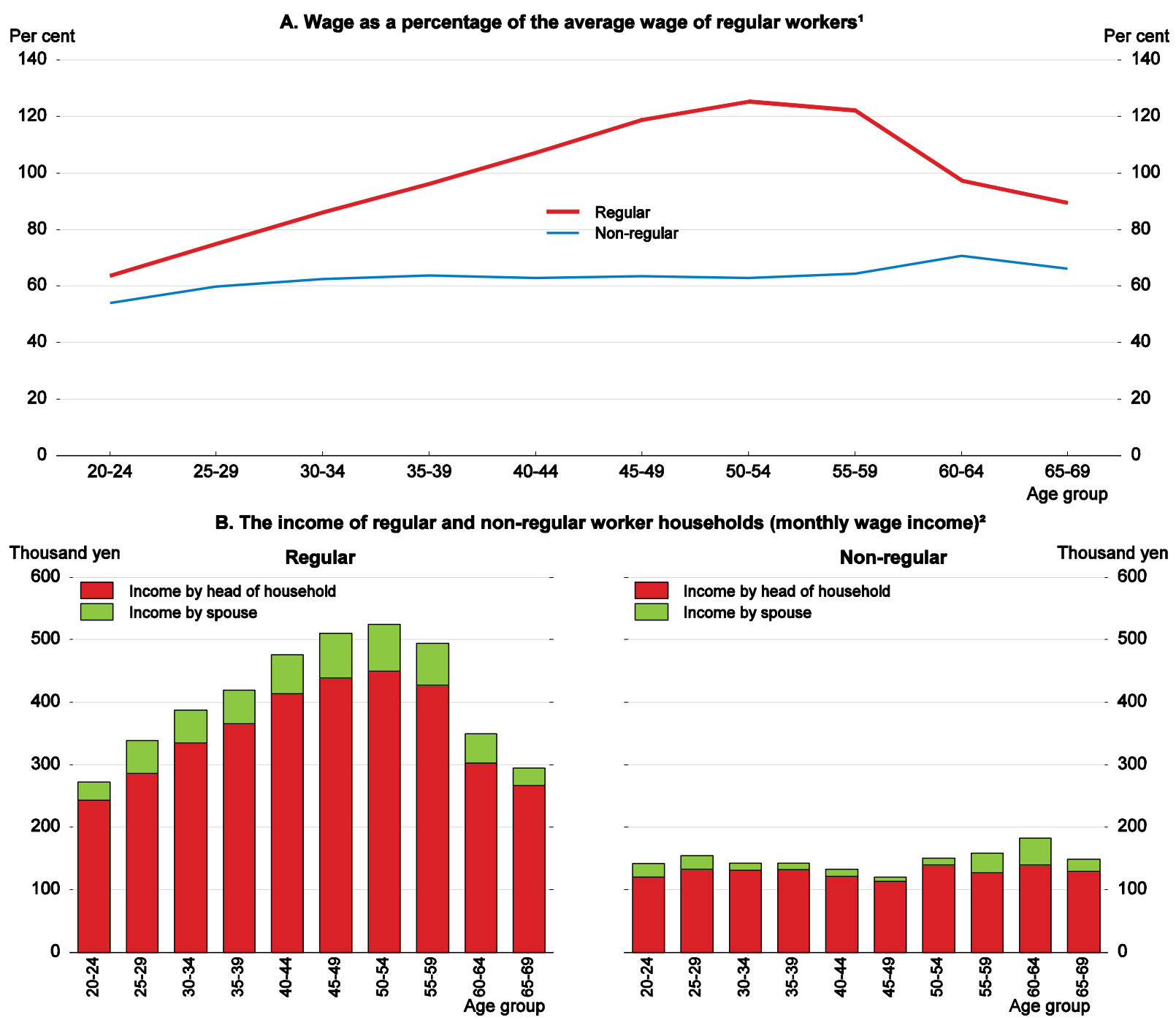

1. Hourly wage in June 2015 , excluding overtime payments and bonuses. Only $30 \%$ of part-time workers, who account for $70 \%$ of non-regular employment, receive bonus payments so the gap in take-home pay is even larger.

2. The survey covers households with two or more members. Bonus payments, which are paid primarily to regular workers, are included.

Source: MHLW, "Basic Survey on Wage Structure 2015"; MHLW (2014).

Low pay for non-regular workers results in high relative poverty rates (Table 4). According to a government survey, 49\% of non-regular workers are the main earner in their household (MHLW, 2011). Among households with one earner, the poverty rate is $5 \%$ if the husband is a regular worker and $35 \%$ if he 
is a non-regular worker. The rising number of non-regular workers is driving up the number of social welfare recipients (Jones and Fukawa, 2017). The negative consequences of dualism are exacerbated by limited mobility in a segmented labour market, in contrast to many other OECD countries, where temporary work is frequently a stepping stone to permanent employment.

Table 4. Non-regular worker households suffer from a high poverty rate

Relative poverty rate by employment status of spouses ${ }^{1}$

\begin{tabular}{lcccc}
\hline & \multicolumn{3}{c}{ Wife (\%) } \\
\cline { 2 - 5 } Husband (\%) & Regular & Non-regular & Self-employed & Not employed \\
\cline { 2 - 5 } & & 3 & 3 & 5 \\
Regular & 1 & 19 & 16 & 35 \\
Non-regular & 7 & 16 & 13 & 23 \\
Self-employed & 5 & 38 & 21 & 47 \\
Unemployed & 8 & & \\
\hline
\end{tabular}

1. The data are based on a survey of nearly 10000 people. Relative poverty is defined as an income below $50 \%$ of the national median.

Source: Higuchi (2013).

Breaking down labour market dualism is essential to boost productivity and achieve inclusive growth. Prime Minister Abe said that the goal is "eliminating the expression 'non-regular workers' from our country" (Prime Minister's Office, 2016). The government has taken steps to address dualism:

- The Labor Contracts Act revision in 2013 requires that fixed-term contracts renewed repeatedly be transformed to open-ended contracts once a worker exceeds five years at the same firm, if the worker requests. The risk is that workers who previously would have been able to continue working by renewing fixed-term contracts will instead be forced out, as has occurred in some OECD countries with similar limits on fixed-term contracts (OECD, 2016e; Tsuru, 2012).

- The government announced in 2013 that it would achieve a "policy shift from 'over protection' type to 'support for labour mobility' type". In practice, this meant that Labor Mobility Support Subsidies have surpassed Employment Adjustment Subsidies. While the shift in emphasis is welcome, subsidies need to be carefully designed so as to encourage adequate take-up rates while avoiding large deadweight and displacement effects (OECD, 2015a).

- The government has launched an initiative for "equal pay for equal work" to eliminate the wage gap between regular and non-regular workers. The government announced draft guidelines last December that will be attached to the Labor Contract Law, the Part-time Workers' Law and the Worker Dispatching Act. In practice, it is difficult for workers to take complaints of differential treatment that is less favourable to the court given their limited information. Few OECD countries have laws that explicitly require that temporary workers be paid the same wages as equivalent permanent workers, given the difficulty of proving that their treatment is discriminatory (OECD, 2016e).

While laws to end discrimination are always welcome, breaking down dualism requires reforms aimed at the factors underpinning dualism. Two key factors encouraging firms to increase non-regular employment are the importance of cutting labour costs and enhancing employment flexibility. In addition to lower pay, non-regular workers receive less coverage by social security, which reduces employer social insurance contributions. Around a third of non-regular workers are not covered by employment insurance and about half are excluded from Employees' Pension Insurance (EPI) and firm-based health insurance. In addition, $70 \%$ of part-timers do not receive bonus payments and $90 \%$ do not receive the lump-sum 
retirement benefit paid by firms. In 2016, EPI was extended to around 250000 non-regular workers, which is a step in the right direction.

Firms also hire non-regular workers to increase employment flexibility due to the employment protection accorded to regular workers. The Labor Contract Act states that any dismissal of workers that "lacks objective, reasonable grounds and is not considered to be appropriate in general societal terms, [shall] be treated as an abuse of power and be invalid". The law itself is not especially stringent and Japan is ranked in the lower half of OECD countries in its index of employment protection for regular workers. However, in practice, employment protection is high enough to prompt firms to raise the share of nonregular workers in their employees. For example, in the Global Competitiveness Index, restrictions on hiring and firing of workers in Japan is ranked as the tenth most severe among OECD countries (World Economic Forum, 2017). The very general formulation in the Labor Contract Law allows the legal system considerable discretion in applying the law. Judicial precedents have established four criteria to determine whether employment adjustment as a result of corporate downsizing can be deemed an abuse of power by the employer:

- The employer must establish the economic necessity for reducing its workforce.

- The employer must demonstrate that all reasonable efforts to avoid dismissals have been made.

- The employer must establish reasonable and objective criteria for selecting which workers will be dismissed.

- The employer must show that the overall dismissal procedure is acceptable, for example by showing that unions or worker representatives were adequately consulted.

It is "exceedingly difficult to judge the validity of dismissal" (JETRO, 2016), as these criteria leave considerable room for interpretation (OECD, 2015a). If an employer is judged to have failed to meet the criteria, the dismissal is rendered invalid. Such cases cannot be settled through monetary means (Tsuru, 2012), as the government rejects the notion that employers can dismiss workers by just paying money to them. Instead, the court usually orders reinstatement of dismissed workers with back pay. There is no time limit on when former workers may make a claim of unfair dismissal. In sum, employers face great uncertainty in trying to dismiss regular workers, thus prompting them to turn to non-regular workers.

Against this backdrop, a comprehensive strategy is needed to break down labour market dualism by increasing the coverage of social insurance and upgrading training programmes for non-regular workers, raising the minimum wage and reducing employment protection for regular workers, in part by increasing transparency (2015 OECD Economic Survey of Japan). Reducing employment protection promotes growth-enhancing labour mobility and economic dynamism more generally (OECD, 2015c). As a first step to reduce uncertainty, the government should set specific monetary compensation for dismissed workers in order to create a "highly foreseeable dispute settlement system", but has not yet reached a conclusion.

In addition, employment protection for regular workers should be reduced, although this is difficult to implement in practice. In some European countries, it has been achieved through grandfathering - allowing current workers to keep current levels of employment protection but not newly-hired workers (OECD, 2017c). Another option would be to compensate regular workers for a reduction in employment protection through reforms that also accomplish the goal of improving work-life balance. For example, regular workers could be given additional leave, the right to refuse involuntary relocations and a reduction in overtime work. Such measures would reduce the incidence of "karoshi" (death by overwork), an issue of concern in Japan. Most importantly, the government must ensure adequate income and re-employment support to displaced workers. 


\section{Human capital and skills}

Japan is a top performer in development of skills, but deploying them effectively remains a challenge. Japan consistently ranks among the best performers in the OECD Programme for International Student Assessment (PISA), which tests the skills and knowledge of 15 year-old students, and the share of adults with a tertiary education is the second highest in the OECD. Japan ranked first in the OECD Survey of Adult Skills (PIAAC) in both literacy and numeracy skills of adult workers. While Japan excels in developing skills, it falls short in using skills at work, which is equally important if these high levels of skill proficiency are to translate into economic growth and productivity. For example, while Japan has the highest level of literacy and numeracy skills, the use of reading skills in the work place is close to the OECD average, while the use of numeracy skills is below average and the use of writing skills is just above average. Furthermore, $10 \%$ of workers are in jobs for which their literacy competencies are higher than required (OECD, 2016d). A significant share of Japanese employers are not making the best use of their workforce's competencies.

A key problem is that female workers who attain a high level of qualification often work in jobs for which they are overqualified, particularly as non-regular workers. The PIAAC survey indicates that women in Japan face the highest probability of being overqualified at 32\%, compared to the average of $20 \%$ in the countries that participated in the survey (OECD, 2013d). Overall, about one-fifth of Japanese workers report a mismatch between their existing skills and those required for their job, with about $15 \%$ overskilled and 5\% under-skilled (Figure 29).

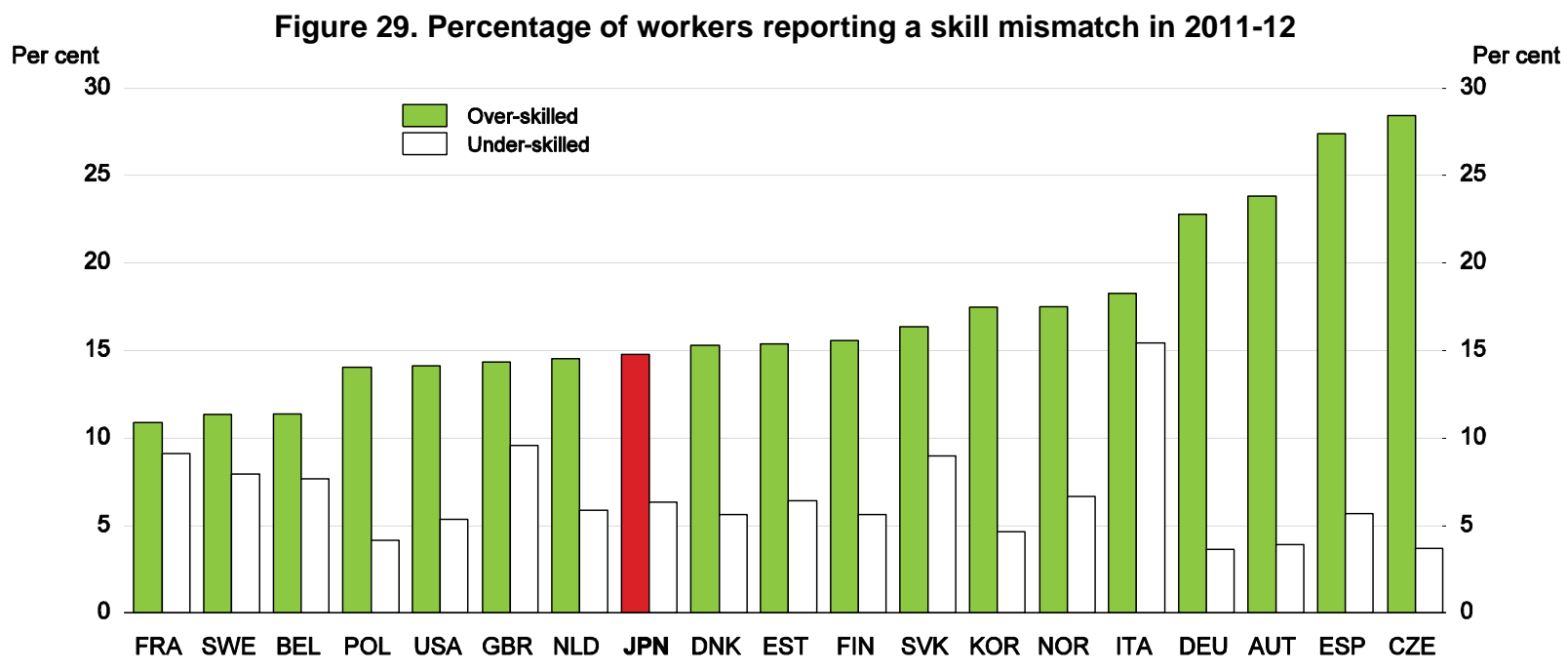

Source: Adalet McGowan and Andrews (2015).

Skill mismatch and aggregate productivity are related through two channels: the impact on withinfirm productivity and on the allocation of labour resources across firms. Trapping skilled labour in relatively low productivity firms makes it more difficult for more productive firms to attract skilled labour and gain market share. Mismatch thus slows the growth of new innovative firms, lowering aggregate labour productivity. Reducing the level of mismatch to the best practice in the OECD in each industry would boost overall labour productivity by around 4\% in Japan (Adalet-McGowan and Andrews, 2015). The negative effect of mismatch on resource allocation more than offsets any productivity benefit that may accrue to the firms that employ over-skilled workers (Adalet McGowan and Andrews, 2015). However, an even greater untapped supply of high-quality human capital stems from the fact that $22 \%$ of highly proficient adults are inactive, mostly reflecting the relatively low employment rates of Japanese women with higher education. 


\section{Ensuring that digitalisation promotes inclusive growth}

Human skills are especially important to adapt to the digital economy. Governments, businesses and individuals are increasingly moving social and economic activities to the Internet as the diffusion and use of digital technologies increase. Digitalisation is a transformational change, unleashing new business models and modes of social interaction that promise to spur innovation, increase productivity and improve services in a wide range of areas (Scarpetta and Wyckoff, 2016). Digitalisation is expanding the gap between leading and lagging firms. In ICT-intensive sectors, global frontier firms increase their market share more rapidly, and productivity divergences are deeper (Andrews et al., 2016). At the same time, digitalisation can promote inclusive growth by creating better access to quality education and new opportunities for skill development (OECD, 2016j).

Japan has a vibrant Information and Communications Technology (ICT) sector, which accounted for $7 \%$ of GDP in 2013, the second highest in the OECD. It is particularly strong in ICT manufacturing, ranking fourth among OECD countries in 2013 with a world export market share of 4\%. Japan is a top player in a number of ICT-related technologies, ranking fifth in the OECD in terms of business R\&D in ICT as a share of GDP. Moreover, it has the second-highest penetration of mobile broadband in the OECD, at over $120 \%$ (OECD, 2015b).

However, Japanese firms have underinvested in ICT compared to some other major economies, reflecting a number of factors: $i$ ) Japan has a relatively small share of start-up firms, which typically are large investors in ICT; and ii) the incentive to invest in ICT, which is often used to reduce labour inputs, is less attractive in Japan, given high employment protection that makes it difficult to adjust employment (Fukao, 2012). Japan faces challenges to stimulate the uptake and effective use of ICT by businesses to promote ICT-driven growth. The share of enterprises with a broadband connection was the second lowest in the OECD in 2014 (Figure 30). The share is lowest among small firms. In a 2015 survey, small firms, with an average workforce of 89 , invested only $1.9 \%$ of their value added in ICT, only half as much as large firms (Table 5).

Figure 30. Japan is lagging in the share of firms with broadband connectivity In 2014

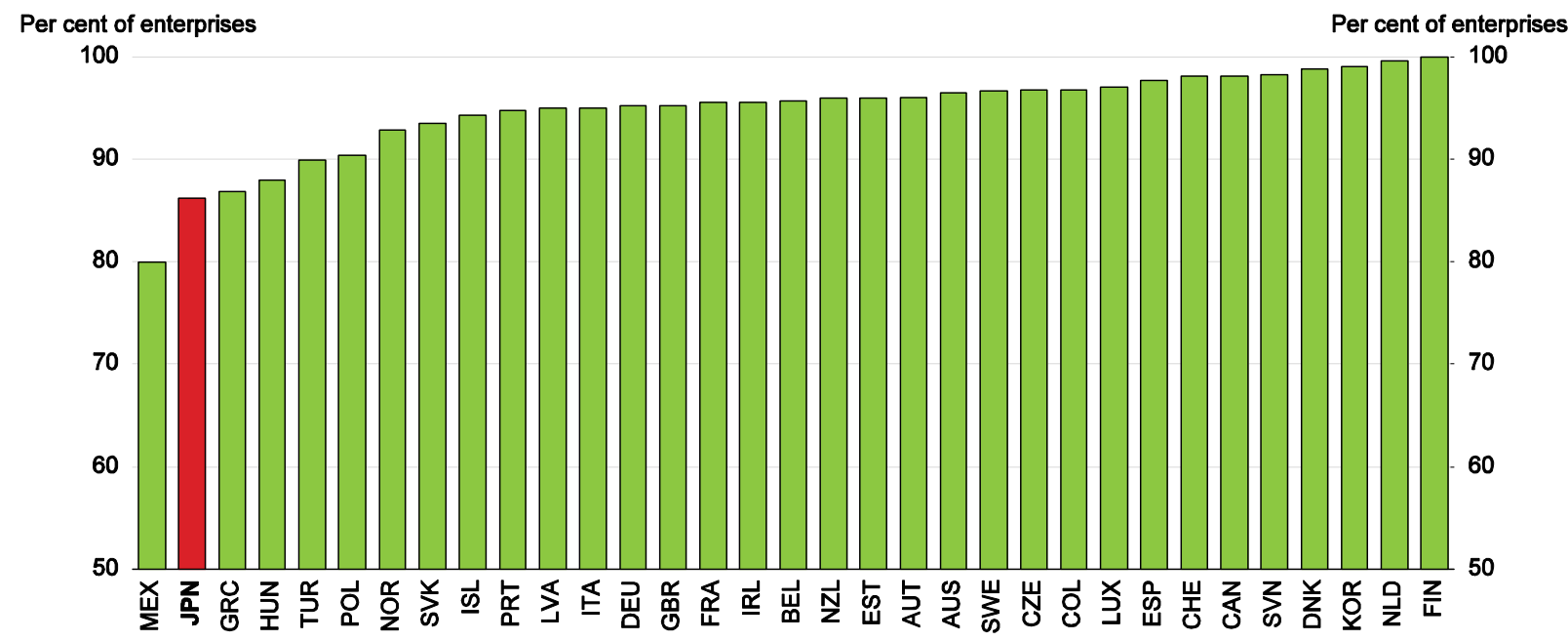

Source: OECD (2015b).

Japan's ambitious 2013 Declaration to be the World's Most Advanced Information Technology (IT) Nation aims to achieve this goal by 2020. Acknowledging that Japan has not been able to fully utilise IT, 
the government launched a strategy to make IT an engine of growth by encouraging the creation of new and innovative industries and services (Strategic Headquarters, 2013). The government also expects IT to facilitate increased employment of women and older persons, in part by improving work-life balance.

Table 5. Investment in Information and Communication Technology is low in small firms

Averages based on a survey of firms

\begin{tabular}{|c|c|c|}
\hline Firm size & Number of employees & ICT Inputs ${ }^{1}$ \\
\hline Large & 1783 & $3.8 \%$ \\
\hline Intermediate & 472 & $2.8 \%$ \\
\hline Medium & 201 & $2.2 \%$ \\
\hline Small & 89 & $1.9 \%$ \\
\hline Total & 307 & $2.6 \%$ \\
\hline
\end{tabular}

1. As a percentage of value added in 2015.

Source: Fukao et al. (2015).

As is typical with new technology, digitalisation can be disruptive, with wide-ranging impacts on work and production. The pace of the digital transformation is uneven with some socio-demographic groups lagging behind, with differences linked primarily to age, education and income levels. Failure to adequately address these issues could lead to economic inefficiency and greater inequality. A coherent and comprehensive policy approach is therefore necessary to harness the benefits of digitalisation to ensure inclusive growth in Japan.

To make IT an effective driver of productivity and narrow the digital divide, the 2013 strategy contains a number of elements. First, it aims at digitalising the educational environment by investing in infrastructure, including software and hardware, beginning in primary school. In 2012, over half of 15 year-old students did not have an Internet connection or did not make use of it in school, compared to the OECD average of $29 \%$ (OECD, 2015g). Digitalising education requires developing teachers' capacity to take full advantage of a digital environment. In 2014, Japan launched a four-year plan, totalling 671 billion yen (USD 5.9 billion) to equip schools with more computers (for both teachers and students), electronic blackboards, wireless LANs and education software, and to employ ICT assistants at schools.

Second, the strategy will increase and enhance IT literacy for all, from children to older people. In Japan a surprisingly large proportion of the adult population, especially older people, have relatively poor IT skills. The OECD Survey of Adults Skills found that $10.2 \%$ of adults in Japan had no computer experience and $10.7 \%$ failed the IT core assessment, meaning they lacked the most elementary computer skills (such as the ability to use a mouse). Both shares are relatively high (OECD, 2016d). The share of adults in these categories rises to $21.2 \%$ for the $45-54$ age group and to $40.9 \%$ for 55-64 year-olds, the fourth highest among participating countries. Consequently, the use of ICT at work is lower in Japan than in other countries for all age groups. Moreover, in 2013, 83\% of individuals aged 6 years and older used the Internet, but only $74 \%$ used it daily, and $57 \%$ used it to make online purchases (OECD, 2016d). Government efforts to increase IT literacy, including among the 16-24 age group, whose IT problemsolving skills are relatively low, are a priority. In the 2016 follow-up to the Declaration to be the World's Most Advanced IT Nation, the government stated that it will consider policies to develop human resources to drive IT utilisation at private-sector companies.

Third, the strategy aims to reform the regulatory environment for IT. Many rules and regulations were established prior to the IT revolution and thus need to be revised to foster IT-driven growth. 


\section{Box 1. Main policy recommendations for boosting productivity for inclusive growth}

\section{Key recommendations}

- $\quad$ Facilitate the exit of non-viable firms by reducing the use of personal guarantees.

- Promote second chances for failed entrepreneurs by making the personal bankruptcy system less stringent.

- Increase the productivity of SMEs by strengthening R\&D links between firms and universities.

- Implement the planned reform of the Credit Guarantee System to strengthen market forces and keep public guarantees of SME loans on a downward trend.

- Break down labour market dualism by relaxing employment protection for regular workers and expanding social insurance coverage and training for non-regular workers.

\section{Further recommendations}

- Make greater use of the Guidelines for Personal Guarantees Provided by Business Owners to expedite outof-court settlements for failed SMEs.

- $\quad$ Promote entrepreneurship by enhancing the availability of education, training and financing, particularly for women.

- Work in tandem with the stock exchange and the private sector to promote compliance with the principles contained in the new Stewardship and Corporate Governance Codes.

- Scale back commodity-specific agricultural subsidies and promote farm consolidation to lower production costs and strengthen market forces in the farming sector.

- $\quad$ Continue to pursue regional and bilateral free trade agreements.

- $\quad$ Focus SME support on overcoming market failures that limit private financing rather than supporting mature firms.

- Encourage FDI inflows by addressing problems in the M\&A market, corporate governance, regulation and employment flexibility.

- Focus regulatory reform on administrative burdens on start-ups and regulatory protection of incumbents to encourage firm creation.

- Expand the use of ICT in education to prepare for the digital revolution.

- $\quad$ Raise the minimum wage.

- Use the new guidelines in labour laws to reduce discrimination against non-regular workers. 


\section{REFERENCES}

Abe, N. and S. Shimizutani (2007), "Employment Policy and Corporate Governance - An Empirical Comparison of the Stakeholder and the Profit-Maximization Model", Journal of Comparative Economics, Vol. 35.

Adalet McGowan, M. and D. Andrews (2015), "Skill Mismatch and Public Policy in OECD Countries", OECD Economics Department Working Papers, No. 1210, OECD Publishing, Paris, http://dx.doi.org/10.1787/5js1pzw9lnwk-en.

Adalet McGowan, M. and D. Andrews (2016), "Insolvency Regimes and Productivity Growth: A Framework for Analysis", OECD Economics Department Working Papers, No. 1309, OECD Publishing, Paris.

Adalet McGowan, M., D. Andrews and V. Millot (2017), "The Walking Dead? Zombie Firms and Productivity Performance in OECD Countries", OECD Economics Department Working Papers, No. 1372, OECD Publishing, Paris.

Andrews, D., C. Criscuolo and C. Menon (2014), "Do Resources Flow to Innovative Firms? Cross-country Evidence from Firm-level Data", OECD Economics Department Working Papers, No. 1127, OECD Publishing, Paris.

Andrews, D., C. Criscuolo and P. Gal (2015), "Frontier Firms, Technology Diffusion and Public Policy: Micro Evidence from OECD Countries", OECD Productivity Working Papers, No. 2, OECD Publishing, Paris.

Andrews, D., C. Criscuolo and P. Gal (2016), "The Best versus the Rest: The Global Productivity Slowdown, Divergence across Firms and the Role of Public Policy", OECD Productivity Working Papers, No.5, OECD Publishing, Paris.

Andrews, D. and A. Saia (2016), "Coping with Creative Destruction: Reducing the Costs of Firm Exit", OECD Economics Department Working Papers, No. 1353, OECD Publishing, Paris.

Aoyagi, C. and G. Ganelli (2013), "The Path to Higher Growth: Does Revamping Japan's Dual Labor Market Matter?", IMF Working Paper, No. WP/13/202, International Monetary Fund, Washington, DC.

Armour, J., and D. Cumming (2008), "Bankruptcy Law and Entrepreneurship", American Law Economic Review, Vol. 10, No. 2.

Bain \& Company (2016), Corporate Governance in Japan: Board Membership and Beyond, http://www.bain.com/publications/articles/corporate-governance-in-japan-board-membership-andbeyond.aspx.

Berkowitz, J. and M. White (2004), "Bankruptcy and Small Firms' Access to Credit", RAND Journal of Economics, Vol. 35 .

Bokusheva, R. and S. Kimura (2016), "Cross-Country Comparison of Farm Size Distribution", OECD Food, Agriculture and Fisheries Papers, No. 94, OECD Publishing, Paris, http://dx.doi.org/10.1787/5jlv81sclr35-en. 
Bouis, R., R. Duval and F. Murtin (2011), "The Policy and Institutional Drivers of Economic Growth Across OECD and Non-OECD Economies: New Evidence from Growth Regressions", OECD Economics Department Working Papers, No. 843, OECD Publishing, Paris.

Caballero, R., T. Hoshi and A. Kashyap (2008), "Zombie Lending and Depressed Restructuring in Japan", American Economic Review, Vol. 98, No. 5.

Çelik, S. and M. Isaksson (2013), "Institutional Investors and Ownership Engagement", OECD Journal: Financial Market Trends, Vol. 2013/2.

Criscuolo, C., P. Gal and C. Menon (2014), "The Dynamics of Employment Growth: New Evidence from 18 Countries", CEP Discussion Paper, No. 1274, Centre for Economic Performance.

Cumming, D. (2012), "Measuring the Effect of Bankruptcy Laws on Entrepreneurship across Countries", Journal of Entrepreneurial Finance, Vol. 16.

Endo, T. (2013), "Post-crisis Regulation of Financial Institutions in Japan”, ADBI-JFSA Joint Conference, Tokyo.

European Business Council in Japan (EBC) (2014), “The Japanese Market: Why Is It Difficult? What Suppresses FDI?", Tokyo.

European Commission (2013), "Entrepreneurship in the EU and Beyond", Flash Eurobarometer, Report 354, http://ec.europa.eu/ public_opinion/flash/fl_354_en.pdf.

Expert Group of the Cabinet Office (2014), Report on the Expert Group Meeting on Foreign Direct Investment in Japan, Government of Japan.

Financial Services Agency (2017), "Status of the Stewardship Code and Opinion Statement of the Followup Council", 31 January, http://www.fsa.go.jp/en/refer/councils/stewardship/material/20170131_3.pdf.

Fukao, K. and H. Kwon (2011), "Where are the Sources of Economic Growth in Japan? Empirical Analysis Using Microdata", RIETI Discussion Paper, No. 11-J-045, Tokyo (in Japanese).

Fukao, K. (2012), The Structural Causes of Japan's "Two Lost Decades": Forging a New Growth Strategy, Nikkei Publishing Inc., Tokyo (in Japanese).

Fukao, K. (2013), "Explaining Japan's Unproductive Two Decades," Asian Economic Policy Review, Vol. 8(2), Japan Center for Economic Research, Tokyo.

Fukao, K. et al. (2015), “Why Was Japan Left Behind in the ICT Revolution?" RIETI Discussion Paper Series, 15-E-043, Tokyo.

Global Entrepreneurship Monitor (2015), Global Entrepreneurship Monitor 2014 Global Report, http://www.gemconsortium.org/report/49079.

Government Pension Investment Fund (2016), "Summary Report of Listed Companies' Survey about Institutional Investors' Stewardship Activities", 7 April, http://www.gpif.go.jp/en/topics/pdf/20160407_summary_report_of_stewardship_activities_en.pdf.

Hart, O. (2000), “Different Approaches to Bankruptcy”, NBER Working Paper Series, No. 7921.

Higuchi, Y. (2013), “The Dynamics of Poverty and the Promotion of Transition from Non-Regular to Regular Employment in Japan: Economic Effects of Minimum Wage Revision and Job Training Support", Japanese Economic Review, Vol. 64, No. 2.

Hogan, G. (2015), "Japan's Stewardship Code", Investopedia, 25 June, http://www.investopedia.com/articles/investing/062515/japans-stewardship-code.asp. 
International Monetary Fund (2012), "Japan: Financial Sector Assessment Program - Technical Note on Credit Intermediation", IMF Country Report No. 12/262, September, Washington, DC.

Investor Impact (2014), “Japan's Stewardship Code: Implications for Investor Relations", http://investorimpact.com/wp/wp-content/uploads/2014/07/IR-Insight-July_E.pdf.

Isaksson, M. (2015), "The Purpose of the OECD Principles: Economic Growth, Investment and Value Creation", My Vision, No. 8, National Institute for Research Advancement, Tokyo.

Isaksson, M. and S. Çelik (2013), "Who Cares? Corporate Governance in Today's Equity Markets", OECD Corporate Governance Working Papers, No. 8, OECD Publishing, Paris.

JETRO (2016), Investing in Japan, Tokyo, https://www.jetro.go.jp/en/invest/setting_up/laws/section4/page8.html.

Jones, R. and K. Fukawa (2017), "Ensuring Fiscal Sustainability in Japan in the Context of a Shrinking and Ageing Population", OECD Economics Department Working Papers (forthcoming), OECD Publishing, Paris.

Jones, R. and M. Kim (2014), "Promoting the Financing of SMEs and Start-ups in Korea", OECD Economics Department Working Papers, No. 1162, OECD Publishing, Paris, http://dx.doi.org/10.1787/5jxx054bdlvh-en.

Jones, R. and M. Kim (2015), "Enhancing Dynamism and Innovation in Japan's Business Sector", OECD Economics Department Working Papers, No. 1261, OECD Publishing, Paris, http://dx.doi.org/10.1787/5jrtpbtkbhs1-en.

Jones, R. and S. Kimura (2013), "Reforming Agriculture and Promoting Japan's Integration in the World Economy”, OECD Economics Department Working Papers, No. 1053, OECD Publishing, Paris, http://dx.doi.org/10.1787/5k46957l0rf4-en.

Kanda, H. (2013), "Corporate Governance in Japan and a Comparative Perspective", presentation at UC Hastings College of Law, 18 October.

Koske, I., I. Wanner, R. Bitetti and O. Barbiero (2015), "The 2013 Update of the OECD Product Market Regulation Indicators: Policy Insights for OECD and non-OECD Countries", OECD Economics Department Working Papers, No. 1200, OECD Publishing, Paris.

Lam, W. and J. Shin (2012), "What Role Can Financial Policies Play in Revitalizing SMEs in Japan?", IMF Working Papers, WP/12/291, International Monetary Fund, Washington, DC.

Marinc, M. and R. Vlahu (2012), The Economics of Bank Bankruptcy Law, Springer-Verlag, Berlin Heidelberg.

Martin, J. and S. Scarpetta (2012), "Setting it Right: Employment Protection, Labour Reallocation and Productivity", De Economist, 160.

Ministry of Agriculture, Forestry and Fisheries (MAFF) (2015), 2015 Census of Agriculture and Forestry, Tokyo.

Ministry of Economy, Trade and Industry (2014), 2014 White Paper on Small and Medium Enterprises in Japan, Tokyo.

Ministry of Health, Labor and Welfare (2011), Comprehensive Research on Diverse Employment Formats 2010, Tokyo (in Japanese).

Ministry of Health, Labor and Welfare (2014), Annual Report on the Labor Economy, Tokyo (in Japanese).

Ministry of Health, Labor and Welfare (2015), Survey on Employment Trends 2014, Tokyo.

Minoya, A. (2012), "SME Finance in Japan: Experiences and Challenges”, presentation, Bank of Japan. 
Mitsubishi UFJ Research and Consulting (2010), Survey on the Rehabilitation of SMEs, research commissioned for the Small and Medium Enterprise Agency.

Mitsubishi UFJ Research and Consulting (2013), "Survey of Japan's Entrepreneurial Environment and Latent Entrepreneurs", research commissioned for the Small and Medium Enterprise Agency.

Motohashi, K. (2013), "Innovation Policy Challenges for Japan: An Open and Global Strategy", Asie Visions 45, IFRI Center for Asian Studies, Paris.

Nakamura, J. (2017), Japanese Firms during the Lost Two Decades: the Recovery of Zombie Firms and Entrenchment of Reputable Firms, Development Bank of Japan Research Series, Springer Briefs in Economics, Tokyo.

Nassr, I. and G. Wehinger (2016), "Opportunities and Limitations of Public Equity Markets for SMEs", OECD Journal: Financial Market Trends, Vol. 2015/1, http://dx.doi.org/10.1787/fmt-20155jrs051fvnjk.

Nomura Research Institute (2014), Interim Report to the Working Party on Business Revitalization Focusing on Business Succession, Small and Medium Enterprise Agency, Tokyo.

Odaki, K. and M. Kodama (2014), "Stakeholder-Oriented Corporate Governance and Firm-Specific Human Capital: Wage Analysis of Employer-Employee Matched Data", RIETI Discussion Paper Series 10-E-014, Tokyo, http://www.rieti.go.jp/jp/publications/dp/10e014.pdf.

OECD (2011), The Role of Institutional Investors in Promoting Good Corporate Governance, OECD Publishing, Paris.

OECD (2013a), Entrepreneurship at a Glance, OECD Publishing, Paris.

OECD (2013b), OECD Economic Survey of Japan, OECD Publishing, Paris.

OECD (2013c), OECD Skills Outlook 2013: First Results from the Survey of Adult Skills, OECD Publishing, Paris, http://dx.doi.org/10.1787/9789264204256-en.

OECD (2015a), Back to Work: Japan: Improving the Re-employment Prospects of Displaced Workers, OECD Publishing, Paris, http://dx.doi.org/10.1787/9789264227200-en.

OECD (2015b), Digital Economy Outlook, OECD Publishing, Paris.

OECD (2015c), Future of Productivity, OECD Publishing, Paris.

OECD (2015d), OECD Economic Survey of Japan, OECD Publishing, Paris.

OECD (2015e), OECD Innovation Strategy 2015: An Agenda for Policy Action, Meeting of the OECD Council at Ministerial Level, http://www.oecd.org/innovation/OECD-Innovation-Strategy-2015CMIN2015-7.pdf.

OECD (2015f), Opportunities and Constraints of Market-based Financing for SMEs, OECD report to G20 Finance Ministers and Central Bank Governors, September, http://www.oecd.org/finance/financialmarkets/Opportunities-and-Constraints-of-Market-based-Financing-for-SMEs.pdf.

OECD (2015g), Students, Computers and Learning: Making the Connection, OECD Publishing, Paris, http://dx.doi.org/10.1787/888933277865).

OECD (2016a), Agricultural Policy and Monitoring, OECD Publishing, Paris.

OECD (2016b), Entrepreneurship at a Glance, OECD Publishing, Paris.

OECD (2016c), Financing SMEs and Entrepreneurs 2016: An OECD Scoreboard, OECD Publishing, Paris. 
OECD (2016d), Japan: Boosting Growth and Well-being in an Ageing Society, http://www.oecdlibrary.org/docserver/download/0316051e.pdf?expires $=1486717482 \& i d=i d \&$ accname $=$ guest\&chec ksum $=804$ A91714BAOAFD4195A03569C154885.

OECD (2016e), OECD Economic Survey of Korea, OECD Publishing, Paris.

OECD (2016f), OECD Employment Outlook, OECD Publishing, Paris.

OECD (2016g), OECD Science, Technology and Innovation Outlook: Country Profile, OECD Publishing, Paris.

OECD (2016h), PISA 2015 Results (Volume I): Excellence and Equity in Education, PISA, OECD Publishing, Paris. http://dx.doi.org/10.1787/9789264266490-en.

OECD (2016i), "Promoting Productivity and Equality: Twin Challenges", OECD Economic Outlook No. 99, OECD Publishing, Paris.

OECD (2016j), The Productivity-Inclusiveness Nexus, Meeting at the OECD Council at Ministerial Level, 1-2 June, Paris, http://www.oecd.org/global-forum-productivity/library/The-ProductivityInclusiveness-Nexus-Preliminary.pdf.

OECD (2017a), Financing SMEs and Entrepreneurs 2017: An OECD Scoreboard, OECD Publishing, Paris.

OECD (2017b), OECD Economic Outlook: Statistics and Projections (database), OECD, Paris.

OECD (2017c), OECD Economic Survey of Italy, OECD Publishing, Paris.

OECD (2017d), OECD Economic Survey of Japan, OECD Publishing, Paris.

OECD (2017e), OECD International Direct Investment Statistics (database), OECD, Paris.

OECD (2017f), OECD Product Market Regulation Statistics (database), OECD, Paris.

OECD (2017g), OECD Productivity Statistics (database), OECD, Paris.

OECD (2017h), OECD Science, Technology and R\&D Statistics (database), OECD, Paris.

OECD (2017i), "The Great Divergence(s): The Link Between Growing Productivity Dispersion and Wage Inequality”, Directorate for Science, Technology and Innovation Policy Note, May.

Ono, A. and L. Uesugi (2014), "SME Financing in Japan during the Global Financial Crisis: Evidence from Firm Surveys", Institute of Economic Research, Hitotsubashi University, Tokyo.

Oshio, T. (2013), Economics of Social Security, Nippon Hyoron Sha, Tokyo (in Japanese).

Persad, S. (2004), "Bankruptcy Exemptions and Small Business Credit Re-examined: Using Loan Guarantees to Isolate Borrower Moral Hazard Behavior", Working Paper, Columbia University.

Prime Minister's Office (2016), "Press Conference by Prime Minister Shinzo Abe", 3 August, http://japan.kantei.go.jp/97_abe/statement/201608/1218775_11013.html.

Saito, T. (2009), “Why Outside Directors in Japan are Not Prevalent?”, RIETI Report, No. 110, Tokyo.

Scarpetta S. and A. Wyckoff (2016), "Digitalisation and Future of Work, Introductory Remarks", Meeting of the OECD Global Parliamentary Network, October.

Schwellnus, C., A. Kappeler and P-A. Pionnier (2017), "Decoupling of Wages from Productivity: Macrolevel Facts", OECD Economics Department Working Papers, No. 1373, OECD Publishing, Paris.

Small and Medium Enterprise Agency (2014), Japan's Policies for Small and Medium Enterprises, Tokyo.

Small and Medium Enterprise Agency (2016), 2016 White Paper on Small and Medium Enterprises in Japan, Tokyo. 
Smith, D. and K. Chern-Yeh (2016), "Corporate Governance in Japan: A Work in Progress", Institutional Investor (4 July), http://www.institutionalinvestor.com/blogarticle/3567253/blog/corporategovernance-in-japan-a-work-in-progress.html\#.V-zw7fl97IU.

Smith, D. and P. Strömberg (2005), "Maximizing the Value of Distressed Assets: Bankruptcy Law and the Efficient Reorganization of Firms", in L. Laeven and P. Honohan (ed.) Systemic Financial Crises: Containment and Resolution, Cambridge University Press.

Solomon, R. (2016), "Enough Already! Why Japan Needs no more Venture Capital”, Beacon Reports, 13 November, Tokyo.

Strategic Headquarters for the Promotion of an Advanced Information and Telecommunications Network Society (2013), Declaration to be the World's Most Advanced IT Nation, Government of Japan, http://japan.kantei.go.jp/policy/it/2013/0614_declaration.pdf.

Teikoku Data Bank (2016), Bankruptcy Data 2015, Tokyo (in Japanese).

Tokyo Stock Exchange (2016), "How Listed Companies Have Addressed Japan's Corporate Governance Code", 13 September, http://www.jpx.co.jp/english/news/1020/b5b4pj000001a0y8-att/201609132.pdf.

Tsuru, K. (2012), "Future Course of Fixed-term Employment Reform: An Assessment of the Report of the Labor Policy Council's Subcommittee", Research Institute of Economy, Trade and Institute.

Tsuruta, D. (2016), "SME Policies as a Barrier to Growth of SMEs", Paper prepared as part of the project "Study on Corporate Finance and Firm Dynamics" at the Research Institute of Economy, Trade, and Industry (RIETI).

Ueda, R. (2015), "How is Corporate Governance in Japan Changing? Developments in Listed Companies and Roles of Institutional Investors", OECD Corporate Governance Working Papers, No. 17, OECD Publishing, Paris, http://dx.doi.org/10.1787/5jrw7j3s37hh-en.

Uesugi, I. (2010), The Impact of International Financial Crises on SMEs: The Case of Japan, Hitotsubashi University, May.

Westmore, B. (2013), "R\&D, Patenting and Growth: The Role of Public Policy", OECD Economics Department Working Papers, No. 1047, OECD Publishing, Paris.

World Bank (2017), Doing Business 2017: Equal Opportunity for All, Washington, DC.

World Economic Forum (2017), Global Competitiveness Report 2016-2017, http://www3.weforum.org/docs/GCR2016-

2017/05FullReport/TheGlobalCompetitivenessReport2016-2017_FINAL.pdf.

Yamada Business Consulting (2011), FY 2010 Financial Institutions Survey on the Personal Guarantee System and Rehabilitation, research commissioned for the Small and Medium Enterprise Agency.

Yamori, N., K. Kondo, K. Tomimura, Y. Shindo and K. Takaku (2013), "Japanese Banking Regulations and SME Finance under the Global Financial Crisis", Japanese Journal of Monetary and Financial Economics, Vol. 1.

Yamori, N. (2014), "Japanese SMEs and the Credit Guarantee System after the Global Financial Crisis", Research Institute for Economics and Business Administration Discussion Paper Series, DP2014-26, Kobe.

Yashiro, N. (2016), "Regulatory Coherence: The Case of Japan", in D. Gill and P. Intal, Jr. (eds.), The Development of Regulatory Management Systems in East Asia: Country Studies, ERIA Research Project Report 2015-4, Jakarta, ERIA. 